\title{
Prophylactic oxytocin for the third stage of labour (Review)
}

\author{
Cotter AM, Ness A, Tolosa JE
}

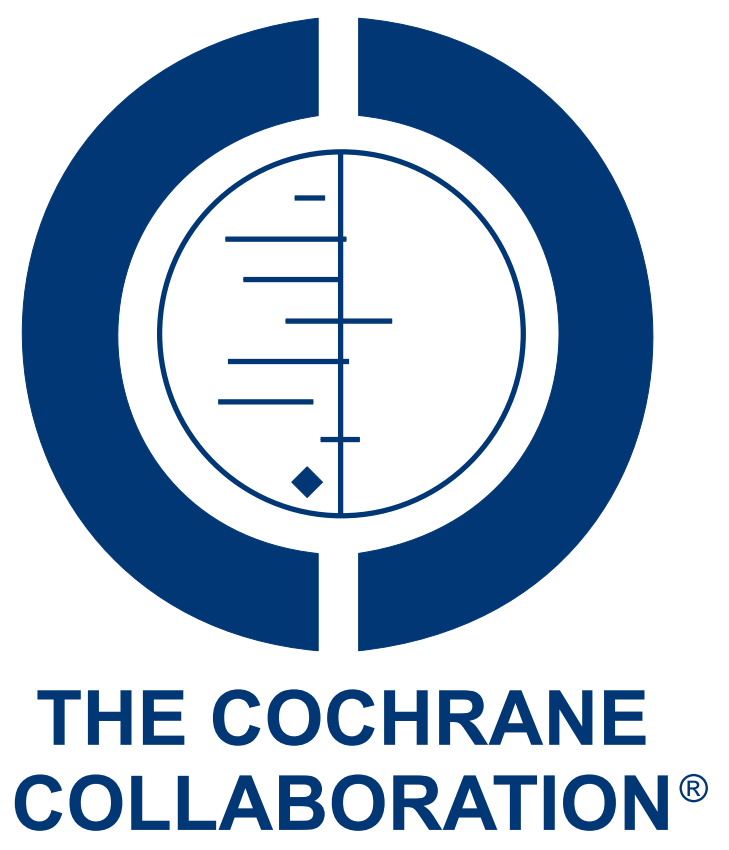

This is a reprint of a Cochrane review, prepared and maintained by The Cochrane Collaboration and published in The Cochrane Library 2001, Issue 4

http://www.thecochranelibrary.com

\section{WILEY}

Prophylactic oxytocin for the third stage of labour (Review)

Copyright $\odot 2010$ The Cochrane Collaboration. Published by John Wiley \& Sons, Ltd. 
TABLE OF CONTENTS

HEADER . . . . . . . . . . . . . . . . . . . . . . . . . . . . . . . . . . . . . . . . . . . . . . . . . . . . . .

ABSTRACT . . . . . . . . . . . . . . . . . . . . . . . . . . . . . . . . . . . . . . . . . . . . . . . . . . . . .

PLAIN LANGUAGE SUMMARY . . . . . . . . . . . . . . . . . . . . . . . . . . . . . . . . . . . . . . . . . . .

BACKGROUND . . . . . . . . . . . . . . . . . . . . . . . . . . . . . . . . . . . . . 2

OBJECTIVES . . . . . . . . . . . . . . . . . . . . . . . . . . . . . . . . . . . . . . . . . . . . . . . .

METHODS . . . . . . . . . . . . . . . . . . . . . . . . . . . . . . . . . . . . . . . 3

RESULTS . . . . . . . . . . . . . . . . . . . . . . . . . . . . . . . . . . . . . . . . . 5

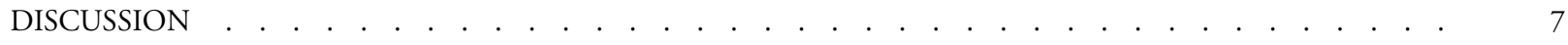

AUTHORS' CONCLUSIONS . . . . . . . . . . . . . . . . . . . . . . . . . . . . . . . . . . . . . . . . .

ACKNOWLEDGEMENTS . . . . . . . . . . . . . . . . . . . . . . . . . . . . . . . . . . . . . . . . . . . . . .

REFERENCES . . . . . . . . . . . . . . . . . . . . . . . . . . . . . . . . . . . . . . 8

CHARACTERISTICS OF STUDIES . . . . . . . . . . . . . . . . . . . . . . . . . . . . . . . . . . . . . . . . . . .

DATA AND ANALYSES . . . . . . . . . . . . . . . . . . . . . . . . . . . . . . . . . . . . . . . . . . . . . . . . . . . . . . .

Analysis 1.1. Comparison 1 Oxytocin versus no uterotonics (all trials), Outcome $1 \mathrm{PPH}$ (clinically estimated blood loss >

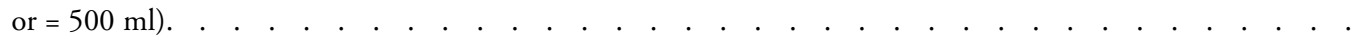

Analysis 1.2. Comparison 1 Oxytocin versus no uterotonics (all trials), Outcome 2 Severe PPH (clinically estimated blood loss $>$ or $=1000 \mathrm{ml}$ )

Analysis 1.3. Comparison 1 Oxytocin versus no uterotonics (all trials), Outcome 3 Mean blood loss (ml).

Analysis 1.4. Comparison 1 Oxytocin versus no uterotonics (all trials), Outcome 4 Maternal haemoglobin concentration $(\mathrm{Hb})<9$ gm/deciltre 24 to 48 hours postpartum. . . . . . . . . . . . . . . . . . . . . . . . . . . . . . . . 31

Analysis 1.5. Comparison 1 Oxytocin versus no uterotonics (all trials), Outcome 5 Blood transfusion. . . . . . 32

Analysis 1.7. Comparison 1 Oxytocin versus no uterotonics (all trials), Outcome 7 Therapeutic uterontonics. . . . . 33

Analysis 1.10. Comparison 1 Oxytocin versus no uterotonics (all trials), Outcome 10 Mean length of third stage (minutes).

Analysis 1.11. Comparison 1 Oxytocin versus no uterotonics (all trials), Outcome 11 Manual removal of the placenta.

Analysis 1.15. Comparison 1 Oxytocin versus no uterotonics (all trials), Outcome 15 Nausea between delivery of the baby and discharge from the labour ward.

Analysis 2.1. Comparison 2 Oxytocin versus no uterotonics (randomised trials only), Outcome $1 \mathrm{PPH}$ (clinically estimated blood loss $>$ or $=500 \mathrm{ml}$ ).

Analysis 2.2. Comparison 2 Oxytocin versus no uterotonics (randomised trials only), Outcome 2 Severe PPH (clinically estimated blood loss $>$ or $=1000 \mathrm{ml}$ ).

Analysis 2.3. Comparison 2 Oxytocin versus no uterotonics (randomised trials only), Outcome 3 Mean blood loss ( $\mathrm{ml}$ ).

Analysis 2.4. Comparison 2 Oxytocin versus no uterotonics (randomised trials only), Outcome 4 Maternal haemoglobin concentration $(\mathrm{Hb})<9 \mathrm{gm} /$ deciltre 24 to 48 hours postpartum.

Analysis 2.5. Comparison 2 Oxytocin versus no uterotonics (randomised trials only), Outcome 5 Blood transfusion.

Analysis 2.7. Comparison 2 Oxytocin versus no uterotonics (randomised trials only), Outcome 7 Therapeutic uterontonics. . . . . . . . . . . . . . . . . . . . . . . . . . . . . . . . . . .

Analysis 2.10. Comparison 2 Oxytocin versus no uterotonics (randomised trials only), Outcome 10 Mean length of third stage (minutes).

Analysis 2.11. Comparison 2 Oxytocin versus no uterotonics (randomised trials only), Outcome 11 Manual removal of the placenta.

Analysis 2.15. Comparison 2 Oxytocin versus no uterotonics (randomised trials only), Outcome 15 Nausea between delivery of the baby and discharge from the labour ward.

Analysis 3.1. Comparison 3 Oxytocin versus no uterotonics (active management only), Outcome $1 \mathrm{PPH}$ (clinically estimated blood loss $>$ or $=500 \mathrm{ml}$ ).

Analysis 3.2. Comparison 3 Oxytocin versus no uterotonics (active management only), Outcome 2 Severe PPH (clinically estimated blood loss $>$ or $=1000 \mathrm{ml}$ ).

Analysis 3.11. Comparison 3 Oxytocin versus no uterotonics (active management only), Outcome 11 Manual removal of the placenta.

Analysis 4.1. Comparison 4 Oxytocin versus no uterotonics (expectant management only), Outcome $1 \mathrm{PPH}$ (clinically estimated blood loss $>$ or $=500 \mathrm{ml})$. 
Analysis 4.2. Comparison 4 Oxytocin versus no uterotonics (expectant management only), Outcome 2 Severe PPH (clinically estimated blood loss $>$ or $=1000 \mathrm{ml}$ ).

Analysis 4.3. Comparison 4 Oxytocin versus no uterotonics (expectant management only), Outcome 3 Mean blood loss $(\mathrm{ml})$.

Analysis 4.4. Comparison 4 Oxytocin versus no uterotonics (expectant management only), Outcome 4 Maternal haemoglobin concentration $(\mathrm{Hb})<9 \mathrm{gm} /$ deciltre 24 to 48 hours postpartum. . . . . . . . . . . . . . .

Analysis 4.5. Comparison 4 Oxytocin versus no uterotonics (expectant management only), Outcome 5 Blood transfusion.

Analysis 4.7. Comparison 4 Oxytocin versus no uterotonics (expectant management only), Outcome 7 Therapeutic uterontonics. . . . . . . . . . . . . . . . . . . . . . . . . . . . . . . . . . .

Analysis 4.11. Comparison 4 Oxytocin versus no uterotonics (expectant management only), Outcome 11 Manual removal of the placenta.

Analysis 5.1. Comparison 5 Oxytocin versus no uterotonics (given before placental delivery), Outcome $1 \mathrm{PPH}$ (clinically estimated blood loss $>$ or $=500 \mathrm{ml})$.

Analysis 5.2. Comparison 5 Oxytocin versus no uterotonics (given before placental delivery), Outcome $2 \mathrm{Severe} \mathrm{PPH}$ (clinically estimated blood loss $>$ or $=1000 \mathrm{ml}$ ).

Analysis 5.3. Comparison 5 Oxytocin versus no uterotonics (given before placental delivery), Outcome 3 Mean blood loss $(\mathrm{ml})$.

Analysis 5.4. Comparison 5 Oxytocin versus no uterotonics (given before placental delivery), Outcome 4 Maternal haemoglobin concentration $(\mathrm{Hb})<9 \mathrm{gm} /$ deciltre 24 to 48 hours postpartum. . . . . . . . . . . . . . . .

Analysis 5.5. Comparison 5 Oxytocin versus no uterotonics (given before placental delivery), Outcome 5 Blood transfusion.

Analysis 5.7. Comparison 5 Oxytocin versus no uterotonics (given before placental delivery), Outcome 7 Therapeutic uterontonics. . . . . . . . . . . . . . . . . . . . . . . . . . . . . . . . . . . .

Analysis 5.10. Comparison 5 Oxytocin versus no uterotonics (given before placental delivery), Outcome 10 Mean length of third stage (minutes).

Analysis 5.11. Comparison 5 Oxytocin versus no uterotonics (given before placental delivery), Outcome 11 Manual removal of the placenta. . . . . . . . . . . . . . . . . . . . . . . . . . . . . . . . . .

Analysis 5.15. Comparison 5 Oxytocin versus no uterotonics (given before placental delivery), Outcome 15 Nausea between delivery of the baby and discharge from the labour ward. . . . . . . . . . . . . . . . . . . . . . .

Analysis 6.1. Comparison 6 Oxytocin versus no uterotonics (given after placental delivery), Outcome $1 \mathrm{PPH}$ (clinically estimated blood loss $>$ or $=500 \mathrm{ml})$.

Analysis 6.3. Comparison 6 Oxytocin versus no uterotonics (given after placental delivery), Outcome 3 Mean blood loss $(\mathrm{ml})$.

Analysis 6.7. Comparison 6 Oxytocin versus no uterotonics (given after placental delivery), Outcome 7 Therapeutic uterontonics.

Analysis 7.1. Comparison 7 Oxytocin versus ergot alkaloids (all trials), Outcome $1 \mathrm{PPH}$ (clinically estimated blood loss > or $=500 \mathrm{ml}$ ). . . . . . . . . . . . . . . . . . . . . . . . . . . . . . . . . . . . . . . . . . .

Analysis 7.2. Comparison 7 Oxytocin versus ergot alkaloids (all trials), Outcome 2 Severe PPH (clinically estimated blood loss $>$ or $=1000 \mathrm{ml})$.

Analysis 7.3. Comparison 7 Oxytocin versus ergot alkaloids (all trials), Outcome 3 Mean blood loss (ml). 56

Analysis 7.5. Comparison 7 Oxytocin versus ergot alkaloids (all trials), Outcome 5 Blood transfusion. $\quad . \quad . \quad . \quad . \quad . \quad . \quad 567$

Analysis 7.7. Comparison 7 Oxytocin versus ergot alkaloids (all trials), Outcome 7 Therapeutic uterontonics. . . . 58

Analysis 7.8. Comparison 7 Oxytocin versus ergot alkaloids (all trials), Outcome 8 Third stage $>20$ minutes. . . . 58

Analysis 7.9. Comparison 7 Oxytocin versus ergot alkaloids (all trials), Outcome 9 Third stage $>40$ minutes. . . . 59

Analysis 7.10. Comparison 7 Oxytocin versus ergot alkaloids (all trials), Outcome 10 Mean length of third stage (minutes).

Analysis 7.11. Comparison 7 Oxytocin versus ergot alkaloids (all trials), Outcome 11 Manual removal of the placenta.

Analysis 7.13. Comparison 7 Oxytocin versus ergot alkaloids (all trials), Outcome 13 Diastolic blood pressure $>100 \mathrm{~mm}$ $\mathrm{Hg}$ between delivery of the baby and discharge from the labour ward.

Analysis 8.1. Comparison 8 Oxytocin versus ergot alkaloids (randomised trials only), Outcome 1 PPH (clinically estimated blood loss $>$ or $=500 \mathrm{ml}$ ).

Analysis 8.2. Comparison 8 Oxytocin versus ergot alkaloids (randomised trials only), Outcome 2 Severe PPH (clinically estimated blood loss $>$ or $=1000 \mathrm{ml})$. 
Analysis 8.3. Comparison 8 Oxytocin versus ergot alkaloids (randomised trials only), Outcome 3 Mean blood loss (ml).

Analysis 8.5. Comparison 8 Oxytocin versus ergot alkaloids (randomised trials only), Outcome 5 Blood transfusion.

Analysis 8.7. Comparison 8 Oxytocin versus ergot alkaloids (randomised trials only), Outcome 7 Therapeutic uterontonics.

Analysis 8.8. Comparison 8 Oxytocin versus ergot alkaloids (randomised trials only), Outcome 8 Third stage $>20$ minutes.

Analysis 8.9. Comparison 8 Oxytocin versus ergot alkaloids (randomised trials only), Outcome 9 Third stage $>40$ minutes.

Analysis 8.11. Comparison 8 Oxytocin versus ergot alkaloids (randomised trials only), Outcome 11 Manual removal of the placenta.

Analysis 10.1. Comparison 10 Oxytocin versus ergot alkaloids (expectant management only), Outcome $1 \mathrm{PPH}$ (clinically estimated blood loss $>$ or $=500 \mathrm{ml}$ ).

Analysis 10.2. Comparison 10 Oxytocin versus ergot alkaloids (expectant management only), Outcome 2 Severe PPH (clinically estimated blood loss $>$ or $=1000 \mathrm{ml}$ ).

Analysis 10.3. Comparison 10 Oxytocin versus ergot alkaloids (expectant management only), Outcome 3 Mean blood loss $(\mathrm{ml})$

Analysis 10.5. Comparison 10 Oxytocin versus ergot alkaloids (expectant management only), Outcome 5 Blood transfusion.

Analysis 10.7. Comparison 10 Oxytocin versus ergot alkaloids (expectant management only), Outcome 7 Therapeutic uterontonics.

Analysis 10.11. Comparison 10 Oxytocin versus ergot alkaloids (expectant management only), Outcome 11 Manual removal of the placenta.

Analysis 11.1. Comparison 11 Oxytocin versus ergot alkaloids (given before placental delivery), Outcome $1 \mathrm{PPH}$ (clinically estimated blood loss $>$ or $=500 \mathrm{ml}$ ).

Analysis 11.2. Comparison 11 Oxytocin versus ergot alkaloids (given before placental delivery), Outcome $2 \mathrm{Severe} \mathrm{PPH}$ (clinically estimated blood loss $>$ or $=1000 \mathrm{ml}$ ).

Analysis 11.3. Comparison 11 Oxytocin versus ergot alkaloids (given before placental delivery), Outcome 3 Mean blood loss (ml).

Analysis 11.5. Comparison 11 Oxytocin versus ergot alkaloids (given before placental delivery), Outcome 5 Blood transfusion.

Analysis 11.7. Comparison 11 Oxytocin versus ergot alkaloids (given before placental delivery), Outcome 7 Therapeutic uterontonics.

Analysis 11.8. Comparison 11 Oxytocin versus ergot alkaloids (given before placental delivery), Outcome 8 Third stage > 20 minutes.

Analysis 11.9. Comparison 11 Oxytocin versus ergot alkaloids (given before placental delivery), Outcome 9 Third stage > 40 minutes.

Analysis 11.10. Comparison 11 Oxytocin versus ergot alkaloids (given before placental delivery), Outcome 10 Mean length of third stage (minutes).

Analysis 11.11. Comparison 11 Oxytocin versus ergot alkaloids (given before placental delivery), Outcome 11 Manual removal of the placenta.

Analysis 11.13. Comparison 11 Oxytocin versus ergot alkaloids (given before placental delivery), Outcome 13 Diastolic blood pressure $>100 \mathrm{~mm} \mathrm{Hg}$ between delivery of the baby and discharge from the labour ward.

Analysis 12.1. Comparison 12 Oxytocin versus ergot alkaloids (given after placental delivery), Outcome 1 PPH (clinically estimated blood loss $>$ or $=500 \mathrm{ml}$ ).

Analysis 12.7. Comparison 12 Oxytocin versus ergot alkaloids (given after placental delivery), Outcome 7 Therapeutic uterontonics.

Analysis 13.1. Comparison 13 Oxytocin + ergometrine versus ergot alkaloids alone (all trials), Outcome $1 \mathrm{PPH}$ (clinically estimated blood loss $>$ or $=500 \mathrm{ml}$ ).

Analysis 13.2. Comparison 13 Oxytocin + ergometrine versus ergot alkaloids alone (all trials), Outcome 2 Severe PPH (clinically estimated blood loss $>$ or $=1000 \mathrm{ml}$ ).

Analysis 13.5. Comparison 13 Oxytocin + ergometrine versus ergot alkaloids alone (all trials), Outcome 5 Blood transfusion.

Prophylactic oxytocin for the third stage of labour (Review)

Copyright $\odot 2010$ The Cochrane Collaboration. Published by John Wiley \& Sons, Ltd. 
Analysis 13.8. Comparison 13 Oxytocin + ergometrine versus ergot alkaloids alone (all trials), Outcome 8 Third stage $>20$ minutes.

Analysis 13.11. Comparison 13 Oxytocin + ergometrine versus ergot alkaloids alone (all trials), Outcome 11 Manual removal of the placenta.

Analysis 14.1. Comparison 14 Oxytocin + ergometrine versus ergot alkaloids alone (randomised trials), Outcome $1 \mathrm{PPH}$ (clinically estimated blood loss $>$ or $=500 \mathrm{ml}$ ).

Analysis 14.8. Comparison 14 Oxytocin + ergometrine versus ergot alkaloids alone (randomised trials), Outcome 8 Third stage $>20$ minutes. . . . . . . . . . . . . . . . . . . . . . . . . . . . . . . . . . . . . . . . .

Analysis 15.1. Comparison 15 Oxytocin + ergometrine versus ergot alkaloids alone (active management), Outcome $1 \mathrm{PPH}$ (clinically estimated blood loss $>$ or $=500 \mathrm{ml}$ ).

Analysis 15.8. Comparison 15 Oxytocin + ergometrine versus ergot alkaloids alone (active management), Outcome 8 Third stage $>20$ minutes. . . . . . . . . . . . . . . . . . . . . . . . . . . . . . . . . . . . . . . . . . . .

Analysis 15.11. Comparison 15 Oxytocin + ergometrine versus ergot alkaloids alone (active management), Outcome 11 Manual removal of the placenta. . . . . . . . . . . . . . . . . . . . . . . . . . . . . . . . . . . .

Analysis 17.1. Comparison 17 Oxytocin + ergometrine versus ergot alkaloids alone (given before placental delivery, Outcome $1 \mathrm{PPH}$ (clinically estimated blood loss $>$ or $=500 \mathrm{ml}$ ).

Analysis 17.2. Comparison 17 Oxytocin + ergometrine versus ergot alkaloids alone (given before placental delivery, Outcome 2 Severe PPH (clinically estimated blood loss $>$ or $=1000 \mathrm{ml}$ ). $\quad . \quad$. . . . . . . . . . . . . . . .

Analysis 17.5. Comparison 17 Oxytocin + ergometrine versus ergot alkaloids alone (given before placental delivery, Outcome 5 Blood transfusion. . . . . . . . . . . . . . . . . . . . . . . . . . . . . .

Analysis 17.8. Comparison 17 Oxytocin + ergometrine versus ergot alkaloids alone (given before placental delivery, Outcome 8 Third stage $>20$ minutes.

Analysis 17.11. Comparison 17 Oxytocin + ergometrine versus ergot alkaloids alone (given before placental delivery, Outcome 11 Manual removal of the placenta. . . . . . . . . . . . . . . . . . . . . . . .

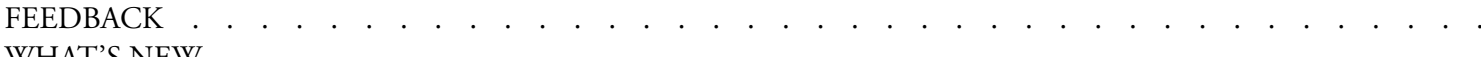

WHAT'S NEW . . . . . . . . . . . . . . . . . . . . . . . . . . . . . . . . . . . . .

HISTORY

CONTRIBUTIONS OF AUTHORS . . . . . . . . . . . . . . . . . . . . . . . . . . . . . . . . .

DECLARATIONS OF INTEREST . . . . . . . . . . . . . . . . . . . . . . . . . . . . . .

NOTES . . . . . . . . . . . . . . . . . . . . . . . . . . . . . . . . . . . . . . . .

INDEX TERMS

Prophylactic oxytocin for the third stage of labour (Review) 


\title{
[Intervention Review]
}

\section{Prophylactic oxytocin for the third stage of labour}

\author{
Amanda M Cotter ${ }^{1}$, Amen Ness ${ }^{2}$, Jorge E Tolosa ${ }^{3}$ \\ ${ }^{1}$ Department of Obstetrics and Gynecology, University of Miami, Miami, Florida, USA. ${ }^{2}$ Department of Obstetrics and Gynecology, \\ Thomas Jefferson University, Philadelphia, USA. ${ }^{3}$ Department of Obstetrics and Gynecology, Oregon Health and Sciences University, \\ Portland, Oregon, USA \\ Contact address: Amanda M Cotter, Department of Obstetrics and Gynecology, University of Miami, PO Box 016960 (D-53), Miami, \\ Florida, 33101, USA. acotter@med.miami.edu.
}

Editorial group: Cochrane Pregnancy and Childbirth Group.

Publication status and date: Edited (no change to conclusions), published in Issue 2, 2010.

Review content assessed as up-to-date: 30 November 2004.

Citation: Cotter AM, Ness A, Tolosa JE. Prophylactic oxytocin for the third stage of labour. Cochrane Database of Systematic Reviews 2001, Issue 4. Art. No.: CD001808. DOI: 10.1002/14651858.CD001808.

Copyright (C) 2010 The Cochrane Collaboration. Published by John Wiley \& Sons, Ltd.

\section{A B S T R A C T}

\section{Background}

Complications of the third stage of labour are a significant cause of maternal mortality worldwide.

\section{Objectives}

To examine the effect of oxytocin given prophylactically in the third stage of labour on maternal and neonatal outcomes.

\section{Search methods}

We searched the Cochrane Pregnancy and Childbirth Group's Trials Register (December 2004). We updated this search on 1 October 2009 and added the results to the awaiting classification section.

\section{Selection criteria}

Randomised or quasi-randomised controlled trials including pregnant women anticipating a vaginal delivery where oxytocin was given prophylactically for the third stage of labour.

\section{Data collection and analysis}

The review authors independently assessed trial quality and extracted data. Analysis was by intention to treat. Subgroup analyses were based on extent of selection bias, oxytocin in the context of active or expectant management of the third stage, and timing of administration. Results are presented as relative risks, and weighted mean difference, both with $95 \%$ confidence intervals using a fixedeffect model.

\section{Main results}

Fourteen trials are included.

In seven trials involving over 3000 women, prophylactic oxytocin showed benefits (reduced blood loss (relative risk (RR) for blood loss

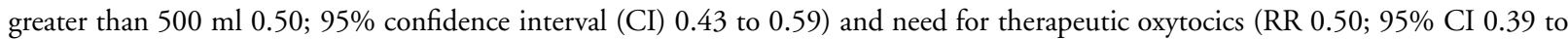
0.64) compared to no uterotonics.

Prophylactic oxytocin for the third stage of labour (Review)

Copyright @ 2010 The Cochrane Collaboration. Published by John Wiley \& Sons, Ltd. 
In six trials involving over 2800 women, there was little evidence of differential effects for oxytocin versus ergot alkaloids, except that oxytocin was associated with fewer manual removals of the placenta (RR 0.57 ; 95\% CI 0.41 to 0.79 ), and with the suggestion of less raised blood pressure (RR $0.53 ; 95 \%$ CI 0.19 to 1.52 ) than with ergot alkaloids.

In five trials involving over 2800 women, there was little evidence of a synergistic effect of adding oxytocin to ergometrine versus ergometrine alone.

\section{Authors' conclusions}

Oxytocin appears to be beneficial for the prevention of postpartum haemorrhage. However, there is insufficient information about other outcomes and side-effects hence it is difficult to be confident about the trade-offs for these benefits. There seems little evidence in favour of ergot alkaloids alone compared to either oxytocin alone, or to ergometrine-oxytocin, but the data are sparse. More trials are needed in domiciliary deliveries in developing countries, which shoulder most of the burden of third stage complications.

[Note: The ten citations in the awaiting classification section of the review may alter the conclusions of the review once assessed.]

\section{PLAIN LANGUAGE SUMMARY}

\section{Prophylactic oxytocin for the third stage of labour}

Oxytocin used routinely after birth can reduce blood loss, but more research is needed on possible adverse effects.

The third stage of labour is that period from birth of the baby until delivery of the placenta. The degree of blood loss depends on how quickly the placenta separates from the uterine wall and the uterine muscle contracts. Severe blood loss - postpartum haemorrhage, is a major problem, particularly where there is poor nutrition and lack of access to treatment. The review of trials found routine use of oxytocin, a drug which helps the uterus contract, may reduce the amount of blood loss, but there is not enough evidence about adverse effects. More research is needed.

\section{B A C K G R O U N D}

The most reliable estimates of global mortality for mothers in childbirth are reported as between 500,000 and 600,000 annually (UNICEF 1996; WHO 1990). Many of these deaths result from complications of the third stage of labour.

The third stage of labour is that period from delivery of the baby until delivery of the placenta. After delivery of the baby and cessation of umbilical cord pulsation the placenta separates from the uterine wall through the spongy lining of the womb (decidua spongiosa) and is delivered through the birth canal. The placenta separates as a result of capillary haemorrhage and the shearing effect of uterine muscle contraction. The degree of blood loss associated with placental separation and delivery depends on how quickly the placenta separates from the uterine wall and how effectively uterine muscle contracts around the placental bed (where the placenta is attached to the wall of the uterus), and the blood vessels, during and after separation, and expels the placenta through the birth canal.
Moderate loss of blood is physiological and unlikely to lead to later problems except for women who are already anaemic. The major complication associated with this stage is postpartum haemorrhage (PPH). This is not necessarily torrential bleeding, and is usually defined as bleeding from the genital tract of $500 \mathrm{ml}$ or more in the first 24 hours following delivery of the baby. Alternative cut-off points of $600 \mathrm{ml}$ (Beischer 1986) and $1000 \mathrm{ml}$ (Burchell 1980) have also been suggested, and it has long been recognised that such clinical estimation is likely to underestimate the actual volume of blood lost by 34\% to 50\% (Newton 1961). This may in part explain the variation in estimated incidence of $\mathrm{PPH}$ between 5\% and 18\% (Hall 1985; Gilbert 1987; Prendiville 1988a), even within a single country like the UK, where PPH remains an important cause of maternal mortality (DoH 2004; Hall 1985; Gilbert 1987). Effects on maternal morbidity are less well documented, but are likely to include such inter-related outcomes as anaemia, fatigue and depression.

Nearly all maternal deaths (99\%) occur in the developing world (Kwast 1991), where other factors, such as infection (especially

Prophylactic oxytocin for the third stage of labour (Review)

Copyright $\odot 2010$ The Cochrane Collaboration. Published by John Wiley \& Sons, Ltd. 
HIV infection), poor nutritional status and lack of easy access to treatment, may contribute to death in the presence of severe postpartum haemorrhage. Many more women survive and suffer serious illness as a result, not only from the effects of acute anaemia but also from the interventions which a severe haemorrhage may necessitate (such as general anaesthesia, manual removal of the placenta, blood transfusion, hysterectomy). Other aspects of the management of labour such as induction and augmentation of labour, or the duration of the second stage in the context of epidural anaesthesia may also have relevance for the third stage. Reducing the likelihood of postpartum haemorrhage by avoiding the use of birth chairs in the second stage (Crowley 1991) could play a part in reducing maternal morbidity and mortality.

This review concentrates on components of such management in the third stage of labour. One component may be uterotonic drugs which increase the tone of the uterine muscles. These uterotonics were initially introduced for the treatment of PPH. Moir (Moir 1932) showed that ergometrine was the active principle on which the known uterotonic effect of ergot had depended. Reviewing its use in obstetric practice by the early 1950s, his opinion was that "Few drugs can have become so firmly established in so short a time and few drugs can be so completely indispensable as ergometrine is now" (Moir 1955). Ergometrine (ergonovine in the United States) became popular for routine management in the early 1950s. Oxytocin is a naturally occurring uterotonic, which Du Vigneaud et al synthesised and reported in 1953 (Du Vigneaud 1953). Embrey et al (Embrey 1963) reported advantages of combining this with ergometrine (as Syntometrine - oxytocin five international units plus ergometrine $0.5 \mathrm{mg}$ ). In order to prevent blood loss, these uterotonics and, more recently, prostaglandins are also being used for prophylactic third stage management.

While few would dispute the contribution of uterotonic drugs in the treatment of $\mathrm{PPH}$, their role in routine prophylaxis is less clear. This review considers the prophylactic role of one of these uterotonics, oxytocin, in the third stage of labour. Other relevant published reviews are by Prendiville 2000, which compare active with expectant third stage management (where active management involves the package of interconnected interventions of prophylactic uterotonics, early cutting and clamping of the umbilical cord, and controlled cord traction); Gülmezoglu 2004 and McDonald 2004, which both consider the role of different prophylactic uterotonics (prostaglandins, and ergometrine-oxytocin compared to oxytocin, respectively) in third stage management; and Carroli 2001 looking at the role of umbilical vein injection for the treatment of retained placenta. Subsequent third stage management reviews will consider the role of prophylactic uterotonics more generally, and of prophylactic ergot alkaloids particularly. As these interventions are very inter-related, some aspects of the role of oxytocin may be found in these other reviews (e.g. Prendiville 2000; Gülmezoglu 2004; McDonald 2004).

\section{O B J E C T I V E S}

The objective of this review is to examine the effect of oxytocin given prophylactically in the third stage of labour, defined as that period from birth of the baby until delivery of the placenta, on outcomes such as maternal blood loss and the length of the third stage of labour, other effects on the mother, and the outcome for the newborn baby. The objectives of this review will consider the following comparisons:

1. oxytocin versus no uterotonics;

2. oxytocin versus ergot alkaloids;

3. oxytocin plus ergometrine versus ergot alkaloids.

\section{METHODS}

\section{Criteria for considering studies for this review}

\section{Types of studies}

All acceptably randomised or quasi-randomised controlled trials were considered for inclusion, with exclusions on quality grounds if there was potential for significant selection bias after trial entry.

\section{Types of participants}

All trials including pregnant women anticipating a vaginal delivery were considered, regardless of other aspects of third stage management.

\section{Types of interventions}

Oxytocin given prophylactically for the third stage of labour, at whatever dose. The current review concentrates on oxytocin given by injection, usually into a maternal vein or a muscle. The role of prophylactic prostaglandins or ergot alkaloids, and uterotonics given through the umbilical vein, or for the treatment of blood loss or retained placenta, will be the subject of other reviews and are not included here. Similarly, endogenous oxytocin (nipple stimulation) is not included in this review.

\section{Types of outcome measures}

- Postpartum haemorrhage (PPH) (reported estimates of blood loss greater than or equal to $500 \mathrm{ml}$ )

- Severe PPH (clinically estimated blood loss greater than or equal to $1000 \mathrm{ml}$ )

- Mean blood loss (ml)

- Maternal haemoglobin concentration $(\mathrm{Hb})$ less than $9 \mathrm{gm} /$ decilitre 24 to 48 hours postpartum 
- Blood transfusion

- Iron tablets during the puerperium

- Therapeutic uterotonics

- Third stage greater than 20 minutes

- Third stage greater than 40 minutes

- Mean length of third stage (minutes)

- Manual removal of the placenta

- Subsequent surgical evacuation of retained products of conception

- Diastolic blood pressure greater than $100 \mathrm{mmHg}$ between delivery of baby and discharge from the labour ward

- Vomiting between delivery of baby and discharge from the labour ward

- Nausea between delivery of baby and discharge from the labour ward

- Headache between delivery of baby and discharge from the labour ward

- Maternal pain during third stage of labour

- Maternal dissatisfaction with third stage management

- Secondary PPH (after 24 hours and before six weeks)

- Bleeding needing readmission or antibiotics

- Maternal fatigue at six weeks

- Apgar score less than seven at five minutes

- Admission to special care baby unit

- Jaundice (as defined by the authors)

- Not breastfeeding at discharge from hospital

- Not breastfeeding at six weeks

\section{Search methods for identification of studies}

\section{Electronic searches}

We searched the Cochrane Pregnancy and Childbirth Group Trials Register by contacting the Trials Search Co-ordinator (December 2004). We updated this search on 1 October 2009 and added the results to Studies awaiting classification.

The Cochrane Pregnancy and Childbirth Group's Trials Register is maintained by the Trials Search Co-ordinator and contains trials identified from:

1. quarterly searches of the Cochrane Central Register of Controlled Trials (CENTRAL);

2. weekly searches of MEDLINE;

3. handsearches of 30 journals and the proceedings of major conferences;

4. weekly current awareness alerts for a further 44 journals plus monthly BioMed Central email alerts.

Details of the search strategies for CENTRAL and MEDLINE, the list of handsearched journals and conference proceedings, and the list of journals reviewed via the current awareness service can be found in the 'Specialized Register' section within the edito- rial information about the Cochrane Pregnancy and Childbirth Group.

Trials identified through the searching activities described above are each assigned to a review topic (or topics). The Trials Search Co-ordinator searches the register for each review using the topic list rather than keywords.

\section{Data collection and analysis}

For the first publication, two review authors checked the titles and abstracts identified from the search. Two of the review authors obtained the full text of all studies of possible relevance for independent assessment. The methodological quality of the studies was assessed with particular concentration on allocation concealment, ranked using the Cochrane approach of adequate, uncertain or inadequate. Two review authors performed the data extraction. Trial authors were contacted for clarification where relevant. Analysis was by intention to treat.

For this update the following methods were used.

\section{Selection of studies}

We assessed for inclusion all potential studies we identified as a result of the search strategy. We resolved any disagreement through discussion.

\section{Assessment of methodological quality of included studies}

We assessed the validity of each study using the criteria outlined in the Cochrane Reviewers' Handbook (Alderson 2004).

\section{(I) Selection bias (randomisation and allocation concealment)}

We planned to assign a quality score for each trial, using the following criteria:

(A) adequate concealment of allocation, such as telephone randomisation, consecutively numbered sealed opaque envelopes;

(B) unclear whether adequate concealment of allocation; such as list or table used, sealed envelopes, or study does not report any concealment approach;

(C) inadequate concealment of allocation, such as open list of random number tables, use of case record numbers, dates of birth or days of the week.

\section{(2) Performance bias (blinding of participants, researchers} and outcome assessment)

We planned to assess blinding using the following criteria:

(A) blinding of participants (yes/no/unclear);

(B) blinding of caregiver (yes/no/unclear); 
(C) blinding of outcome assessment (yes/no/unclear).

(3) Attrition bias (loss of participants, e.g. withdrawals, dropouts, protocol deviations)

We planned to assess completeness to follow up using the following criteria:

(A) less than $5 \%$ loss of participants;

(B) $5 \%$ to $10 \%$ loss of participants;

(C) more than $10 \%$ and less than $20 \%$ loss of participants;

(D) more than $20 \%$ loss of participants.

\section{Data extraction and management}

We planned for all three review authors to extract the data and to resolve discrepancies through discussion. We planned to use the Review Manager software (RevMan 2003) to double-enter the data.

\section{Measures of treatment effect}

We planned to carry out statistical analysis using the Review Manager software (RevMan 2003) and would have used a fixed-effect meta-analysis for combining data if trials were sufficiently similar. For dichotomous data: we planned to present results as summary relative risk with $95 \%$ confidence intervals.

For continuous data: we planned to use the weighted mean difference if outcomes were measured in the same way between trials. We planned to use the standardised mean difference to combine trials that measured the same outcome, but used different methods. If there was evidence of skewness this would have been reported.

We planned to analyse data on an intention-to-treat basis. Therefore, all participants with available data would have been included in the analysis in the group to which they were allocated, regardless of whether or not they received the allocated intervention. If in the original reports participants were not analysed in the group to which they were randomised, and there was sufficient information in the trial report, we would have attempted to restore them to the correct group.

\section{Assessment of heterogeneity}

Tests of heterogeneity between trials would have been applied if appropriate using the $\mathrm{I}^{2}$ statistic. If we identified high levels of heterogeneity among the trials, (exceeding 50\%), we would have explored it by prespecified subgroup analysis and have performed sensitivity analysis. A random-effects meta-analysis would have been used as an overall summary if considered appropriate. Three comparisons would have been considered:

(a) oxytocin versus no uterotonics;

(b) oxytocin versus ergot alkaloids;

(c) oxytocin plus ergometrine versus ergot alkaloids.
Subgroup analyses were planned based on extent of control for selection bias, on whether the oxytocin is administered within the context of active or expectant management of the third stage of labour, and on the timing of administration. Further subgroup analyses may consider the effects of different doses or different routes of administration if appropriate data become available. Results are presented as relative risks for dichotomous data, and weighted mean difference for continuous data, both with $95 \%$ confidence intervals using a fixed-effect model. If sufficient heterogeneity existed, sensitivity analyses would have be performed.

\section{R E S U L T S}

\section{Description of studies}

See: Characteristics of included studies; Characteristics of excluded studies.

Forty-six trials were identified as being potentially eligible for this review. Twenty-nine of these trials were excluded because: oxytocin was being compared to ergometrine-oxytocin (Docherty 1982; Dumoulin 1981; Soriano 1995; Symes 1984; Yuen 1995); no clinical outcome data were available (Hacker 1979; Muller 1996; Vaughan Williams1974); very strong likelihood of selection bias (Friedman 1957; Nieminen 1963; Stearn 1963; Thornton 1988); comparison of oxytocin given by different routes or at different times (Francis (1) 1965b; Huh 2000; Khan 1997; Thornton 1988; Hoffman 2004; Jackson 2001; Porter 1991; Schaefer 2004) (see Characteristics of excluded studies). The remaining 14 trials conducted in hospital and/or developed country settings were included in this review (see Characteristics of included studies). (Ten reports from an updated search in October 2009 have been added to Studies awaiting classification.)

\section{Risk of bias in included studies}

\section{Comparison A: oxytocin versus no uterotonics}

Eight trials are potentially included in this comparison (De Groot 1996; Howard 1964; Ilancheran 1990; McGinty 1956; Newton 1961; Nordstrom 1997; Pierre 1992; Poeschmann 1991), but McGinty 1956 provides no usable data for this part of the review. Four of the remaining seven had adequate allocation concealment (De Groot 1996; Howard 1964; Nordstrom 1997; Poeschmann 1991). 


\section{Comparison B: oxytocin versus ergot alkaloids}

Six trials are included in this comparison (De Groot 1996; Fugo 1958; Howard 1964; Ilancheran 1990; McGinty 1956; Sorbe 1978). Three had adequate allocation concealment (De Groot 1996; Fugo 1958; Howard 1964).

\section{Comparison C: oxytocin plus ergometrine versus ergot alkaloids}

Five trials are included in this comparison (Barbaro 1961; Bonham 1963; Francis (2) 1965a; Ilancheran 1990; Soiva 1964). Two had adequate allocation concealment (Bonham 1963; Francis (2) 1965a).

\section{Effects of interventions}

Fourteen trials are included.

\section{Comparison A: oxytocin versus no uterotonics}

Over 3000 women were entered into the trials of this comparison. There was considerable variation even within these seven trials. For instance, the sample size ranged from 10 to 1000 women. The oxytocin was given intramuscularly in three trials (De Groot 1996; Newton 1961; Poeschmann 1991), and intravenously in four trials (Howard 1964; Ilancheran 1990; Nordstrom 1997; Pierre 1992). The dose also varied from three international units (IU) (Howard 1964) to 5 IU (De Groot 1996; Pierre 1992; Poeschmann 1991) to $10 \mathrm{IU}$ (Nordstrom 1997). In the trial by Ilancheran 1990, the only information given is that it was the 'standard dose'. The nonoxytocin group was either 'nothing' (Ilancheran 1990; Newton 1961; Pierre 1992) or a saline placebo (Howard 1964; Nordstrom 1997; Poeschmann 1991). In one trial (De Groot 1996), an oral placebo was given to allow blinding with a third group given oral ergometrine. In two trials, the oxytocin was given after placental delivery (Howard 1964; Newton 1961). In two trials, the study was carried out within the context of expectant management of the third stage of labour (De Groot 1996; Nordstrom 1997), and in one within active management (Pierre 1992). For the remainder, the context was unclear.

The data from these studies reveal some clear benefits to women who received prophylactic oxytocin as part of the routine management of the third stage of labour when compared to women who did not receive a uterotonic. These benefits relate specifically to indicators of blood loss such as postpartum haemorrhage (whether greater than $500 \mathrm{ml}$ (relative risk (RR) 0.50 ; 95\% confidence interval (CI) 0.43 to 0.59 ) or greater than $1000 \mathrm{ml}$ (RR $0.61 ; 95 \%$ CI 0.44 to 0.87 ) and the need for therapeutic oxytocics (RR 0.50 ; $95 \%$ CI 0.39 to 0.64 ). This conclusion holds regardless of the prespecified stratifying factors detailed in the Methods section above, although with wider confidence intervals as the numbers of trials and therefore women is reduced. It is not feasible to comment on a possible relationship with manual removal of the placenta or the need for a blood transfusion. For all other outcomes in the review, either there are no data or the number of adverse events is very small, and so definite conclusions cannot be drawn.

\section{Comparison B: oxytocin versus ergot alkaloids}

Over 2800 women were entered into the trials of this comparison. There was considerable variation even within these six trials. For instance, the sample size ranged from 10 to over 1000 women. The oxytocin was given intramuscularly in only one trial (De Groot 1996), intravenously in four trials (Fugo 1958; Howard 1964; Ilancheran 1990; Sorbe 1978) and both intramuscularly and intravenously in one trial (McGinty 1956). The dose also varied from 2 IU (Fugo 1958), to 3 IU (Howard 1964) to 5 IU (De Groot 1996) to 10 IU (McGinty 1956; Sorbe 1978). In the trial by Ilancheran 1990, the only information given is that it was the 'standard dose'. The ergot alkaloid arm was even more varied, ranging from slightly different preparations - ergometrine/ergonovine (De Groot 1996; Fugo 1958; Ilancheran 1990; McGinty 1956; Sorbe 1978), methylergonovine maleate (Howard 1964), and methergine (McGinty 1956); different doses - from $0.2 \mathrm{mg}$ (Howard 1964; McGinty 1956; Sorbe 1978), to $0.4 \mathrm{mg}$ (De Groot 1996), $4 \mathrm{mg}$ (Fugo 1958), and the 'standard dose' in Ilancheran 1990; and different routes - all intravenous except oral in De Groot 1996. In one trial, the oxytocin was given after placental delivery (Howard 1964), and in one trial, the study was carried out within the context of expectant management of the third stage of labour (De Groot 1996). For the remainder, the context was unclear.

Overall there is little evidence of differential effects of these two oxytocics. There are only two exceptions to this picture: oxytocin is associated with fewer manual removals of the placenta (RR 0.57; 95\% CI 0.41 to 0.79 ), and with the suggestion of less raised blood pressure (RR $0.53 ; 95 \%$ CI 0.19 to 1.52 ), than are ergot alkaloids. For all other outcomes in the review, either there are no data or the number of adverse events is very small, and so definite conclusions cannot be drawn.

\section{Comparison C: oxytocin plus ergometrine versus ergot alkaloids}

Over 2800 women were entered into the trials of this comparison. There was considerable variation even within these five trials. For instance, the sample size ranged from 10 to over 1000 women. The ergometrine-oxytocin was generally given intramuscularly, although in one trial it was given intravenously (Ilancheran 1990). The dose was standard-one ampoule containing oxytocin $5 \mathrm{IU}$ and ergometrine $0.5 \mathrm{mg}$. The ergot alkaloid arm was more varied, ranging from slightly different preparations - ergometrine (Bonham 1963; Francis (2) 1965a; Ilancheran 1990), ergometrine maleate (Barbaro 1961), and methergine (Soiva 1964); different doses - from $0.12 \mathrm{mg}$ (Soiva 1964), to $0.5 \mathrm{mg}$ (Bonham 1963; 
Francis (2) 1965a), $0.10 \mathrm{mg}$ (Barbaro 1961), and the 'standard dose' in Ilancheran 1990; and different routes - intravenous in Ilancheran 1990 and Soiva 1964, intramuscular in Bonham 1963 and Francis (2) 1965a, and both in Barbaro 1961. The oxytocics were given before placental delivery in all the trials. Whether the trial was carried out within the context of expectant or of active management was usually unclear (although one (Bonham 1963) was a factorial design in which the other factors were controlled cord traction or maternal effort).

Overall, there is little evidence of a synergistic effect of adding oxytocin to ergometrine alone, other than in terms of reducing the rate of blood loss greater than $500 \mathrm{ml}$ in the subgroup of wellrandomised trials (RR $0.44 ; 95 \%$ CI 0.20 to 0.94 ). For all other outcomes in the review, either there are no data or the number of adverse events is very small, and so definite conclusions cannot be drawn.

\section{DISCUSSION}

Overall, there are too few data available for many definite conclusions to be drawn about the role of prophylactic oxytocin in the third stage of labour. There are strong suggestions of benefit in terms of postpartum haemorrhage, and the need for therapeutic oxytocics, when compared to using no uterotonic, but without sufficient information about other outcomes and side-effects, it is difficult to be confident about the trade-offs for these benefits. Indeed, there is a suggestion that the risk of manual removal of the placenta may be increased, particularly within the context of oxytocin without the other components of active management (early cord clamping/cutting and controlled cord traction). There seems little evidence in favour of ergot alkaloids alone compared to either oxytocin alone, or to ergometrine-oxytocin, but the data are sparse.

There were insufficient data to examine the role of different doses or routes of administration.

Suggested implications of the findings for practice and research are shown below.

\section{A U THORS, CONCLUSIONS}

\section{Implications for practice}

Before making major changes to practice based on the current review, further information from other reviews considering the role of active management (Prendiville 2000), of prostaglandins (Gülmezoglu 2004), and of ergot alkaloids (McDonald 2004) needs to be taken into account.
Nevertheless, given the benefit of oxytocin in terms of reducing postpartum haemorrhage and the need for therapeutic oxytocics, when compared to using no uterotonic, there appears to be a clear practice implication in favour of using oxytocin. This has to be tempered, however, by the knowledge that there is insufficient information about most other outcomes and side-effects, and that all the trials were conducted in hospitals and/or developed country settings.

Similarly, although the data are sparse, the balance of evidence does not support the prophylactic use of ergot alkaloids alone (in contrast to either oxytocin alone, or to ergometrine-oxytocin).

\section{Implications for research}

Domiciliary deliveries in developing countries shoulder the burden of most of the major adverse effects of complications arising from the management of the third stage of labour. In order to improve this situation, especially where the routine management is expectant, there is a need to conduct a trial to see whether active management would be preferable in these settings. Prior to this, there needs to be evidence about which form of active management might be most appropriate to consider. This implies the need for a trial of alternative uterotonics such as the current World Health Organization trial comparing oral misoprostol with oxytocin in the context of full active management, and a trial to see whether all the components of the full active management package are useful. The optimal dosing of oxytocin and route of administration need to be determined in addition to dispelling concerns of potential side-effects. Delivery systems for oxytocin need to be addressed especially in developing countries such as oxytocin delivery in the prefilled Uniject injection device. These trials should address outcomes which are of immediate relevance to the majority of postpartum women such as fatigue, and the ability to care for their babies.

[Note: The ten citations in the awaiting classification section of the review may alter the conclusions of the review once assessed.]

\section{ACKNOWLEDGEMENTS}

Clinical and consumer referees, and the staff at the editorial office. Thanks to the original review authors Prof Walter Prendiville, Diana Elbourne and Juliet Wood.

As part of the pre-publication editorial process, this updated review has been commented on by two peers (an editor and a referee who are external to the editorial team) and the Group's Statistical Adviser.

Prophylactic oxytocin for the third stage of labour (Review) 


\section{R E F E R E N C E S}

\section{References to studies included in this review}

Barbaro 1961 \{published data only\}

Barbaro CA, Smith GO. Clinical trial of SE505 - a new oxytocic mixture. Australian and New Zealand Journal of Obstetrics and Gynaecology 1961;1:147-50.

Bonham 1963 \{published data only\}

Bonham DG. Intramuscular oxytocics and cord traction in third stage of labour. BMJ 1963;2:1620-3.

De Groot 1996 \{published data only\} De Groot ANJA, Van Roosmalen J, Van Dongen PWJ, Borm GF. A placebo-controlled trial of oral ergometrine to reduce postpartum hemorrhage. Acta Obstetricia et Gynecologica Scandinavica 1996;75:464-8.

Francis (2) 1965a \{published data only\} Francis HH, Miller JM, Porteous CR. Clinical trial of an oxytocin-ergometrine mixture. Journal of Obstetrics and Gynaecology 1965;5:47-51.

Fugo 1958 \{published data only\}

Fugo NW, Dieckmann WJ. A comparison of oxytocic drugs in the management of the placental stage. American Journal of Obstetrics and Gynecology 1958;76:141-6.

Howard 1964 \{published data only\} Howard WF, McFadden PR, Keettel WC. Oxytocic drugs in fourth stage of labor. JAMA 1964;189:411-3.

Ilancheran 1990 \{published data only\} Ilancheran A, Ratnam SS. Effect of oxytocics on prostaglandin levels in the third stage of labour. Gynecologic and Obstetric Investigation 1990;29:177-80.

McGinty 1956 \{published data only\} McGinty LB. A study of the vasopressor effects of oxytocics when used intravenously in the third stage of labour. Western Journal of Surgery 1956;64:22-8.

Newton 1961 \{published data only\} Newton M, Mosey LM, Egli GE, Gifford WB, Hull CT. Blood loss during and immediately after delivery. Obstetrics \& Gynecology 1961;17:9-18.

Nordstrom 1997 \{published data only\}

Nordstrom L, Fogelstam K, Fridman G, Larsson A, Rydhstroem H. Routine oxytocin in the third stage of labour: a placebo controlled randomised trial. British Journal of Obstetrics and Gynaecology 1997;104:781-6.

Pierre 1992 \{published data only\}

Pierre F, Mesnard L, Body G. For a systematic policy of iv oxytocin inducted placenta deliveries in a unit where a fairly active management of third stage of labour is yet applied: results of a controlled trial. European Journal of Obstetrics \& Gynecology and Reproductive Biology 1992;43:131-5.

Poeschmann 1991 \{published data only\} Poeschmann RP, Doesburg WH, Eskes TKAB. A randomized comparison of oxytocin, sulprostone and placebo in the management of the third stage of labour.
British Journal of Obstetrics and Gynaecology 1991;98:

528-30.

Soiva 1964 \{published data only\}

Soiva K, Koistinen O. Clinical experience with simultaneous intramuscular injection of oxytocin and methylergometrine. Annales Chirurgiae et Gynaecologiae 1964;53:173-86.

\section{Sorbe 1978 \{published data only\}}

Sorbe B. Active pharmacologic management of the third stage of labor. A comparison of oxytocin and ergometrine. Obstetrics \& Gynecology 1978;52:694-7.

\section{References to studies excluded from this review}

\section{Bader 2000 \{published data only\}}

Bader W, Ast S, Hatzmann W. The significance of acupuncture in the third stage of labour. Deutsche Zeitschrift fur Akupunktur 2000;43:264-8.

Bader W, Ast S, Reinehr J, Hackmann J, Hatzmann W. Oxytocin versus Akupunktur in der Plazentarperiode - eine prospektiv randomisierte Studie [abstract]. Geburtshilfe und Frauenheilkunde 2000;60 Suppl 1:S73.

Boucher 2004 \{published data only\} Boucher M, Nimrod C, Tawagi G. Carbetocin IM injection vs oxytocin IV infusion for prevention of postpartum hemorrhage in women at risk following vaginal delivery. American Journal of Obstetrics and Gynecology 2001;185(6 Pt 2):A494.

Boucher M, Nimrod CA, Tawagi GF, Meeker TA, Rennicks, White RE, et al.Comparison of carbetocin and oxytocin for the prevention of postpartum hemorrhage following vaginal delivery:a double-blind randomized trial. Journal of Obstetrics \& Gynaecology Canada: JOGC 2004;26(5): 481-8.

Docherty 1982 \{published data only\} Docherty PW, Hooper M. Choice of an oxytocic agent for routine use at delivery. Journal of Obstetrics and Gynaecology 1981;2:60.

Dumoulin 1981 \{published data only\} Dumoulin JG. A reappraisal of the use of ergometrine. Journal of Obstetrics and Gynaecology 1981;1:178-81.

Francis (1) 1965b \{published data only\} Francis HH, Miller JM, Porteous CR. Clinical trial of an oxytocin-ergometrine mixture. Journal of Obstetrics and Gynaecology 1965;5:47-51.

Friedman 1957 \{published data only\} Friedman EA. Comparative clinical evaluation of postpartum oxytocics. Journal of Obstetrics and Gynecology 1957;73:1306-13.

Gerstenfeld 2001 \{published data only\} Gerstenfeld T, Wing D. Rectal misoprostol versus intravenous oxytocin for the prevention of postpartum hemorrhage after vaginal delivery. American Journal of Obstetrics and Gynecology 2001;185:878-82. 
Hacker 1979 \{published data only\}

Hacker NF, Biggs JSG. Blood pressure changes when uterine stimulants are used after normal delivery. British Journal of Obstetrics Gynaecology 1979;86:633-6.

Hoffman 2004 \{published data only\} Hoffman M, Naqvi F, Sciscione A. A randomized trial of active versus expectant management of the third stage of labor. American Journal of Obstetrics and Gynecology 2004; 191(6 Suppl 1):S82.

Huh 2000 \{published data only\} Huh W, Chelmow D, Malone FD. A randomized, double-blinded, placebo controlled trial of oxytocin at the beginning versus the end of the third stage of labor for prevention of postpartum hemorrhage. American Journal of Obstetrics and Gynecology 2000;182(1 Pt 2):S130.

Irons 1994 \{published data only\}

Irons DW, Sriskandabalan P, Bullough CHW. A simple alternative to parenteral oxytocics for the third stage of labor. International Journal of Gynecology \& Obstetrics 1994; 46:15-8.

Jackson 2001 \{published data only\}

Jackson KJ, Allbert J, Schemmer G, Elliot M, Humphrey A, Taylor J. A randomized controlled trial comparing oxytocin administration before and after placental delivery in the prevention of postpartum hemorrhage. American Journal of Obstetrics and Gynecology 2001;185:873-7.

Khan 1997 \{published data only\}

Khan GQ, John IS, Chan T, Wani S, Doherty T. Controlled cord traction versus minimal intervention techniques in delivery of the placenta: a randomized controlled trial. American Journal of Obstetrics and Gynecology 1997;177(4): $770-4$.

Kundodyiwa 2001 \{published data only\} Kundodyiwa T, Majoko F, Rusakaniko S. Misoprostol versus oxytocin in the third stage of labor. International Journal of Gynecology \& Obstetrics 2001;75:235-41.

Lokugamage 2001 \{published data only\} Lokugamage A, Paine M, Bassaw-Balroop K, Sullivan K, El-Refaey H, Rodeck C. Active management of the third stage at caesarean section: a randomised controlled trial of misoprostol versus syntocinon. Australian and New Zealand Journal of Obstetrics \& Gynaecology 2001;41(4):411-4. Lokugamage AU, Paine M, Bassau-Balroop H, El-Refaey K, Sullivan K, Rodek C. Active management of the third stage at caesarean section: misoprostol vs syntocinon. XVI FIGO World Congress of Obstetrics \& Gynecology. 2000 Sept 3-8; Washington DC, USA 2000; Book 2:54.

Muller 1996 \{published data only\}

Muller R, Beck G. Active management of the third stage of labour. 19th Swiss Congress of the Swiss Society of Gynecology and Obstetrics; 1996 June; Interlaken, Switzerland. 1996.

Nieminen 1963 \{published data only\}

Nieminen U, Jarvinen PA. A comparative study of different medical treatments of the third stage of labour. Annales Chirurgiae et Gynaecologiae Fenniae 1963;53:424-9.
Parsons 2004 \{published data only\}

Parsons S, Ntumy YM, Walley RL, Wilson JB, Crane JMG, Matthews K, et al.Rectal misoprostol vs intramuscular oxytocin in the routine management of the third stage of labour. 30th British Congress of Obstetrics and Gynaecology; 2004 July 7-9; Glasgow, UK 2004;18. 2004.

Porter 1991 \{published data only\}

Porter KB, O’Brien WF, Collins MK, Givens P, Knuppel R, Bruskivage $\mathrm{L}$. A randomized comparison of umbilical vein and intravenous oxytocin during the puerperium. Obstetrics \& Gynecology 1991;78:254-6.

Ramirez 2001 \{published data only\}

Ramirez O, Benito V, Jimenez R, Valido C, Hernandez C, Garcia J. Third stage of labour: active or expectant management? preliminary results. Journal of Perinatal Medicine 2001;Suppl 1(Pt 2):364.

Schaefer 2004 \{published data only\}

Schaefer A, Klein L, Wolfe P, Heindricks G, Downs L, Guinn D. Double blind rct of early versus traditional oxytocin management in the third stage to prevent blood loss. American Journal of Obstetrics and Gynecology 2004; 191(6 Suppl 1):S69.

Schemmer 2001 \{published data only\} Schemmer G. A randomized controlled trial comparing prophylactic administration of oxytocin before and after placental delivery in the prevention of postpartum hemorrhage [abstract]. American Journal of Obstetrics and Gynecology 2001;184(1):S20.

Soriano 1995 \{published data only\} Soriano D, Dulitzki M, Schiff E, Barkai G, Seldman DS. A randomized prospective trial of oxytocin plus ergometrin vs oxytocin alone for prevention of postpartum hemorrhage. American Journal of Obstetrics and Gynecology 1995;172: 361.

Stearn 1963 \{published data only\}

Stearn RH. Syntometrine in the management of the third stage of labour. Journal of Obstetrics and Gynaecology of the British Commonwealth 1963;70:593-6.

Symes 1984 \{published data only\}

Symes JB. A study on the effect of ergometrine on serum prolactin levels following delivery. Journal of Obstetrics and Gynaecology 1984;5:36-8. [: Record 2022]

Tessier 2000 \{published data only\} Tessier JL, Davies GAL, Woodman MC, Lipson A. Maternal hemodynamics after oxytocin bolus versus infusion in the third stage of labor. American Journal of Obstetrics and Gynecology 2000;182(1 Pt 2):S128.

Thornton 1988 \{published data only\} Thornton S, Davison JM, Baylis PH. Plasma oxytocin during third stage of labour: comparison of natural and active management. BMJ 1988;297:167-9.

Vaughan Williams1974 \{published data only\} Vaughan Williams CA, Johnson A, Ledward R. A comparison of central venous pressure changes in the third stage of labour following oxytocic drugs and 
diazepam. Journal of Obstetrics and Gynaecology of the British Commonwealth 1974;81:596-9.

\section{Yuen 1995 \{published data only\}}

Yuen PM, Chan NST, Yim SF, Chang AMZ. A randomised double blind comparison of Syntometrine and Syntocinon in the management of the third stage of labour. British Journal of Obstetrics and Gynaecology 1995;102:377-80.

\section{References to studies awaiting assessment}

\section{Dickinson 2009 \{published data only\}}

Dickinson JE, Doherty DA. Optimization of third-stage management after second-trimester medical pregnancy termination. American Journal of Obstetrics \& Gynecology 2009;201(3):303.e1-7.

Dommisse 1980 \{published data only\}

Dommisse J. The routine use of oxytocic drugs in the third stage of labour [letter]. South African Medical Journal 1980; 46:549.

Hoffman 2006 \{published data only\} Hoffman M, Castagnola D, Naqvi F. A randomized trial of active versus expectant management of the third stage of labor [abstract]. American Journal of Obstetrics and Gynecology 2006;195(6 Suppl 1):S107.

Jago 2007 \{published data only\} Jago AA, Ezechi OC, Achinge GI, Okunlola MA. Effect of oxytocics on the blood pressure of normotensive Nigerian parturients. Journal of Maternal-Fetal \& Neonatal Medicine 2007;20(9):703-5.

Jerbi 2007 \{published data only\}

Jerbi M, Hidar S, Elmoueddeb, Chaieb A, Khairi H. Oxytocin in the third stage of labor. International Journal of Gynecology \& Obstetrics 2007;96(3):198-9.

Moodie 1976 \{published data only\} Moodie JE, Moir DD. Ergometrine, oxytocin and extradural analgesia. British Journal of Anaesthesia 1976;48:571-4.

Orji 2008 \{published data only\}

Orji E, Agwu F, Loto O, Olaleye O. A randomized comparative study of prophylactic oxytocin versus ergometrine in the third stage of labor. International Journal of Gynecology \& Obstetrics 2008;101(2):129-32.

Saito 2007 \{published data only\}

Saito K, Haruki A, Ishikawa H, Takahashi T, Nagase $\mathrm{H}$, Koyama M, et al.Prospective study of intramuscular ergometrine compared with intramuscular oxytocin for prevention of postpartum hemorrhage. Journal of Obstetrics and Gynaecology Research 2007;33(3):254-8.

Sariganont 1999 \{published data only\}

Sariganont J. Comparative study between syntocinon and methergin in prevention of postpartum hemorrhage. Thai Journal of Obstetrics and Gynaecology 1999;11(4):248.

Vasegh 2005 \{published data only\}

Vasegh FR, Bahiraie A, Mahmoudi M, Salehi L. Comparison of active and physiologic management of third stage of labor. HAYAT: The Journal of Tehran Faculty of Nursing \& Midwifery 2005;10(23):102.

\section{Additional references}

\section{Alderson 2004}

Alderson P, Green S, Higgins JPT, editors. Cochrane Reviewers' Handbook 4.2.2 [updated March 2004]. In: The Cochrane Library, Issue 1, 2004. Chichester, UK: John Wiley \& Sons, Ltd.

\section{Beischer 1986}

Beischer NA, Mackay EV. Obstetrics and the newborn. Eastbourne: Bailliere Tindall, 1986.

\section{Burchell 1980}

Burchell RC. Postpartum haemorrhage. In: Quilligan ES editor(s). Current therapy in obstetrics and gynaecology. Philadelphia: WB Saunders, 1980.

\section{Carroli 2001}

Carroli G, Bergel E. Umbilical vein injection for management of retained placenta. Cochrane Database of Systematic Reviews 2001, Issue 4.

\section{Crowley 1991}

Crowley P, Elbourne D, Ashurst H, Garcia J, Murphy $\mathrm{D}$, Guignan N. Delivery in an obstetric birth chair: a randomized controlled trial. British Journal of Obstetrics and Gynaecology 1991;98(7):667-74.

\section{DoH 2004}

Department of Health. Report on Confidential Enquiries into maternal deaths in the United Kingdom 2000-2. London: HMSO, 2004.

\section{Du Vigneaud 1953}

Du Vigneaud V, Ressler C, Tippet S. The sequence of amino acids in oxytocin with a proposal for the structure of oxytocin. Journal of Biological Chemistry 1953;205:949.

Embrey 1963

Embrey MP, Barber DTC, Scudamore JH. Use of syntometrine in prevention of post partum haemorrhage. BMJ 1963;1:1387-9.

\section{Gilbert 1987}

Gilbert L, Porter W, Brown V. Postpartum haemorrhage - a continuing problem. British Journal of Obstetrics and Gynaecology 1987;94:67-71.

\section{Gülmezoglu 2004}

Gülmezoglu AM, Forna F, Villar J, Hofmeyr GJ.

Prostaglandins for the prevention of postpartum haemorrhage. Cochrane Database of Systematic Reviews 2004, Issue 1. [MEDLINE: CD000494]

\section{Hall 1985}

Hall M, Halliwell R, Carr-Hill R. Concomitant and repeated happenings of complications of the third stage of labour. British Journal of Obstetrics and Gynaecology 1985; 92:732-8.

\section{Kwast 1991}

Kwast B. Postpartum haemorrhage: its contribution to maternal mortality. Midwifery 1991;7:64-7. 


\section{McDonald 2004}

McDonald S, Abbott JM, Higgins SP. Prophylactic ergometrine-oxytocin versus oxytocin for the third stage of labour. Cochrane Database of Systematic Reviews 2004, Issue 1. [MEDLINE: CD000201]

\section{Moir 1932}

Moir JC. The action of ergot preparation on the puerperal uterus. BMJ 1932;1:1119-22.

\section{Moir 1955}

Moir JC. The history of present day use of ergot. Canadian Medical Association Journal 1955;72:727-34.

\section{Prendiville 1988a}

Prendiville WJ, Harding JE, Elbourne DR, Stirrat GM. The Bristol third stage trial: active vs physiological management of third stage of labour. BMJ 1988;297:1295-300.

\section{Prendiville 2000}

Prendiville WJ, Elbourne D, McDonald S. Active versus expectant management of the third stage of labour. Cochrane Database of Systematic Reviews 2000, Issue 3.

\section{RevMan 2003}

The Cochrane Collaboration. Review Manager (RevMan). 4.2 for Windows. Oxford, England: The Cochrane Collaboration, 2003.

\section{UNICEF 1996}

Adamson P. A failure of imagination. Progress of Nations. UNICEF, 1996:2-9.

\section{WHO 1990}

WHO Report of technical working group. The prevention and management of postpartum haemorrhage. Geneva: World Health Organization, 1990 (WHO/MCH/90).

\section{References to other published versions of this review}

\section{Elbourne 1988}

Elbourne D, Prendiville W, Chalmers I. Choice of oxytocic preparation for routine use in the management of the third stage of labour: an overview of evidence from controlled trials. British Journal of Obstetrics and Gynaecology 1988;95: $17-30$.

\section{Elbourne 2001}

Elbourne DR, Prendiville WJ, Carroli G, Wood J, McDonald S. Prophylactic use of oxytocin in the third stage of labour. The Cochrane Database of Systematic Reviews 2001, Issue 4.

\section{Prendiville 1988b}

Prendiville W, Elbourne D, Chalmers I. The effect of routine oxytocic administration in the management of the third stage of labour: an overview of the evidence from controlled trials. British Journal of Obstetrics and Gynaecology 1988;95:3-16.

\section{Prendiville 1989}

Prendiville WJ, Elbourne DR. Care during the third stage of labour. In: Chalmers I, Enkin M, Keirse MJNC editor(s). Effective care in pregnancy and childbirth. Vol. 2, Oxford: Oxford University Press, 1989:1145-69.

* Indicates the major publication for the study 


\section{CHARACTERISTICS OF STUDIES}

\section{Characteristics of included studies [ordered by study ID]}

\section{Barbaro 1961}

\begin{tabular}{|c|c|c|}
\hline Methods & \multicolumn{2}{|c|}{$\begin{array}{l}\text { 'No selection was made'. } \\
\text { Timing of randomisation not stated. } \\
\text { Not blinded. }\end{array}$} \\
\hline Participants & \multicolumn{2}{|c|}{$\begin{array}{l}\text { Women admitted for delivery in one of } 2 \text { obstetric units in hospital in Melbourne, Australia. Over } 28 \\
\text { weeks }\end{array}$} \\
\hline Interventions & \multicolumn{2}{|c|}{$\begin{array}{l}\text { (1) Intramuscular SE } 505 \text { (synthetic preparation-mixture of } 5 \text { units of syntocin and } 0.5 \mathrm{mg} \text { ergometrine } \\
\text { maleate in } 1 \mathrm{ml} \text { ) given immediately after delivery of the baby }(\mathrm{n}=300) \text {. } \\
\text { (2) Intravenous } 0.5 \mathrm{mg} \text { ergometrine maleate given immediately after delivery of the baby + intramuscular } \\
0.5 \mathrm{mg} \text { ergometrine maleate after delivery of placenta }(\mathrm{n}=300) \text {. } \\
\text { Otherwise expectant } 3 \text { rd stage management (?). }\end{array}$} \\
\hline Outcomes & \multicolumn{2}{|c|}{$\begin{array}{l}\text { Postpartum haemorrhage (> } 600 \mathrm{ml} \text { ); average blood loss } 266 \text { vs } 219 \mathrm{ml} \text { (SD not given); average duration } \\
\text { of 3rd stage } 16 \text { vs } 13 \text { minutes (SD not given) }\end{array}$} \\
\hline \multicolumn{3}{|l|}{ Notes } \\
\hline \multicolumn{3}{|l|}{ Risk of bias } \\
\hline Item & Authors' judgement & Description \\
\hline Allocation concealment? & No & $\mathrm{C}$ - Inadequate \\
\hline
\end{tabular}

Bonham 1963

Methods Selection of drug was made by random numbers. Timing of randomisation not stated.

Not blinded.

Participants All vaginal deliveries April 1961 to October 1962 in hospital in London, except: multiple pregnancies, previous PPH or manual removal, forceps and breech deliveries must be postrandomisation exclusions but does not state how many were randomised), parity 4 or more, induction or augmentation with syntocinon

Interventions (1) Intramuscular $0.5 \mathrm{mg}$ ergometrine +5 units synthetic oxytocin, given at crowning of the head ( $\mathrm{n}=$ 391).

(2) Intramuscular $0.5 \mathrm{mg}$ ergometrine, given at crowning of the head $(\mathrm{n}=416)$.

[Third group of ergometrine + hyaluronidase not considered for this review.]

Women were also selected in random two-week groups to either controlled cord traction ( $\mathrm{n}=199$ ergometrine + oxytocin vs 217 ergometrine alone) or maternal effort/fundal pressure (192 vs 199).

No information about timing of cord clamping/cutting.

Outcomes

Primary postpartum haemorrhage ( $>568 \mathrm{ml}$ estimated by adding to measured quantity a figure for loss on linen and swabs used for perineal repair); mean blood loss (154 vs $178 \mathrm{ml}$, SD not given); mean length 
of third stage (6.3 vs 6.2 mins, SD not given); prolonged third stage (> 30 minutes); manual removal of placenta

Notes

Risk of bias

\begin{tabular}{l|ll}
\hline Item & Authors' judgement & Description \\
\hline Allocation concealment? & Yes & A - Adequate \\
\hline
\end{tabular}

\section{De Groot 1996}

Methods Hospital pharmacy supplied numbered boxes of tablets and ampoules according to computer-generated randomisation list. Informed consent asked in early labour. Assigned before delivery of baby's head. Double-blind for oral ergometrine vs placebo and unblinded for ergometrine and/or placebo vs oxytocin. Randomisation 1:2:2, oxytocin to ergometrine to placebo. Multicentre

Participants

Two university hospitals, a midwifery school and independent midwives in and around Nijmegen, Netherlands. Women expecting to deliver in one of these settings, and who did not develop following exclusion criteria: refusal, cardiovascular disease/hypertension, multiple pregnancy, non-cephalic presentation, polyhydramnios, tocolysis 2 hours prior to delivery, anticoagulant therapy, stillbirth, antepartum haemorrhage, chemical induction or augmentation (oxytocin, prostaglandins), instrumental/operative delivery (some of these must have been postrandomisation exclusions), anaemia $\mathrm{Hb}<6.8 \mathrm{mmol} / \mathrm{L}$ (timing not stated), previous third stage complications.

Four of 371 women were assigned to the study erroneously ( 3 forceps, 1 augmentation) and were excluded postrandomisation. Otherwise eligible women wishing a natural childbirth refused to enter the trial (numbers not stated)

Interventions $\quad$ All three interventions given immediately after birth of baby:

(1) intramuscular 5 IU oxytocin;

(2) oral $0.4 \mathrm{mg}$ ergometrine;

(3) oral placebo.

Other third stage management expectant (although no information given about timing of cord clamping/ cutting). When mother feels contractions or there are signs of separation, maternal effort encouraged, adopting position to aid gravity. If necessary, flat hand on abdomen to act as brace to aid pushing. Reattempt if placenta does not deliver spontaneously. If haemorrhage, administer extra oxytocics and/or controlled cord traction

Outcomes

Mean blood loss (ml); PPH (>= $500 \mathrm{ml}$ ); severe PPH (>= $1000 \mathrm{ml}$ ) (blood loss measured gravimetrically (fresh perineal pad under perineum to absorb blood or fluid; gauzes and pads collected until one hour after delivery of placenta and weighed. $100 \mathrm{~g}$ increase in weight considered equivalent to $100 \mathrm{ml}$ blood); length of third stage (11 (range 4-90), 15 (2-90), 14 (3-55) in oxytocin, ergometrine and placebo groups respectively. No information about whether mean or median, and SD not given); blood pressure 15, 30, 45 and 60 minutes after delivery of placenta, in institutional deliveries only (oral ergometrine showed no significant elevation); use of further oxytocics; manual removal of placenta; transfusion

Notes

Prophylactic oxytocin for the third stage of labour (Review)

Copyright () 2010 The Cochrane Collaboration. Published by John Wiley \& Sons, Ltd. 


\section{De Groot 1996 (Continued)}

\section{Risk of bias}

\begin{tabular}{|c|c|c|}
\hline Item & Authors' judgement & Description \\
\hline Allocation concealment? & Yes & A - Adequate \\
\hline
\end{tabular}

Francis (2) 1965a

\begin{tabular}{|c|c|c|}
\hline Methods & \multicolumn{2}{|c|}{$\begin{array}{l}\text { 'Ampoules used in rotation and participants were unselected'. } \\
\text { Blinded. }\end{array}$} \\
\hline Participants & \multicolumn{2}{|c|}{$\begin{array}{l}\text { Two maternity hospitals in Liverpool, UK. } \\
\text { All women expected to deliver except those in whom an abnormal third stage was anticipated (previous } \\
\mathrm{PPH} \text {, instrumental or breech deliveries, twin pregnancies, antepartum haemorrhage, severe anaemia, } \\
\text { intravenous oxytocin for induction or augmentation) }\end{array}$} \\
\hline Interventions & \multicolumn{2}{|c|}{$\begin{array}{l}\text { (1) } 1 \mathrm{ml} \text { intramuscular ergometrine-oxytocin ( } 5 \mathrm{IU} \text { oxytocin }+0.5 \mathrm{mg} \text { per } 1 \mathrm{ml} \text { ergometrine) after delivery } \\
\text { of baby and cord divided, AND } 1 \mathrm{ml} \text { water after placental delivery }(\mathrm{n}=171) \text {. } \\
\text { (2) } 0.5 \mathrm{mg} \text { intramuscular ergometrine after delivery of baby and cord divided, AND } 1 \mathrm{ml} \text { water after } \\
\text { placental delivery }(\mathrm{n}=183) \text {. } \\
\text { (3) } 1 \mathrm{ml} \text { intramuscular water after delivery of baby and cord divided, AND } 0.5 \mathrm{mg} \text { intramuscular er- } \\
\text { gometrine after placental delivery }(\mathrm{n}=167) \text {. } \\
\text { No information about controlled cord traction or timing of cord clamping, so not clear whether in context } \\
\text { of active or expectant management. } \\
\text { Comparison in review is between groups } 1 \text { and } 2 \text {. }\end{array}$} \\
\hline Outcomes & \multicolumn{2}{|c|}{$\begin{array}{l}\text { Blood loss (average } 4.9,6.4,7.0 \text { in groups } 1,2 \text { and } 3 \text { respectively - not clear whether mean or median } \\
\text { and no SD given); for the review, loss of }>20 \mathrm{oz} \text { has been taken as PPH; retained placenta } \\
\text { ( }>20 \text { minutes). }\end{array}$} \\
\hline \multicolumn{3}{|l|}{ Notes } \\
\hline \multicolumn{3}{|l|}{ Risk of bias } \\
\hline Item & Authors' judgement & Description \\
\hline Allocation concealment? & Yes & A - Adequate \\
\hline
\end{tabular}

Fugo 1958

Methods Numbered identical drug packages administered in rotation. Number meaningless to obstetrician. Blinded.

Participants

Women delivering in a hospital in Chicago, USA.

No details given of inclusion/exclusion criteria, but description of study participants showed that half had labour over 8 hours, and $98 \%$ received some anaesthetic agent 
Fugo 1958 (Continued)

\begin{tabular}{ll}
\hline Interventions & All administered intravenously in $2 \mathrm{ml}$ with anterior shoulder. \\
& $\begin{array}{l}\text { (1) } 2 \mathrm{IU} \text { pitocin (natural oxytocin) } \mathrm{n}=168 . \\
\text { (2) } 2 \mathrm{IU} \text { syntocinon (synthetic oxytocin) } \mathrm{n}=156 . \\
\text { (3) } 4 \mathrm{mg} \text { ergonovine } 149 .\end{array}$ \\
& $\begin{array}{l}\text { (4) } 80 \mathrm{mg} \text { U3772 (alpha, alpha diphenyl gamma dimethylamino N-methyl valeramide-HCl) } \mathrm{n}=151 . \\
\text { No other information about management of third stage. } \\
\text { Comparison for review is groups } 1 \text { and } 2 \text { combined vs group 3. } \\
\text { No information about other aspects of third stage management }\end{array}$ \\
\hline Outcomes & $\begin{array}{l}\text { Method of placental delivery (high \% of manual removals for teaching purposes if haemorrhage or } \\
\text { undelivered within } 10 \text { minutes); length of third stage (not significantly different between groups but data } \\
\text { only given for those delivered spontaneously ie within } 10 \text { minutes); blood loss with placenta; (one hour } \\
\text { postpartum (?)average blood loss } 50.2 \text { vs } 40.8 \text { ml; no SDs given) }\end{array}$ \\
\hline Notes & $\begin{array}{l}\text { Risk of bias } \\
\text { Item }\end{array}$ \\
\hline Allocation concealment? & Yes \\
\hline
\end{tabular}

\section{Howard 1964}

Methods Participants randomly selected for one of the 3 study drugs. A double-blind technique was used. Vials identical in appearance. Contents not known until completion of the study

Participants Women delivering vaginally in hospital in Iowa, USA between August 1962 and July 1963

Interventions $\quad$ Following placental delivery, slow intravenous $1 \mathrm{cc}$ injection of

A. $0.9 \%$ sodium chloride $(\mathrm{n}=475)$.

B. $0.2 \mathrm{mg}$ methylergonovine maleate $(\mathrm{n}=505)$.

C. 3.0 IU oxytocin $(n=479)$.

Comparisons in this review between $\mathrm{C}$ and $\mathrm{A}$, and $\mathrm{C}$ and $\mathrm{B}$.

No information about other aspects of third stage management

Outcomes Blood pressure 1, 2, 5, 10 and 40 minutes after placental delivery and then hourly for 4 hours; blood loss as estimated by attending physician; further treatment for uterine atony

Notes

Risk of bias

\begin{tabular}{l|ll}
\hline Item & Authors' judgement & Description \\
\hline Allocation concealment? & Yes & A - Adequate \\
\hline
\end{tabular}

Prophylactic oxytocin for the third stage of labour (Review) 
Ilancheran 1990

\begin{tabular}{|c|c|c|}
\hline Methods & \multicolumn{2}{|c|}{ 'Consecutive participants divided equally into 4 subgroups, distribution being done on a random basis' } \\
\hline Participants & \multicolumn{2}{|c|}{$\begin{array}{l}\text { Women in spontaneous labour between } 38 \text { and } 42 \text { weeks' gestation with normal vertex deliveries in } \\
\text { hospital in Singapore. } 17 / 20 \text { were multigravid }\end{array}$} \\
\hline Interventions & \multicolumn{2}{|c|}{$\begin{array}{l}\text { A. No oxytocic in 3rd stage and three groups given intravenous uterotonic in 'standard' doses with the } \\
\text { delivery of the anterior shoulder. } \\
\text { B. Oxytocin. } \\
\text { C. Ergometrine-oxytocin. } \\
\text { D. Ergometrine. } \\
\text { Comparisons for this review are: B vs A; B vs D; C vs D. }\end{array}$} \\
\hline Outcomes & \multicolumn{2}{|c|}{$\begin{array}{l}\text { Prostaglandin levels 5, 15b and } 30 \text { minutes after delivery (significant rise in all four groups but no } \\
\text { differences between the groups); postpartum haemorrhage }\end{array}$} \\
\hline \multicolumn{3}{|l|}{ Notes } \\
\hline \multicolumn{3}{|l|}{ Risk of bias } \\
\hline Item & Authors' judgement & Description \\
\hline Allocation concealment? & Unclear & B - Unclear \\
\hline
\end{tabular}

McGinty 1956

Methods 'Cases picked at random'.

Unblinded.

\begin{tabular}{ll} 
Participants & All vaginally delivered under pudendal block and demorol/scopolamine, in hospital in United States of \\
& America \\
\hline Interventions & $\begin{array}{l}\text { Drug given at birth of anterior shoulder: } \\
\text { A. } 1 \text { cc normal saline intravenously }(\mathrm{n}=50) . \\
\text { B. } 0.2 \mathrm{mg} \text { methergine intravenously }(\mathrm{n}=50) . \\
\text { C. } 0.2 \mathrm{mg} \text { ergonovine intravenously }(\mathrm{n}=50) . \\
\text { D. pitocin } 5 \mathrm{IU} \text { each intravenously and intramuscularly }(\mathrm{n}=50) . \\
\text { Comparisons for this review: } \\
\text { D vs A; D vs B and C. } \\
\text { No information about other aspects of third stage management }\end{array}$ \\
\hline Outcomes & $\begin{array}{l}\text { Diastolic and systolic blood pressure } 5,15 \text { and } 60 \text { minutes after administration - although data not provided } \\
\text { for control group; estimated severe blood loss over } 1000 \text { ml mentioned for one women in methergine series } \\
\text { and one in control group (not included in data tables as unlikely to have been systematically recorded) }\end{array}$ \\
\hline Notes & \\
\hline
\end{tabular}

Risk of bias

Prophylactic oxytocin for the third stage of labour (Review) 
McGinty 1956 (Continued)

\begin{tabular}{|c|c|c|}
\hline Item & Authors' judgement & Description \\
\hline Allocation concealment? & Unclear & B - Unclear \\
\hline
\end{tabular}

Newton 1961

\begin{tabular}{|c|c|c|}
\hline Methods & \multicolumn{2}{|c|}{ Alternate allocation not blinded. } \\
\hline Participants & \multicolumn{2}{|c|}{ Hospital in USA. No antenatal complications, term, no likely complication of labour and delivery } \\
\hline Interventions & \multicolumn{2}{|c|}{$\begin{array}{l}\text { A. } 1 \mathrm{ml} \text { synthetic oxytocin intramuscularly after placental delivery }(\mathrm{n}=50) \text {. } \\
\text { B. Control }(\mathrm{n}=50) \text {. } \\
\text { No information about other aspects of third stage management }\end{array}$} \\
\hline Outcomes & \multicolumn{2}{|c|}{ Blood loss, blood pressure, need for therapeutic oxytocics. } \\
\hline Notes & & \\
\hline \multicolumn{3}{|l|}{ Risk of bias } \\
\hline Item & Authors' judgement & Description \\
\hline Allocation concealment? & Unclear & D - Not used \\
\hline
\end{tabular}

\section{Nordstrom 1997}

\begin{tabular}{l|l}
\hline Methods & $\begin{array}{l}\text { Double-blind randomised. } \\
2 \text { sets of ampoules prepared and numbered according to computer generated schedule. Contents unknown } \\
\text { to women or caregivers }\end{array}$ \\
\hline Participants & $\begin{array}{l}\text { Hospital in Sweden. } \\
\text { Singleton cephalic vaginal deliveries. }\end{array}$ \\
\hline Interventions & $\begin{array}{l}1 \text { ml intravenous after delivery of baby. Passive (expectant) management of the placenta. } \\
10 \text { IU oxytocin. } \\
\text { Saline. }\end{array}$ \\
\hline Outcomes & $\begin{array}{l}\text { Blood loss; additional oxytocin (data tables give methylergometrine; clarification about other oxytocics } \\
\text { sought from authors), Hb, blood transfusion; manual removal }\end{array}$ \\
\hline Notes & $\begin{array}{l}\text { Additional oxytocin (data tables give methylergometrine; clarification about other oxytocics sought from } \\
\text { authors) }\end{array}$ \\
\hline Risk of bias & Authors judgement \\
\hline Item & Description \\
\hline
\end{tabular}




\section{Nordstrom 1997 (Continued)}

\begin{tabular}{lll} 
Allocation concealment? Yes $\quad$ A - Adequate \\
\hline
\end{tabular}

\section{Pierre 1992}

\begin{tabular}{|c|c|c|}
\hline Methods & \multicolumn{2}{|c|}{$\begin{array}{l}\text { Leaflets marked from 1-1000 alternate allocation 'this made possible a control of selection bias at entry by } \\
\text { the authors as the order in the trial had the same chronology as the date and time of entry in the labour } \\
\text { ward' }\end{array}$} \\
\hline Participants & \multicolumn{2}{|c|}{ Women expecting to deliver vaginally in hospital in France. Only exclusions - breech, twins, APH, refusal } \\
\hline Interventions & \multicolumn{2}{|c|}{$\begin{array}{l}\text { Active management of third stage with }(n=488) \text { and without } 5 \text { IU IV oxytocin }(n=488) \text { with the anterior } \\
\text { shoulder }\end{array}$} \\
\hline Outcomes & \multicolumn{2}{|c|}{ Blood loss; length of third stage, MRP, maternal side-effects } \\
\hline \multicolumn{3}{|l|}{ Notes } \\
\hline \multicolumn{3}{|l|}{ Risk of bias } \\
\hline Item & Authors' judgement & Description \\
\hline Allocation concealment? & No & $\mathrm{C}$ - Inadequate \\
\hline
\end{tabular}

Poeschmann 1991

Methods Hospital pharmacy supplied numbered boxes. Allocation of boxes was by order of entry to the labour ward. A nurse not working in the labour room prepared the injection

Participants April $1986-88,2$ hospitals in Netherlands.

Uncomplicated singleton term pregnancies in spontaneous labour with spontaneous vaginal deliveries and Hobel score of less than 10

\begin{tabular}{l|l} 
Interventions & After birth of baby: \\
& $\begin{array}{l}\text { A. IM } 5 \text { IU oxytocin. } \\
\text { B. } 500 \text { micrograms sulprostone. } \\
\text { C. saline. } \\
\text { Comparison in this review is A vs C. } \\
\text { Not sure whether active or expectant as says 3rd stage managed } \\
\text { clamped within } 1 \text { minute of birth }\end{array}$ \\
\hline Outcomes & Blood loss; need for additional oxytocics; length of third stage \\
\hline Notes & \\
\hline
\end{tabular}

Risk of bias

\begin{tabular}{l|l}
\hline Item & Authors' judgement
\end{tabular}


Poeschmann 1991 (Continued)

\begin{tabular}{|c|c|c|}
\hline Allocation concealment? & Yes & A - Adequate \\
\hline \multicolumn{3}{|l|}{ Soiva 1964} \\
\hline Methods & \multicolumn{2}{|c|}{ Every third normal parturient. } \\
\hline Participants & \multicolumn{2}{|c|}{$\begin{array}{l}\text { Hospital, Finland. } \\
\text { Spontaneous, singleton, cephalic. }\end{array}$} \\
\hline Interventions & \multicolumn{2}{|c|}{$\begin{array}{l}\text { Immediately after birth of baby. } \\
\text { No efforts to expel placenta during first contraction of third stage. } \\
\text { IV methergine } 0.12-0.2 \mathrm{mg} \\
\text { IM ergometrine-oxytocin (IU oxytocin }+0.5 \text { ergometrine). } \\
\text { Not clear whether rest of third stage managed actively or expectantly }\end{array}$} \\
\hline Outcomes & \multicolumn{2}{|c|}{ Blood loss; duration of third stage, retained placenta, complications, MRP } \\
\hline \multicolumn{3}{|l|}{ Notes } \\
\hline \multicolumn{3}{|l|}{ Risk of bias } \\
\hline Item & Authors' judgement & Description \\
\hline Allocation concealment? & No & $\mathrm{C}$ - Inadequate \\
\hline
\end{tabular}

\section{Sorbe 1978}

\begin{tabular}{|c|c|}
\hline Methods & $\begin{array}{l}\text { Alternate - odd and even numbers of mothers' hospital records. } \\
\text { Not blinded. }\end{array}$ \\
\hline Participants & Hospital in Sweden. \\
\hline Interventions & $\begin{array}{l}\text { IV after delivery of anterior shoulder. } \\
0.2 \text { mg ergometrine. } \\
10 \text { IU oxytocin. } \\
\text { Not clear whether rest of third stage managed actively or expectantly } \\
\text { (historical (?) control group given no uterotonic not included in the comparison) }\end{array}$ \\
\hline Outcomes & Blood loss; MRP, placental separation time. \\
\hline \multicolumn{2}{|l|}{ Notes } \\
\hline \multicolumn{2}{|l|}{ Risk of bias } \\
\hline Item & Authors' judgement \\
\hline
\end{tabular}


Sorbe 1978 (Continued)

\begin{tabular}{l|l}
\hline Allocation concealment? & No \\
\hline
\end{tabular}

APH: antepartum haemorrhage

Hb: haemoglobin

IM: intramuscular

IU: international units

IV: intravenous

MRP: manual removal of placenta

PPH: postpartum haemorrhage

SD: standard deviation

vs: versus

Characteristics of excluded studies [ordered by study ID]

\begin{tabular}{|c|c|}
\hline Study & Reason for exclusion \\
\hline Bader 2000 & Comparison of oxytocin to acupuncture not the subject of this review \\
\hline Boucher 2004 & $\begin{array}{l}\text { Comparison of intramuscular carbetocin to a } 2 \text { hour intravenous oxytocin infusion administered after } \\
\text { delivery of the fetus and placenta }\end{array}$ \\
\hline Docherty 1982 & Comparison of oxytocin to acupuncture not the subject of this review \\
\hline Dumoulin 1981 & Oxytocin (different doses) versus ergometrine-oxytocin (subject of separate review) \\
\hline Francis (1) $1965 \mathrm{~b}$ & $\begin{array}{l}\text { Excluded because ergometrine-oxytocin given after end of } 2 \text { nd stage and ergometrine given after end of } \\
\text { third stage, so the comparison of the two drugs is inextricably confounded with the timing of administration }\end{array}$ \\
\hline Friedman 1957 & $\begin{array}{l}\text { Likely to be considerable bias after entry to study as } 27 \% \text { of the } 1221 \text { were 'deleted from the study' as } \\
\text { inadequate observations were obtained. No other reasons given, and no indication of whether these women } \\
\text { were missing in similar proportions from the five intervention groups }\end{array}$ \\
\hline Gerstenfeld 2001 & Comparison of oxytocin to misoprostol (subject of separate review) \\
\hline Hacker 1979 & $\begin{array}{l}\text { Excluded because no clinical outcome date available except for information on blood pressure which is } \\
\text { only given as mean changes from baseline }\end{array}$ \\
\hline Hoffman 2004 & $\begin{array}{l}\text { Comparison of oxytocin within the context of active versus expectant management (subject of seperate } \\
\text { review) }\end{array}$ \\
\hline Huh 2000 & Excluded as only different timing of administration. \\
\hline Irons 1994 & Comparison of nipple stimulation to ergometrine-oxytocin which is not a subject of this review \\
\hline
\end{tabular}

Prophylactic oxytocin for the third stage of labour (Review) 
(Continued)

\begin{tabular}{|c|c|}
\hline Jackson 2001 & $\begin{array}{l}\text { Comparison of oxytocin administered before and after placental delivery so the only difference is timing } \\
\text { of administration }\end{array}$ \\
\hline Khan 1997 & $\begin{array}{l}\text { Comparison of prophylactic oxytocin within context of active management vs oxytocin after placental } \\
\text { delivery within context of expectant management (subject of separate review by Prendiville et al: Active } \\
\text { versus expectant management of third stage of labour - see Prendiville 2000) }\end{array}$ \\
\hline Kundodyiwa 2001 & Comparison of oxytocin to misoprostol (subject of separate review) \\
\hline Lokugamage 2001 & Comparison of oxytocin to misoprostol (subject of separate review) and at caesarean section \\
\hline Muller 1996 & $\begin{array}{l}5 \text { IU IV oxytocin with crowning of head and Brandt-Andrews vs expectant. Abstract only, in French and } \\
\text { German. No clinical data available from authors }\end{array}$ \\
\hline Nieminen 1963 & No details of how allocated 'women divided into three groups' - methergine, OCM505, oxytocin \\
\hline Parsons 2004 & Comparison of oxytocin to misoprostol (subject of separate review) \\
\hline Porter 1991 & Only difference is different route of administration. \\
\hline Ramirez 2001 & Inadequate information available about randomization and available only as abstract \\
\hline Schaefer 2004 & Excluded as only difference is timing of administration. \\
\hline Schemmer 2001 & $\begin{array}{l}\text { Comparison of oxytocin administered before and after placental delivery so the only difference is timing } \\
\text { of administration }\end{array}$ \\
\hline Soriano 1995 & Compares oxytocin to oxytocin plus ergometrine (subject of separate review) \\
\hline Stearn 1963 & $\begin{array}{l}\text { Allocation was to two different consultants one of whom gave all patients ergometrine-oxytocin, and the } \\
\text { other to give 'normal' cases ergometrine with hyalase and abnormal given IV ergometrine }\end{array}$ \\
\hline Symes 1984 & $\begin{array}{l}\text { Compares oxytocin to oxytocin plus ergometrine. } \\
\text { No clinical outcomes (serum prolactin levels only). }\end{array}$ \\
\hline Tessier 2000 & Excluded as only different routes of administration. \\
\hline Thornton 1988 & $\begin{array}{l}\text { Strong likelihood of post-entry bias as alternate allocation used for } 65 \text {, but } 40 \text { were withdrawn } 40 \text { as did } \\
\text { not meet inclusion criteria, leaving } 10 \text { and } 15 \text { in trial comparing oxytocin vs no oxytocin within active } \\
\text { management. Primary outcome plasma oxytocin concentration }\end{array}$ \\
\hline Vaughan Williams1974 & Excluded because no clinical outcome data available. \\
\hline Yuen 1995 & Oxytocin versus ergometrine-oxytocin (subject of separate review) \\
\hline
\end{tabular}

IU: international unit

Prophylactic oxytocin for the third stage of labour (Review) 
IV: intravenous

vs: versus

Prophylactic oxytocin for the third stage of labour (Review)

Copyright $\odot 2010$ The Cochrane Collaboration. Published by John Wiley \& Sons, Ltd. 
DATA ANDANALYSES

Comparison 1. Oxytocin versus no uterotonics (all trials)

\begin{tabular}{|c|c|c|c|c|}
\hline Outcome or subgroup title & $\begin{array}{l}\text { No. of } \\
\text { studies }\end{array}$ & $\begin{array}{c}\text { No. of } \\
\text { participants }\end{array}$ & Statistical method & Effect size \\
\hline $\begin{array}{l}1 \mathrm{PPH} \text { (clinically estimated blood } \\
\text { loss }>\text { or }=500 \mathrm{ml} \text { ) }\end{array}$ & 6 & 3193 & Risk Ratio (M-H, Fixed, 95\% CI) & $0.50[0.43,0.59]$ \\
\hline $\begin{array}{l}2 \text { Severe PPH (clinically estimated } \\
\quad \text { blood loss }>\text { or }=1000 \mathrm{ml} \text { ) }\end{array}$ & 4 & 2243 & Risk Ratio (M-H, Fixed, 95\% CI) & $0.61[0.44,0.87]$ \\
\hline 3 Mean blood loss $(\mathrm{ml})$ & 4 & 1373 & Mean Difference (IV, Fixed, 95\% CI) & $\begin{array}{l}-101.93[-134.89,- \\
68.97]\end{array}$ \\
\hline $\begin{array}{l}4 \text { Maternal haemoglobin } \\
\text { concentration }(\mathrm{Hb})<9 \\
\text { gm/deciltre } 24 \text { to } 48 \text { hours } \\
\text { postpartum }\end{array}$ & 1 & 943 & Risk Ratio (M-H, Fixed, 95\% CI) & $0.63[0.36,1.09]$ \\
\hline 5 Blood transfusion & 2 & 1221 & Risk Ratio (M-H, Fixed, 95\% CI) & $1.30[0.50,3.39]$ \\
\hline 7 Therapeutic uterontonics & 5 & 2327 & Risk Ratio (M-H, Fixed, 95\% CI) & $0.50[0.39,0.64]$ \\
\hline $\begin{array}{l}10 \text { Mean length of third stage } \\
\text { (minutes) }\end{array}$ & 1 & 52 & Mean Difference (IV, Fixed, 95\% CI) & $-1.80[-5.55,1.95]$ \\
\hline 11 Manual removal of the placenta & 4 & 2243 & Risk Ratio (M-H, Fixed, 95\% CI) & $1.17[0.79,1.73]$ \\
\hline $\begin{array}{l}15 \text { Nausea between delivery of the } \\
\text { baby and discharge from the } \\
\text { labour ward }\end{array}$ & 1 & 52 & Risk Ratio (M-H, Fixed, 95\% CI) & $0.29[0.01,6.74]$ \\
\hline
\end{tabular}

\section{Comparison 2. Oxytocin versus no uterotonics (randomised trials only)}

\begin{tabular}{|c|c|c|c|c|}
\hline Outcome or subgroup title & $\begin{array}{l}\text { No. of } \\
\text { studies }\end{array}$ & $\begin{array}{c}\text { No. of } \\
\text { participants }\end{array}$ & Statistical method & Effect size \\
\hline $\begin{array}{l}1 \mathrm{PPH} \text { (clinically estimated blood } \\
\quad \text { loss }>\text { or }=500 \mathrm{ml} \text { ) }\end{array}$ & 4 & 2213 & Risk Ratio (M-H, Fixed, 95\% CI) & $0.61[0.51,0.72]$ \\
\hline $\begin{array}{l}2 \text { Severe PPH (clinically estimated } \\
\quad \text { blood loss }>\text { or }=1000 \mathrm{ml} \text { ) }\end{array}$ & 3 & 1273 & Risk Ratio (M-H, Fixed, 95\% CI) & $0.72[0.49,1.05]$ \\
\hline 3 Mean blood loss $(\mathrm{ml})$ & 3 & 1273 & Mean Difference (IV, Fixed, 95\% CI) & $\begin{array}{l}-109.12[-151.93,- \\
66.32]\end{array}$ \\
\hline $\begin{array}{l}4 \text { Maternal haemoglobin } \\
\text { concentration }(\mathrm{Hb})<9 \\
\text { gm/deciltre } 24 \text { to } 48 \text { hours } \\
\text { postpartum }\end{array}$ & 1 & 943 & Risk Ratio (M-H, Fixed, 95\% CI) & $0.63[0.36,1.09]$ \\
\hline 5 Blood transfusion & 2 & 1221 & Risk Ratio (M-H, Fixed, 95\% CI) & $1.30[0.50,3.39]$ \\
\hline 7 Therapeutic uterontonics & 4 & 2227 & Risk Ratio (M-H, Fixed, 95\% CI) & $0.53[0.41,0.69]$ \\
\hline $\begin{array}{l}10 \text { Mean length of third stage } \\
\text { (minutes) }\end{array}$ & 1 & 52 & Mean Difference (IV, Fixed, 95\% CI) & $-1.80[-5.55,1.95]$ \\
\hline 11 Manual removal of the placenta & 3 & 1273 & Risk Ratio (M-H, Fixed, 95\% CI) & $1.67[0.82,3.41]$ \\
\hline
\end{tabular}


15 Nausea between delivery of the

Comparison 3. Oxytocin versus no uterotonics (active management only)

\begin{tabular}{lcccc} 
Outcome or subgroup title & $\begin{array}{c}\text { No. of } \\
\text { studies }\end{array}$ & $\begin{array}{c}\text { No. of } \\
\text { participants }\end{array}$ & Statistical method & Effect size \\
\hline $\begin{array}{c}1 \text { PPH (clinically estimated blood } \\
\text { loss }>\text { or }=500 \mathrm{ml})\end{array}$ & 1 & 970 & Risk Ratio (M-H, Fixed, 95\% CI) & $0.29[0.21,0.41]$ \\
$\begin{array}{c}2 \begin{array}{l}\text { Severe PPH (clinically estimated } \\
\text { blood loss > or }=1000 \mathrm{ml})\end{array} \\
\begin{array}{c}11 \text { Manual removal of the placenta } \\
\hline\end{array}\end{array}$ & 1 & 970 & Risk Ratio (M-H, Fixed, 95\% CI) & $0.33[0.14,0.77]$ \\
\end{tabular}

\section{Comparison 4. Oxytocin versus no uterotonics (expectant management only)}

\begin{tabular}{|c|c|c|c|c|}
\hline Outcome or subgroup title & $\begin{array}{l}\text { No. of } \\
\text { studies }\end{array}$ & $\begin{array}{c}\text { No. of } \\
\text { participants }\end{array}$ & Statistical method & Effect size \\
\hline $\begin{array}{l}1 \mathrm{PPH} \text { (clinically estimated blood } \\
\quad \text { loss }>\text { or }=500 \mathrm{ml} \text { ) }\end{array}$ & 2 & 1221 & Risk Ratio (M-H, Fixed, 95\% CI) & $0.61[0.51,0.73]$ \\
\hline $\begin{array}{l}2 \text { Severe PPH (clinically estimated } \\
\quad \text { blood loss }>\text { or }=1000 \mathrm{ml} \text { ) }\end{array}$ & 2 & 1221 & Risk Ratio (M-H, Fixed, 95\% CI) & $0.73[0.49,1.07]$ \\
\hline 3 Mean blood loss $(\mathrm{ml})$ & 2 & 1221 & Mean Difference (IV, Fixed, 95\% CI) & $\begin{array}{l}-83.58[-118.01,- \\
49.14]\end{array}$ \\
\hline $\begin{array}{l}4 \text { Maternal haemoglobin } \\
\text { concentration }(\mathrm{Hb})<9 \\
\text { gm/deciltre } 24 \text { to } 48 \text { hours } \\
\text { postpartum }\end{array}$ & 1 & 943 & Risk Ratio (M-H, Fixed, 95\% CI) & $0.63[0.36,1.09]$ \\
\hline 5 Blood transfusion & 2 & 1221 & Risk Ratio (M-H, Fixed, 95\% CI) & $1.30[0.50,3.39]$ \\
\hline 7 Therapeutic uterontonics & 2 & 1221 & Risk Ratio (M-H, Fixed, 95\% CI) & $0.66[0.48,0.90]$ \\
\hline 11 Manual removal of the placenta & 2 & 1221 & Risk Ratio (M-H, Fixed, 95\% CI) & $1.67[0.82,3.41]$ \\
\hline
\end{tabular}

\section{Comparison 5. Oxytocin versus no uterotonics (given before placental delivery)}

\begin{tabular}{|c|c|c|c|c|}
\hline Outcome or subgroup title & $\begin{array}{l}\text { No. of } \\
\text { studies }\end{array}$ & $\begin{array}{c}\text { No. of } \\
\text { participants }\end{array}$ & Statistical method & Effect size \\
\hline $\begin{array}{l}1 \mathrm{PPH} \text { (clinically estimated blood } \\
\quad \text { loss }>\text { or }=500 \mathrm{ml} \text { ) }\end{array}$ & 5 & 2253 & Risk Ratio (M-H, Fixed, 95\% CI) & $0.50[0.42,0.58]$ \\
\hline $\begin{array}{l}2 \text { Severe PPH (clinically estimated } \\
\text { blood loss }>\text { or }=1000 \mathrm{ml} \text { ) }\end{array}$ & 4 & 2243 & Risk Ratio (M-H, Fixed, 95\% CI) & $0.61[0.44,0.87]$ \\
\hline
\end{tabular}

Copyright $\odot 2010$ The Cochrane Collaboration. Published by John Wiley \& Sons, Ltd. 


\begin{tabular}{|c|c|c|c|c|}
\hline 3 Mean blood loss (ml) & 3 & 1273 & Mean Difference (IV, Fixed, 95\% CI) & $\begin{array}{l}-109.12[-151.93,- \\
66.32]\end{array}$ \\
\hline $\begin{array}{l}4 \text { Maternal haemoglobin } \\
\text { concentration }(\mathrm{Hb})<9 \\
\text { gm/deciltre } 24 \text { to } 48 \text { hours } \\
\text { postpartum }\end{array}$ & 1 & 943 & Risk Ratio (M-H, Fixed, 95\% CI) & $0.63[0.36,1.09]$ \\
\hline 5 Blood transfusion & 2 & 1221 & Risk Ratio (M-H, Fixed, 95\% CI) & $1.30[0.50,3.39]$ \\
\hline 7 Therapeutic uterontonics & 3 & 1273 & Risk Ratio (M-H, Fixed, 95\% CI) & $0.64[0.47,0.87]$ \\
\hline $\begin{array}{l}10 \text { Mean length of third stage } \\
\text { (minutes) }\end{array}$ & 1 & 52 & Mean Difference (IV, Fixed, 95\% CI) & $-1.80[-5.55,1.95]$ \\
\hline 11 Manual removal of the placenta & 4 & 2243 & Risk Ratio (M-H, Fixed, 95\% CI) & $1.17[0.79,1.73]$ \\
\hline $\begin{array}{l}15 \text { Nausea between delivery of the } \\
\text { baby and discharge from the } \\
\text { labour ward }\end{array}$ & 1 & 52 & Risk Ratio (M-H, Fixed, 95\% CI) & $0.29[0.01,6.74]$ \\
\hline
\end{tabular}

Comparison 6. Oxytocin versus no uterotonics (given after placental delivery)

\begin{tabular}{lcccc} 
Outcome or subgroup title & $\begin{array}{c}\text { No. of } \\
\text { studies }\end{array}$ & $\begin{array}{c}\text { No. of } \\
\text { participants }\end{array}$ & Statistical method & Effect size \\
\hline $\begin{array}{l}1 \mathrm{PPH} \text { (clinically estimated blood } \\
\text { loss }>\text { or }=500 \mathrm{ml})\end{array}$ & 1 & 940 & Risk Ratio (M-H, Fixed, 95\% CI) & $0.6[0.32,1.12]$ \\
$\begin{array}{l}3 \text { Mean blood loss }(\mathrm{ml}) \\
\text { Therapeutic uterontonics }\end{array}$ & 1 & 100 & Mean Difference (IV, Fixed, 95\% CI) & $\begin{array}{l}12.0[-102.29,126 . \\
29]\end{array}$ \\
7 Pisk Ratio (M-H, Fixed, 95\% CI) & $0.32[0.20,0.50]$ \\
\hline
\end{tabular}

\section{Comparison 7. Oxytocin versus ergot alkaloids (all trials)}

\begin{tabular}{|c|c|c|c|c|}
\hline Outcome or subgroup title & $\begin{array}{l}\text { No. of } \\
\text { studies }\end{array}$ & $\begin{array}{c}\text { No. of } \\
\text { participants }\end{array}$ & Statistical method & Effect size \\
\hline $\begin{array}{l}1 \mathrm{PPH} \text { (clinically estimated blood } \\
\quad \text { loss }>\text { or }=500 \mathrm{ml} \text { ) }\end{array}$ & 5 & 2719 & Risk Ratio (M-H, Fixed, 95\% CI) & $0.90[0.70,1.16]$ \\
\hline $\begin{array}{l}2 \text { Severe PPH (clinically estimated } \\
\quad \text { blood loss }>\text { or }=1000 \mathrm{ml} \text { ) }\end{array}$ & 3 & 1746 & Risk Ratio (M-H, Fixed, 95\% CI) & $0.99[0.56,1.74]$ \\
\hline 3 Mean blood loss $(\mathrm{ml})$ & 2 & 1273 & Mean Difference (IV, Fixed, 95\% CI) & $\begin{array}{l}-29.12[-59.36,1 \\
12]\end{array}$ \\
\hline 5 Blood transfusion & 1 & 224 & Risk Ratio (M-H, Fixed, 95\% CI) & $3.74[0.34,40.64]$ \\
\hline 7 Therapeutic uterontonics & 2 & 1208 & Risk Ratio (M-H, Fixed, 95\% CI) & $1.02[0.67,1.55]$ \\
\hline 8 Third stage $>20$ minutes & 1 & 473 & Risk Ratio (M-H, Fixed, 95\% CI) & Not estimable \\
\hline 9 Third stage $>40$ minutes & 1 & 383 & Risk Ratio (M-H, Fixed, 95\% CI) & Not estimable \\
\hline $\begin{array}{l}10 \text { Mean length of third stage } \\
\text { (minutes) }\end{array}$ & 1 & 1049 & Mean Difference (IV, Fixed, 95\% CI) & $-0.80[-1.65,0.05]$ \\
\hline 11 Manual removal of the placenta & 3 & 1746 & Risk Ratio (M-H, Fixed, 95\% CI) & $0.57[0.41,0.79]$ \\
\hline
\end{tabular}


Comparison 8. Oxytocin versus ergot alkaloids (randomised trials only)

\begin{tabular}{|c|c|c|c|c|}
\hline Outcome or subgroup title & $\begin{array}{l}\text { No. of } \\
\text { studies }\end{array}$ & $\begin{array}{c}\text { No. of } \\
\text { participants }\end{array}$ & Statistical method & Effect size \\
\hline $\begin{array}{l}1 \mathrm{PPH} \text { (clinically estimated blood } \\
\quad \text { loss }>\text { or }=500 \mathrm{ml} \text { ) }\end{array}$ & 3 & 1660 & Risk Ratio (M-H, Fixed, 95\% CI) & $1.03[0.73,1.47]$ \\
\hline $\begin{array}{l}2 \text { Severe PPH (clinically estimated } \\
\quad \text { blood loss }>\text { or }=1000 \mathrm{ml} \text { ) }\end{array}$ & 2 & 697 & Risk Ratio (M-H, Fixed, 95\% CI) & $1.09[0.45,2.66]$ \\
\hline 3 Mean blood loss $(\mathrm{ml})$ & 1 & 224 & Mean Difference (IV, Fixed, 95\% CI) & $\begin{array}{l}23.0[-91.86,137 . \\
86]\end{array}$ \\
\hline 5 Blood transfusion & 1 & 224 & Risk Ratio (M-H, Fixed, 95\% CI) & $3.74[0.34,40.64]$ \\
\hline 7 Therapeutic uterontonics & 2 & 1208 & Risk Ratio (M-H, Fixed, 95\% CI) & $1.02[0.67,1.55]$ \\
\hline 8 Third stage $>20$ minutes & 1 & 473 & Risk Ratio (M-H, Fixed, 95\% CI) & Not estimable \\
\hline 9 Third stage $>40$ minutes & 1 & 473 & Risk Ratio (M-H, Fixed, 95\% CI) & Not estimable \\
\hline 11 Manual removal of the placenta & 2 & 697 & Risk Ratio (M-H, Fixed, 95\% CI) & $0.71[0.49,1.02]$ \\
\hline
\end{tabular}

\section{Comparison 10. Oxytocin versus ergot alkaloids (expectant management only)}

\begin{tabular}{|c|c|c|c|c|}
\hline Outcome or subgroup title & $\begin{array}{l}\text { No. of } \\
\text { studies }\end{array}$ & $\begin{array}{c}\text { No. of } \\
\text { participants }\end{array}$ & Statistical method & Effect size \\
\hline $\begin{array}{l}1 \mathrm{PPH} \text { (clinically estimated blood } \\
\quad \text { loss }>\text { or }=500 \mathrm{ml} \text { ) }\end{array}$ & 1 & 224 & Risk Ratio (M-H, Fixed, 95\% CI) & $0.87[0.59,1.28]$ \\
\hline $\begin{array}{l}2 \text { Severe PPH (clinically estimated } \\
\quad \text { blood loss }>\text { or }=1000 \mathrm{ml} \text { ) }\end{array}$ & 1 & 224 & Risk Ratio (M-H, Fixed, 95\% CI) & $1.09[0.45,2.66]$ \\
\hline 3 Mean blood loss $(\mathrm{ml})$ & 1 & 224 & Mean Difference (IV, Fixed, 95\% CI) & $\begin{array}{l}23.0[-91.86,137 . \\
86]\end{array}$ \\
\hline 5 Blood transfusion & 1 & 224 & Risk Ratio (M-H, Fixed, 95\% CI) & $3.74[0.34,40.64]$ \\
\hline 7 Therapeutic uterontonics & 1 & 224 & Risk Ratio (M-H, Fixed, 95\% CI) & $1.25[0.67,2.31]$ \\
\hline 11 Manual removal of the placenta & 1 & 224 & Risk Ratio (M-H, Fixed, 95\% CI) & $0.94[0.09,10.16]$ \\
\hline
\end{tabular}


Comparison 11. Oxytocin versus ergot alkaloids (given before placental delivery)

\begin{tabular}{|c|c|c|c|c|}
\hline Outcome or subgroup title & $\begin{array}{l}\text { No. of } \\
\text { studies }\end{array}$ & $\begin{array}{c}\text { No. of } \\
\text { participants }\end{array}$ & Statistical method & Effect size \\
\hline $\begin{array}{l}1 \mathrm{PPH} \text { (clinically estimated blood } \\
\quad \text { loss }>\text { or }=500 \mathrm{ml} \text { ) }\end{array}$ & 4 & 1756 & Risk Ratio (M-H, Fixed, 95\% CI) & $0.83[0.64,1.08]$ \\
\hline $\begin{array}{l}2 \text { Severe PPH (clinically estimated } \\
\text { blood loss }>\text { or }=1000 \mathrm{ml} \text { ) }\end{array}$ & 3 & 1746 & Risk Ratio (M-H, Fixed, 95\% CI) & $0.99[0.56,1.74]$ \\
\hline 3 Mean blood loss $(\mathrm{ml})$ & 2 & 1273 & Mean Difference (IV, Fixed, 95\% CI) & $\begin{array}{l}-29.12[-59.36,1 \\
12]\end{array}$ \\
\hline 5 Blood transfusion & 1 & 224 & Risk Ratio (M-H, Fixed, 95\% CI) & $3.74[0.34,40.64]$ \\
\hline 7 Therapeutic uterontonics & 1 & 224 & Risk Ratio (M-H, Fixed, 95\% CI) & $1.25[0.67,2.31]$ \\
\hline 8 Third stage $>20$ minutes & 1 & 473 & Risk Ratio (M-H, Fixed, 95\% CI) & Not estimable \\
\hline 9 Third stage $>40$ minutes & 1 & 473 & Risk Ratio (M-H, Fixed, 95\% CI) & Not estimable \\
\hline $\begin{array}{l}10 \text { Mean length of third stage } \\
\text { (minutes) }\end{array}$ & 1 & 1049 & Mean Difference (IV, Fixed, 95\% CI) & $-0.80[-1.65,0.05]$ \\
\hline 11 Manual removal of the placenta & 3 & 1746 & Risk Ratio (M-H, Fixed, 95\% CI) & $0.57[0.41,0.79]$ \\
\hline $\begin{array}{l}13 \text { Diastolic blood pressure }>100 \\
\mathrm{~mm} \mathrm{Hg} \text { between delivery of the } \\
\text { baby and discharge from the } \\
\text { labour ward }\end{array}$ & 1 & 150 & Risk Ratio (M-H, Fixed, 95\% CI) & $0.53[0.19,1.52]$ \\
\hline
\end{tabular}

Comparison 12. Oxytocin versus ergot alkaloids (given after placental delivery)

\begin{tabular}{lcccc} 
Outcome or subgroup title & $\begin{array}{c}\text { No. of } \\
\text { studies }\end{array}$ & $\begin{array}{c}\text { No. of } \\
\text { participants }\end{array}$ & Statistical method & Effect size \\
\hline $\begin{array}{l}1 \text { PPH (clinically estimated blood } \\
\text { loss }>\text { or }=500 \mathrm{ml})\end{array}$ & 1 & 963 & Risk Ratio (M-H, Fixed, 95\% CI) & $1.75[0.77,3.96]$ \\
7 Therapeutic uterontonics & 1 & 984 & Risk Ratio (M-H, Fixed, 95\% CI) & $0.89[0.50,1.56]$ \\
\hline
\end{tabular}

Comparison 13. Oxytocin + ergometrine versus ergot alkaloids alone (all trials)

\begin{tabular}{|c|c|c|c|c|}
\hline Outcome or subgroup title & $\begin{array}{l}\text { No. of } \\
\text { studies }\end{array}$ & $\begin{array}{c}\text { No. of } \\
\text { participants }\end{array}$ & Statistical method & Effect size \\
\hline $\begin{array}{l}1 \mathrm{PPH} \text { (clinically estimated blood } \\
\quad \text { loss }>\text { or }=500 \mathrm{ml} \text { ) }\end{array}$ & 5 & 2891 & Risk Ratio (M-H, Fixed, 95\% CI) & $1.29[0.90,1.84]$ \\
\hline $\begin{array}{l}2 \text { Severe PPH (clinically estimated } \\
\quad \text { blood loss }>\text { or }=1000 \mathrm{ml} \text { ) }\end{array}$ & 1 & 1120 & Risk Ratio (M-H, Fixed, 95\% CI) & $1.67[0.40,6.94]$ \\
\hline 5 Blood transfusion & 1 & 1120 & Risk Ratio (M-H, Fixed, 95\% CI) & $0.71[0.23,2.24]$ \\
\hline 8 Third stage $>20$ minutes & 3 & 2281 & Risk Ratio (M-H, Fixed, 95\% CI) & $0.89[0.67,1.19]$ \\
\hline 11 Manual removal of the placenta & 2 & 1927 & Risk Ratio (M-H, Fixed, 95\% CI) & $1.02[0.48,2.20]$ \\
\hline
\end{tabular}


Comparison 14. Oxytocin + ergometrine versus ergot alkaloids alone (randomised trials)

\begin{tabular}{lcccc} 
Outcome or subgroup title & $\begin{array}{c}\text { No. of } \\
\text { studies }\end{array}$ & $\begin{array}{c}\text { No. of } \\
\text { participants }\end{array}$ & Statistical method & Effect size \\
\hline $\begin{array}{l}1 \text { PPH (clinically estimated blood } \\
\text { loss }>\text { or }=500 \mathrm{ml})\end{array}$ & 2 & 1161 & Risk Ratio (M-H, Fixed, 95\% CI) & $0.44[0.20,0.94]$ \\
8 Third stage $>20$ minutes & 1 & 354 & Risk Ratio (M-H, Fixed, 95\% CI) & $3.21[0.34,30.57]$ \\
\hline
\end{tabular}

Comparison 15. Oxytocin + ergometrine versus ergot alkaloids alone (active management)

\begin{tabular}{|c|c|c|c|c|}
\hline Outcome or subgroup title & $\begin{array}{l}\text { No. of } \\
\text { studies }\end{array}$ & $\begin{array}{c}\text { No. of } \\
\text { participants }\end{array}$ & Statistical method & Effect size \\
\hline $\begin{array}{l}1 \mathrm{PPH} \text { (clinically estimated blood } \\
\quad \text { loss }>\text { or }=500 \mathrm{ml} \text { ) }\end{array}$ & 1 & 416 & Risk Ratio (M-H, Fixed, 95\% CI) & $0.22[0.03,1.85]$ \\
\hline 8 Third stage $>20$ minutes & 1 & 416 & Risk Ratio (M-H, Fixed, 95\% CI) & $6.54[0.79,53.87]$ \\
\hline 11 Manual removal of the placenta & 1 & 416 & Risk Ratio (M-H, Fixed, 95\% CI) & $4.36[0.49,38.70]$ \\
\hline
\end{tabular}

Comparison 17. Oxytocin + ergometrine versus ergot alkaloids alone (given before placental delivery

\begin{tabular}{|c|c|c|c|c|}
\hline Outcome or subgroup title & $\begin{array}{l}\text { No. of } \\
\text { studies }\end{array}$ & $\begin{array}{c}\text { No. of } \\
\text { participants }\end{array}$ & Statistical method & Effect size \\
\hline $\begin{array}{l}1 \mathrm{PPH} \text { (clinically estimated blood } \\
\text { loss }>\text { or }=500 \mathrm{ml} \text { ) }\end{array}$ & 5 & 2891 & Risk Ratio (M-H, Fixed, 95\% CI) & $1.29[0.90,1.84]$ \\
\hline $\begin{array}{l}2 \text { Severe PPH (clinically estimated } \\
\quad \text { blood loss }>\text { or }=1000 \mathrm{ml} \text { ) }\end{array}$ & 1 & 1120 & Risk Ratio (M-H, Fixed, 95\% CI) & $1.67[0.40,6.94]$ \\
\hline 5 Blood transfusion & 1 & 1120 & Risk Ratio (M-H, Fixed, 95\% CI) & $0.71[0.23,2.24]$ \\
\hline 8 Third stage $>20$ minutes & 3 & 2281 & Risk Ratio (M-H, Fixed, 95\% CI) & $0.89[0.67,1.19]$ \\
\hline 11 Manual removal of the placenta & 2 & 1927 & Risk Ratio (M-H, Fixed, 95\% CI) & $1.02[0.48,2.20]$ \\
\hline
\end{tabular}


Analysis I.I. Comparison I Oxytocin versus no uterotonics (all trials), Outcome I PPH (clinically estimated blood loss $>$ or $=500 \mathrm{ml}$ ).

\begin{tabular}{|c|c|c|c|c|c|}
\hline \multicolumn{6}{|c|}{ Comparison: I Oxytocin versus no uterotonics (all trials) } \\
\hline \multicolumn{6}{|c|}{ Outcome: I PPH (clinically estimated blood loss $>$ or $=500 \mathrm{ml}$ ) } \\
\hline \multirow[t]{2}{*}{ Study or subgroup } & Oxytocin & Control & Risk Ratio & Weight & Risk Ratio \\
\hline & $\mathrm{n} / \mathrm{N}$ & $n / N$ & M-H,Fixed,95\% Cl & & M-H,Fixed,95\% Cl \\
\hline De Groot 1996 & $25 / 78$ & $55 / 143$ & $\rightarrow$ & $10.2 \%$ & $0.83[0.57,1.22]$ \\
\hline Howard 1964 & $15 / 470$ & $25 / 470$ & $\longrightarrow$ & $6.6 \%$ & $0.60[0.32,1.12]$ \\
\hline llancheran 1990 & $0 / 5$ & $0 / 5$ & & & Not estimable \\
\hline Nordstrom 1997 & $104 / 513$ & 175/487 & : & $47.1 \%$ & $0.56[0.46,0.70]$ \\
\hline Pierre 1992 & $37 / 488$ & $126 / 482$ & 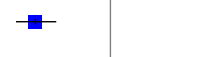 & $33.3 \%$ & $0.29[0.21,0.41]$ \\
\hline Poeschmann 1991 & $7 / 28$ & $10 / 24$ & $\longrightarrow$ & $2.8 \%$ & $0.60[0.27,1.33]$ \\
\hline Total $(95 \% \mathrm{CI})$ & 1582 & 1611 & $\bullet$ & $100.0 \%$ & $0.50[0.43,0.59]$ \\
\hline \multicolumn{6}{|c|}{ Total events: | 88 (Oxytocin), 39| (Control) } \\
\hline \multicolumn{6}{|c|}{ Heterogeneity: $\mathrm{Ch}^{2}=18.10, \mathrm{df}=4(\mathrm{P}=0.00 \mathrm{I}) ; \mathrm{I}^{2}=78 \%$} \\
\hline \multicolumn{6}{|c|}{ Test for overall effect: $Z=8.76(P<0.0000 \mathrm{I})$} \\
\hline
\end{tabular}


Analysis I.2. Comparison I Oxytocin versus no uterotonics (all trials), Outcome 2 Severe PPH (clinically estimated blood loss $>$ or $=1000 \mathrm{ml})$.

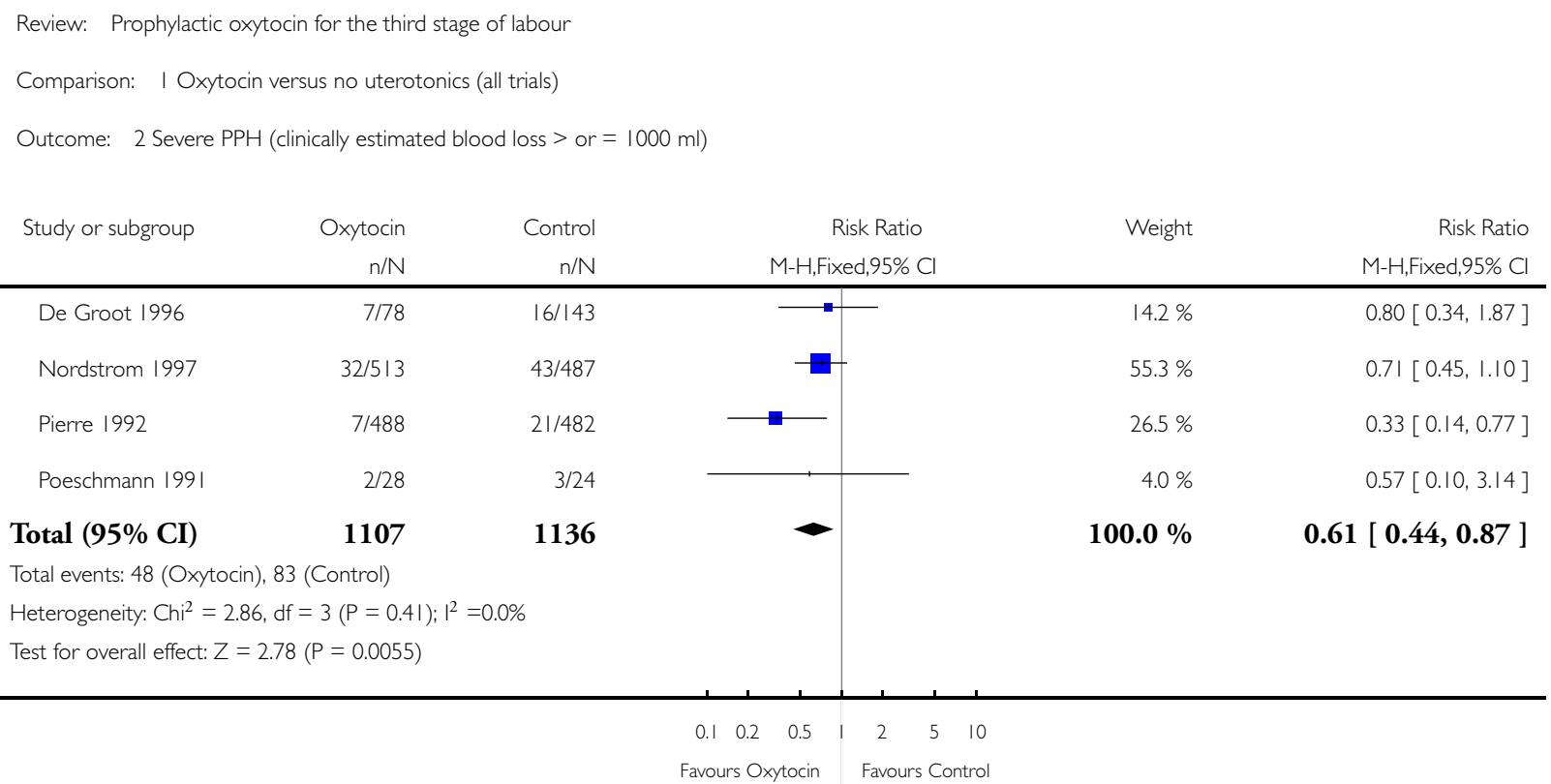


Analysis I.3. Comparison I Oxytocin versus no uterotonics (all trials), Outcome 3 Mean blood loss (ml).

Review: Prophylactic oxytocin for the third stage of labour

Comparison: I Oxytocin versus no uterotonics (all trials)

Outcome: 3 Mean blood loss $(\mathrm{ml})$

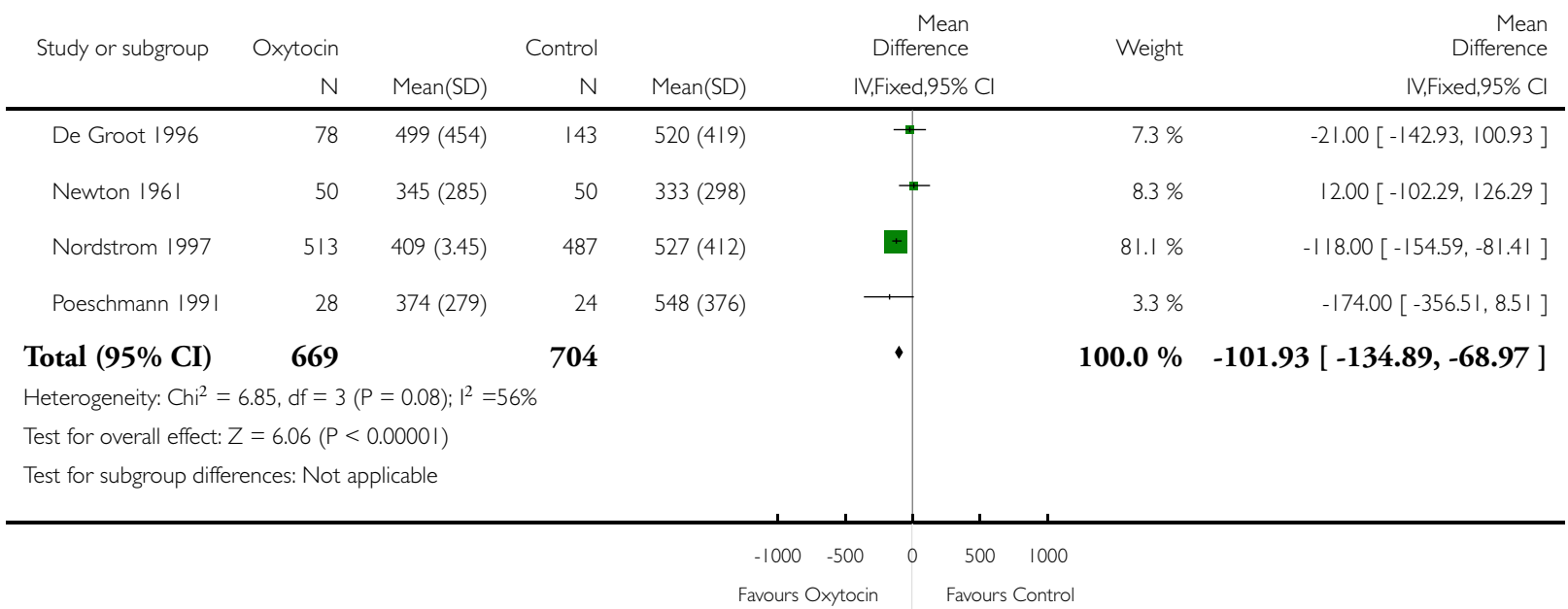

Analysis I.4. Comparison I Oxytocin versus no uterotonics (all trials), Outcome 4 Maternal haemoglobin concentration $(\mathrm{Hb})<9 \mathrm{gm} /$ deciltre 24 to 48 hours postpartum.

Review: Prophylactic oxytocin for the third stage of labour

Comparison: I Oxytocin versus no uterotonics (all trials)

Outcome: 4 Maternal haemoglobin concentration $(\mathrm{Hb})<9 \mathrm{gm} /$ deciltre 24 to 48 hours postpartum

\begin{tabular}{ccccc} 
Study or subgroup & Oxytocin & Control & Risk Ratio & Weight \\
& $\mathrm{n} / \mathrm{N}$ & $\mathrm{n} / \mathrm{N}$ & $\mathrm{M}-\mathrm{H}$, Fixed,95\% Cl & $\mathrm{M}-\mathrm{H}$, Fixed,95\% Cl \\
\hline Nordstrom 1997 & $20 / 485$ & $30 / 458$ & - & $100.0 \%$
\end{tabular}

Total $(95 \% \mathrm{CI})$

485

458

$100.0 \%$

$0.63[0.36,1.09]$

Total events: 20 (Oxytocin), 30 (Control)

Heterogeneity: not applicable

Test for overall effect: $Z=1.65(P=0.10)$

$\begin{array}{lllllll}0.1 & 0.2 & 0.5 & 1 & 2 & 5 & 10\end{array}$

Favours Oxytocin Favours Control

Copyright $₫ 2010$ The Cochrane Collaboration. Published by John Wiley \& Sons, Ltd. 


\section{Analysis I.5. Comparison I Oxytocin versus no uterotonics (all trials), Outcome 5 Blood transfusion.}

Review: Prophylactic oxytocin for the third stage of labour

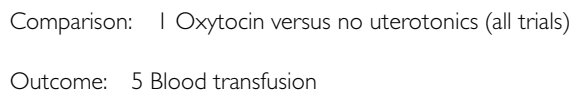

\begin{tabular}{|c|c|c|c|c|c|}
\hline & $\mathrm{n} / \mathrm{N}$ & $\mathrm{n} / \mathrm{N}$ & M-H,Fixed,95\% Cl & & M-H,Fixed,95\% Cl \\
\hline De Groot 1996 & $2 / 78$ & $3 / 143$ & 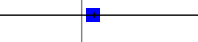 & $29.2 \%$ & $1.22[0.21,7.16]$ \\
\hline Nordstrom 1997 & $7 / 513$ & $5 / 487$ & 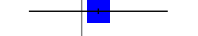 & $70.8 \%$ & $1.33[0.42,4.16]$ \\
\hline Total $(95 \%$ CI $)$ & 591 & 630 & & $100.0 \%$ & $1.30[0.50,3.39]$ \\
\hline \multicolumn{6}{|c|}{ Total events: 9 (Oxytocin), 8 (Control) } \\
\hline \multicolumn{6}{|c|}{ Heterogeneity: $\mathrm{Chi}^{2}=0.0 \mathrm{I}, \mathrm{df}=\mathrm{I}(\mathrm{P}=0.94) ; \mathrm{I}^{2}=0.0 \%$} \\
\hline \multicolumn{6}{|c|}{ Test for overall effect: $Z=0.53(P=0.59)$} \\
\hline
\end{tabular}




\section{Analysis I.7. Comparison I Oxytocin versus no uterotonics (all trials), Outcome 7 Therapeutic}

uterontonics.

Review: Prophylactic oxytocin for the third stage of labour

Comparison: I Oxytocin versus no uterotonics (all trials)

Outcome: 7 Therapeutic uterontonics

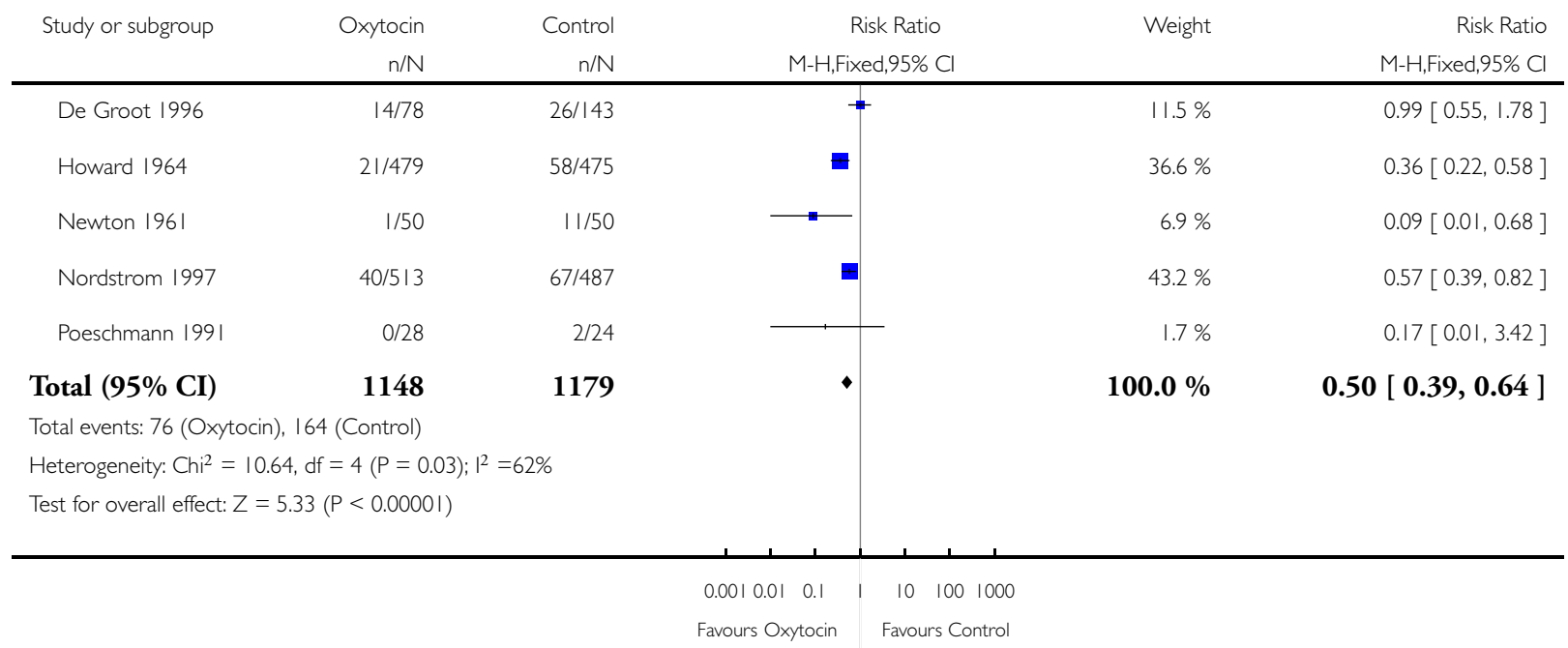


Analysis I.10. Comparison I Oxytocin versus no uterotonics (all trials), Outcome 10 Mean length of third stage (minutes).

Review: Prophylactic oxytocin for the third stage of labour

Comparison: I Oxytocin versus no uterotonics (all trials)

Outcome: 10 Mean length of third stage (minutes)

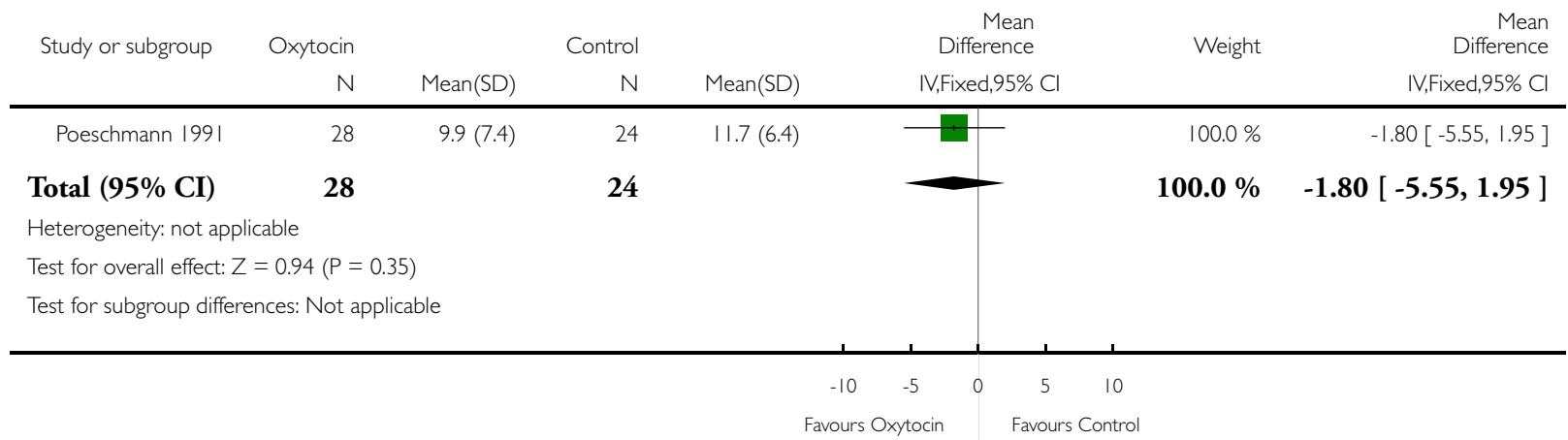

Analysis I.I I. Comparison I Oxytocin versus no uterotonics (all trials), Outcome I I Manual removal of the placenta.

Review: Prophylactic oxytocin for the third stage of labour

Comparison: I Oxytocin versus no uterotonics (all trials)

Outcome: II Manual removal of the placenta

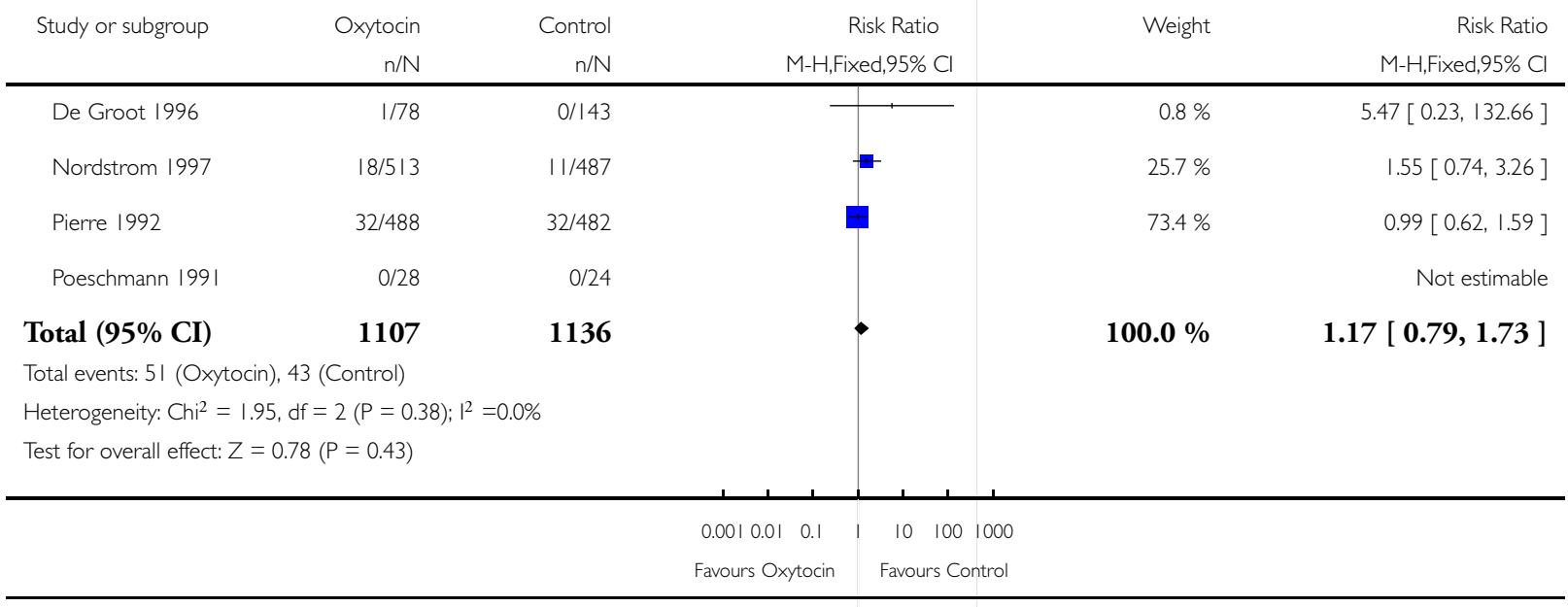

Prophylactic oxytocin for the third stage of labour (Review)

Copyright $\odot 2010$ The Cochrane Collaboration. Published by John Wiley \& Sons, Ltd. 
Analysis I.I5. Comparison I Oxytocin versus no uterotonics (all trials), Outcome I5 Nausea between delivery of the baby and discharge from the labour ward.

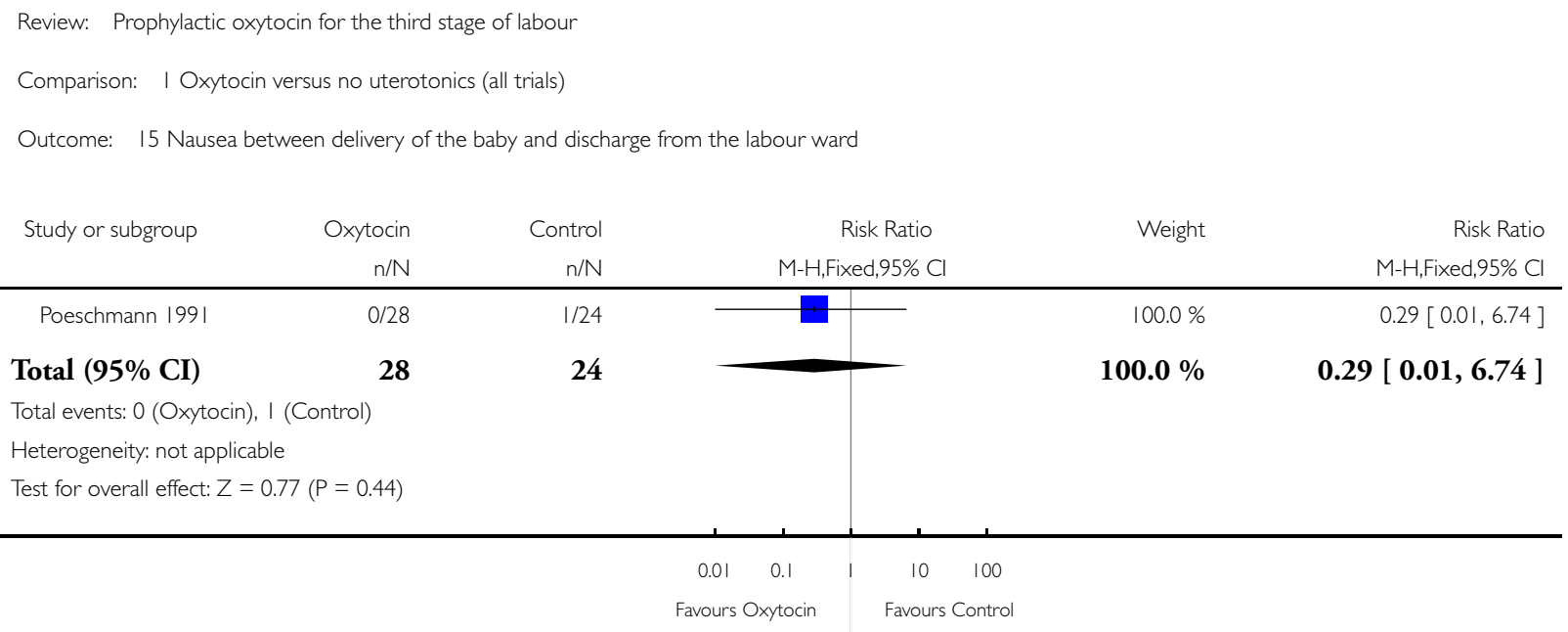


Analysis 2.I. Comparison 2 Oxytocin versus no uterotonics (randomised trials only), Outcome I PPH (clinically estimated blood loss $>$ or $=500 \mathrm{ml}$ ).

\begin{tabular}{|c|c|c|c|c|c|}
\hline \multicolumn{6}{|c|}{ Comparison: 2 Oxytocin versus no uterotonics (randomised trials only) } \\
\hline \multicolumn{6}{|c|}{ Outcome: I PPH (clinically estimated blood loss $>$ or $=500 \mathrm{ml}$ ) } \\
\hline \multirow[t]{2}{*}{ Study or subgroup } & Oxytocin & Control & Risk Ratio & Weight & Risk Ratio \\
\hline & $n / N$ & $\mathrm{n} / \mathrm{N}$ & M-H,Fixed,95\% Cl & & M-H,Fixed,95\% Cl \\
\hline De Groot 1996 & $25 / 78$ & $55 / 143$ & $\rightarrow$ & $15.3 \%$ & $0.83[0.57,1.22]$ \\
\hline Howard 1964 & $15 / 470$ & $25 / 470$ & $\longrightarrow$ & $9.8 \%$ & $0.60[0.32,1.12]$ \\
\hline Nordstrom 1997 & $104 / 513$ & 175/487 & 분 & $70.6 \%$ & $0.56[0.46,0.70]$ \\
\hline Poeschmann 1991 & $7 / 28$ & $10 / 24$ & + & $4.2 \%$ & $0.60[0.27,1.33]$ \\
\hline Total $(95 \% \mathrm{CI})$ & 1089 & 1124 & $\bullet$ & $100.0 \%$ & $0.61[0.51,0.72]$ \\
\hline \multicolumn{6}{|c|}{ Total events: 15I (Oxytocin), 265 (Control) } \\
\hline \multicolumn{6}{|c|}{ Heterogeneity: $\mathrm{Chi}^{2}=3.08, \mathrm{df}=3(\mathrm{P}=0.38) ; \mathrm{I}^{2}=3 \%$} \\
\hline \multicolumn{6}{|c|}{ Test for overall effect: $Z=5.62(P<0.0000 I)$} \\
\hline
\end{tabular}


Analysis 2.2. Comparison 2 Oxytocin versus no uterotonics (randomised trials only), Outcome 2 Severe PPH (clinically estimated blood loss $>$ or $=1000 \mathrm{ml}$ ).

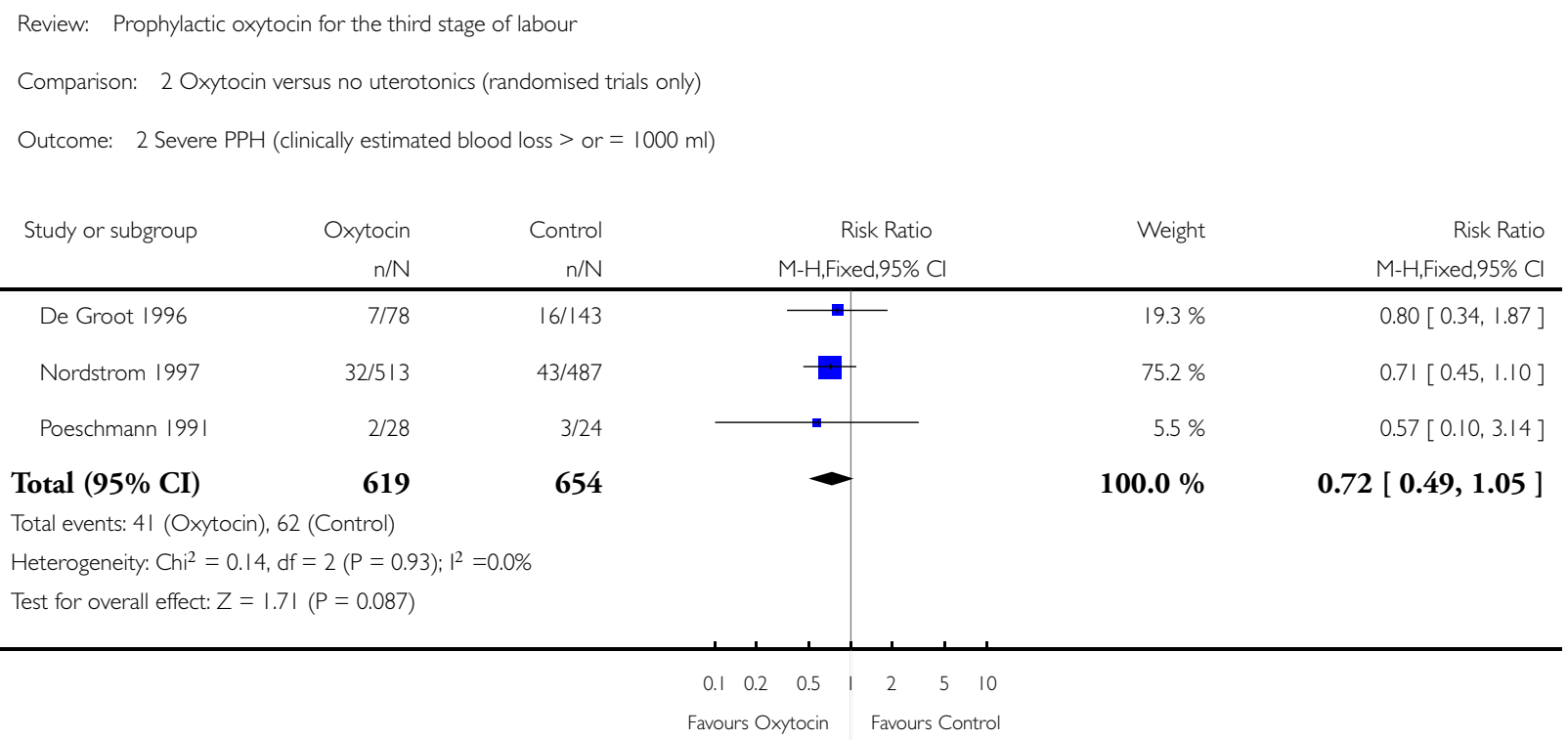


Analysis 2.3. Comparison 2 Oxytocin versus no uterotonics (randomised trials only), Outcome 3 Mean blood loss $(\mathrm{ml})$.

Review: Prophylactic oxytocin for the third stage of labour

Comparison: 2 Oxytocin versus no uterotonics (randomised trials only)

Outcome: 3 Mean blood loss $(\mathrm{ml})$

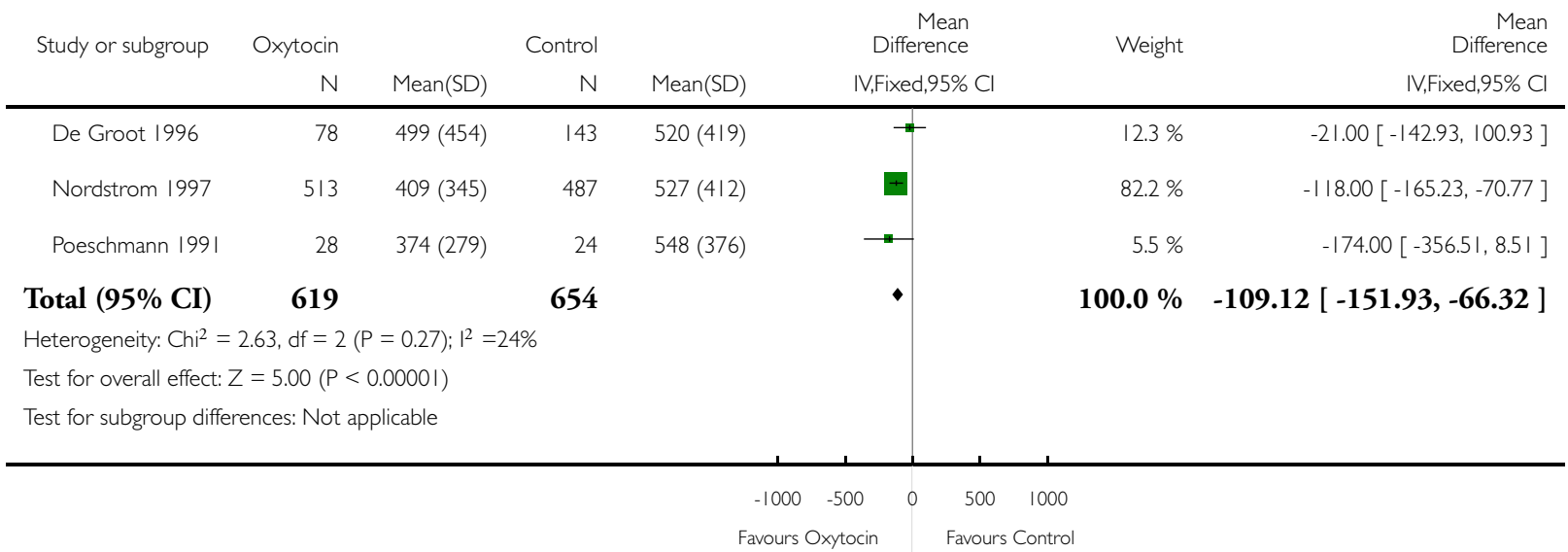

Analysis 2.4. Comparison 2 Oxytocin versus no uterotonics (randomised trials only), Outcome 4 Maternal haemoglobin concentration $(\mathrm{Hb})<9 \mathrm{gm} /$ deciltre 24 to 48 hours postpartum.

Review: Prophylactic oxytocin for the third stage of labour

Comparison: 2 Oxytocin versus no uterotonics (randomised trials only)

Outcome: 4 Maternal haemoglobin concentration $(\mathrm{Hb})<9 \mathrm{gm} /$ deciltre 24 to 48 hours postpartum

\begin{tabular}{|c|c|c|c|c|c|}
\hline \multirow[t]{2}{*}{ Study or subgroup } & Oxytocin & Control & Risk Ratio & Weight & Risk Ratio \\
\hline & $\mathrm{n} / \mathrm{N}$ & $\mathrm{n} / \mathrm{N}$ & M-H,Fixed,95\% Cl & & M-H,Fixed,95\% Cl \\
\hline Nordstrom 1997 & $20 / 485$ & $30 / 458$ & & $100.0 \%$ & $0.63[0.36,1.09]$ \\
\hline
\end{tabular}

Total (95\% CI)

485

458

$100.0 \%$

$0.63[0.36,1.09]$

Total events: 20 (Oxytocin), 30 (Control)

Heterogeneity: not applicable

Test for overall effect: $Z=1.65(P=0.10)$

$\begin{array}{lllllll}0.1 & 0.2 & 0.5 & 1 & 2 & 5 & 10\end{array}$

Favours Oxytocin Favours Control 


\section{Analysis 2.5. Comparison 2 Oxytocin versus no uterotonics (randomised trials only), Outcome 5 Blood}

transfusion.

\begin{tabular}{|c|c|c|c|c|c|}
\hline \multicolumn{6}{|c|}{ Comparison: 2 Oxytocin versus no uterotonics (randomised trials only) } \\
\hline Outcome: 5 Blood & & & & & \\
\hline \multirow[t]{2}{*}{ Study or subgroup } & Oxytocin & Control & Risk Ratio & Weight & Risk Ratio \\
\hline & $n / N$ & $\mathrm{n} / \mathrm{N}$ & \multicolumn{2}{|l|}{ M-H,Fixed,95\% Cl } & M-H,Fixed,95\% Cl \\
\hline De Groot 1996 & $2 / 78$ & $3 / 143$ & + & $29.2 \%$ & $1.22[0.21,7.16]$ \\
\hline Nordstrom 1997 & $7 / 513$ & $5 / 487$ & + & $70.8 \%$ & $1.33[0.42,4.16]$ \\
\hline Total (95\% CI) & 591 & 630 & & $100.0 \%$ & $1.30[0.50,3.39]$ \\
\hline \multicolumn{6}{|c|}{ Total events: 9 (Oxytocin), 8 (Control) } \\
\hline \multicolumn{6}{|c|}{ Heterogeneity: $\mathrm{Chi}^{2}=0.0 \mathrm{I}, \mathrm{df}=\mathrm{I}(\mathrm{P}=0.94) ; \mathrm{I}^{2}=0.0 \%$} \\
\hline \multicolumn{6}{|c|}{ Test for overall effect: $Z=0.53(P=0.59)$} \\
\hline
\end{tabular}


Analysis 2.7. Comparison 2 Oxytocin versus no uterotonics (randomised trials only), Outcome 7

Therapeutic uterontonics.

\begin{tabular}{|c|c|c|c|c|c|}
\hline \multicolumn{6}{|c|}{ Review: Prophylactic oxytocin for the third stage of labour } \\
\hline \multicolumn{6}{|c|}{ Comparison: 2 Oxytocin versus no uterotonics (randomised trials only) } \\
\hline \multicolumn{6}{|c|}{ Outcome: 7 Therapeutic uterontonics } \\
\hline \multirow[t]{2}{*}{ Study or subgroup } & Oxytocin & Control & Risk Ratio & Weight & Risk Ratio \\
\hline & $\mathrm{n} / \mathrm{N}$ & $\mathrm{n} / \mathrm{N}$ & M-H,Fixed,95\% Cl & & M-H,Fixed,95\% Cl \\
\hline De Groot 1996 & $14 / 78$ & $26 / 143$ & + & $12.4 \%$ & $0.99[0.55,1.78]$ \\
\hline Howard 1964 & $21 / 479$ & $58 / 475$ & = & $39.3 \%$ & $0.36[0.22,0.58]$ \\
\hline Nordstrom 1997 & $40 / 513$ & $67 / 487$ & $\mathbf{\square}$ & $46.4 \%$ & $0.57[0.39,0.82]$ \\
\hline Poeschmann 199| & $0 / 28$ & $2 / 24$ & - & $1.8 \%$ & $0.17[0.01,3.42]$ \\
\hline Total $(95 \% \mathrm{CI})$ & 1098 & 1129 & - & $100.0 \%$ & $0.53[0.41,0.69]$ \\
\hline \multicolumn{6}{|c|}{ Total events: 75 (Oxytocin), 153 (Control) } \\
\hline \multicolumn{6}{|c|}{ Heterogeneity: $\mathrm{Ch}^{2}=7.46, \mathrm{df}=3(\mathrm{P}=0.06) ; \mathrm{I}^{2}=60 \%$} \\
\hline \multicolumn{6}{|c|}{ Test for overall effect: $Z=4.80(P<0.0000 I)$} \\
\hline
\end{tabular}

Analysis 2.10. Comparison 2 Oxytocin versus no uterotonics (randomised trials only), Outcome 10 Mean length of third stage (minutes).

Review: Prophylactic oxytocin for the third stage of labour

Comparison: 2 Oxytocin versus no uterotonics (randomised trials only)

Outcome: 10 Mean length of third stage (minutes)

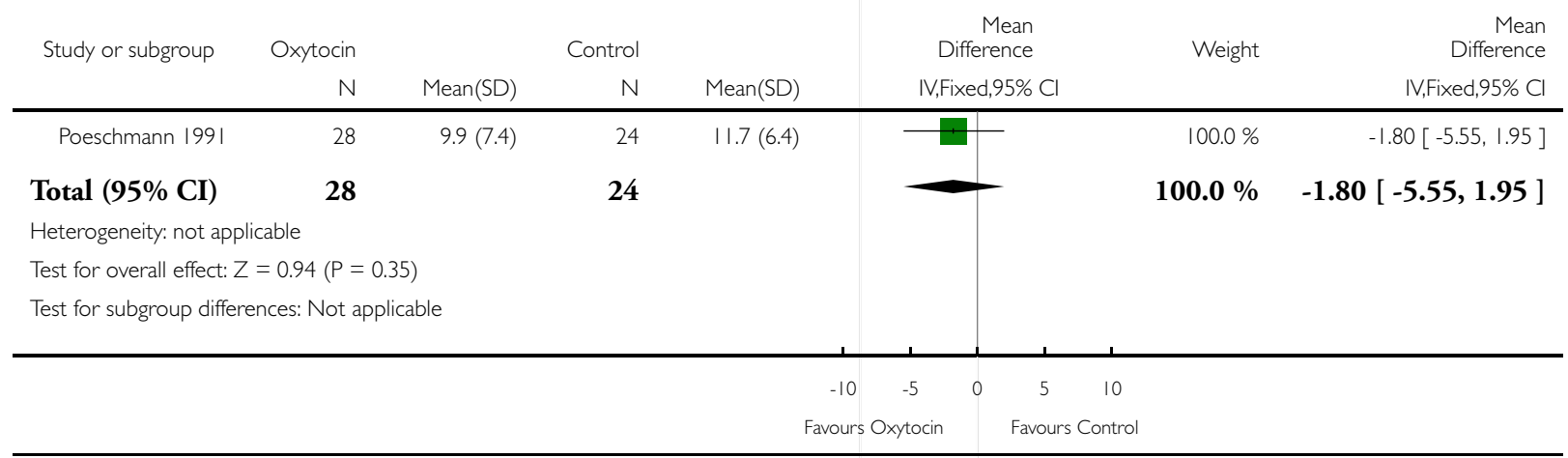

Prophylactic oxytocin for the third stage of labour (Review)

Copyright () 2010 The Cochrane Collaboration. Published by John Wiley \& Sons, Ltd. 
Analysis 2.1 I. Comparison 2 Oxytocin versus no uterotonics (randomised trials only), Outcome II Manual removal of the placenta.

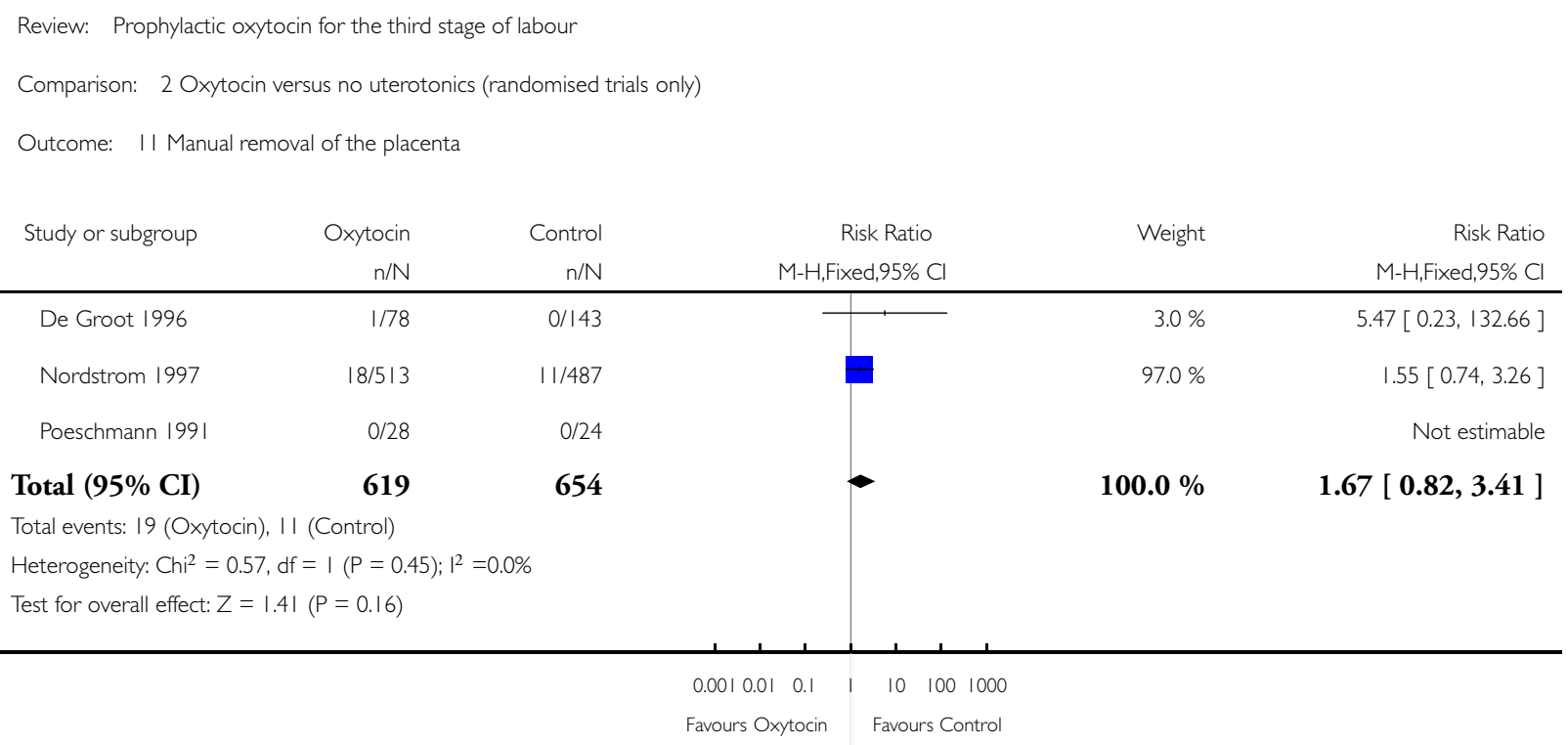


Analysis 2.15. Comparison 2 Oxytocin versus no uterotonics (randomised trials only), Outcome 15 Nausea between delivery of the baby and discharge from the labour ward.

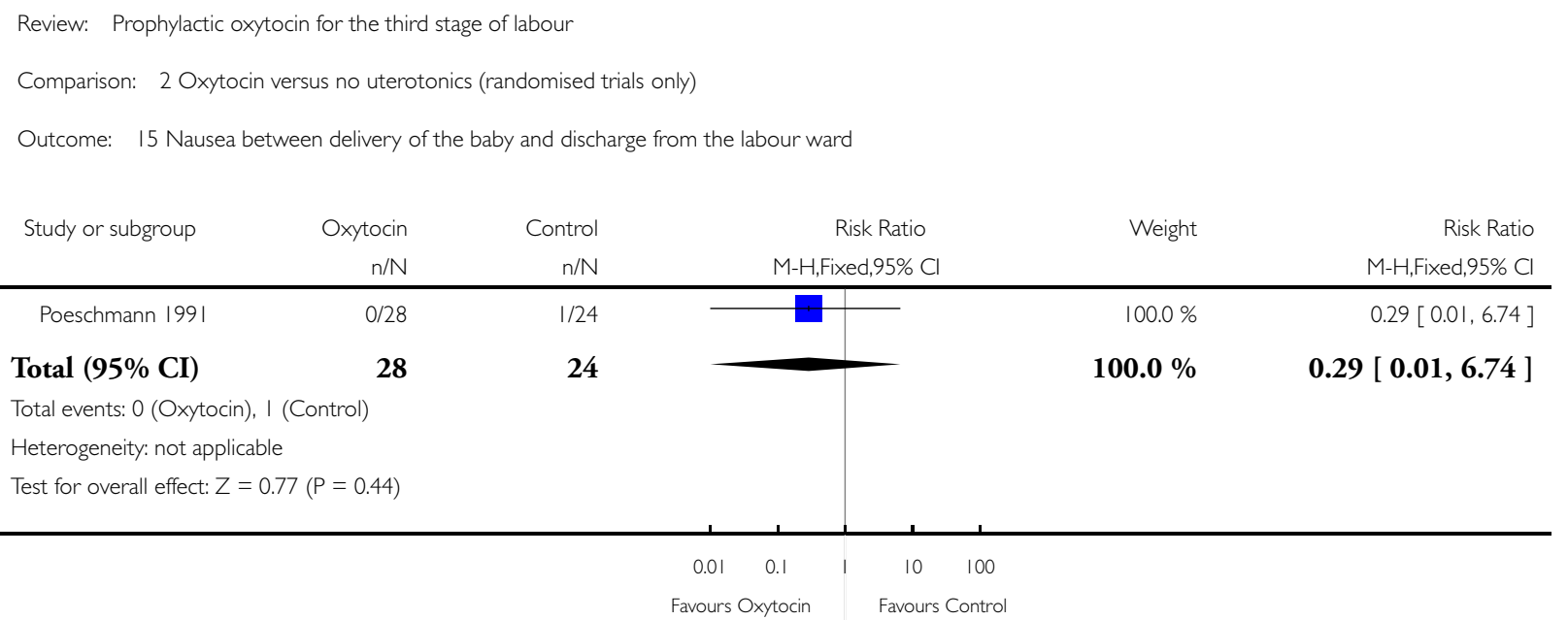

\section{Analysis 3.I. Comparison 3 Oxytocin versus no uterotonics (active management only), Outcome I PPH} (clinically estimated blood loss $>$ or $=500 \mathrm{ml}$ ).

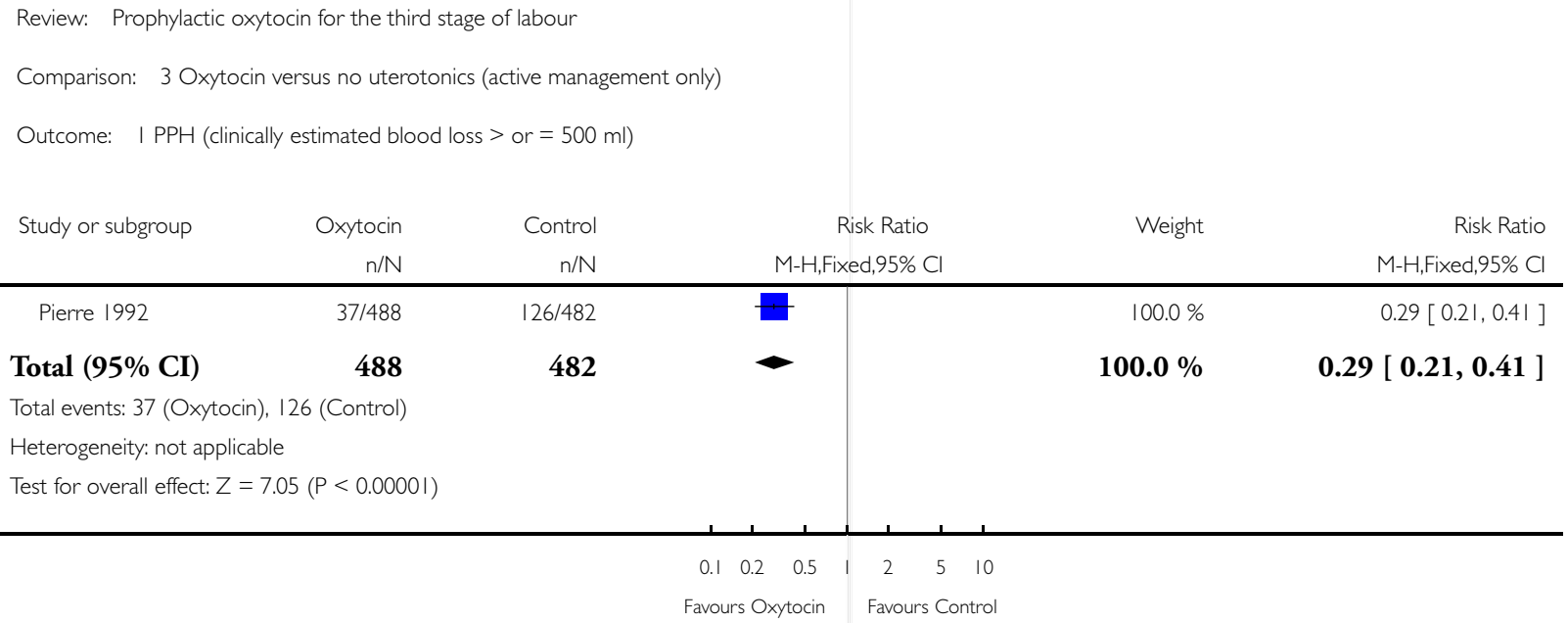


Analysis 3.2. Comparison 3 Oxytocin versus no uterotonics (active management only), Outcome 2 Severe PPH (clinically estimated blood loss $>$ or $=1000 \mathrm{ml}$ ).

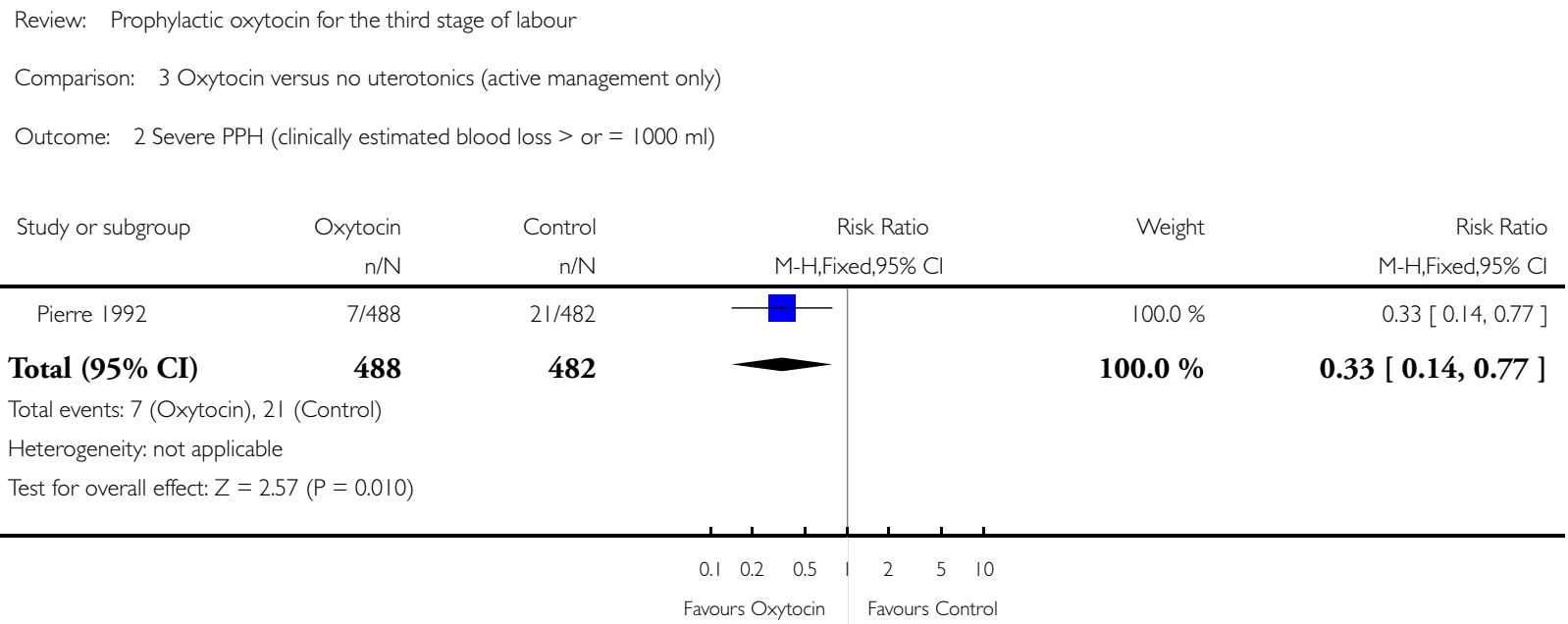

\section{Analysis 3.I I. Comparison 3 Oxytocin versus no uterotonics (active management only), Outcome I I} Manual removal of the placenta.

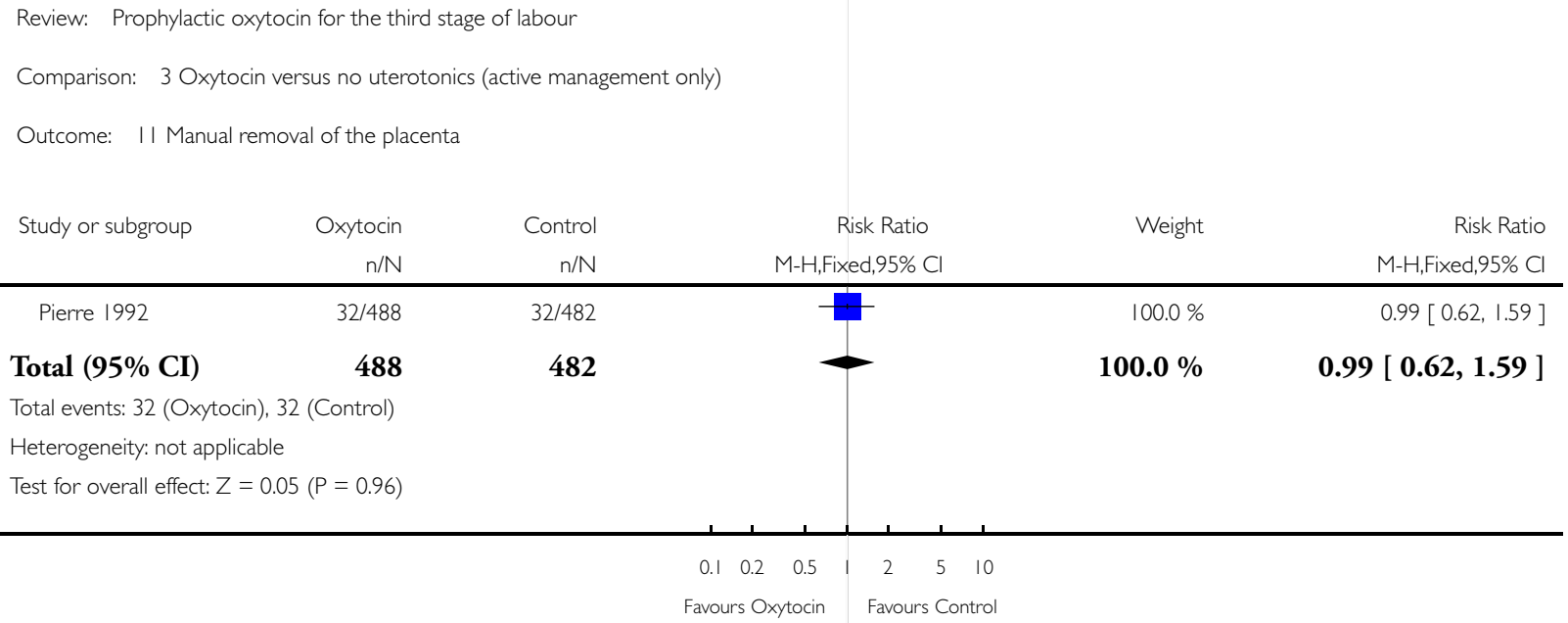


Analysis 4.I. Comparison 4 Oxytocin versus no uterotonics (expectant management only), Outcome I PPH (clinically estimated blood loss $>$ or $=500 \mathrm{ml}$ ).

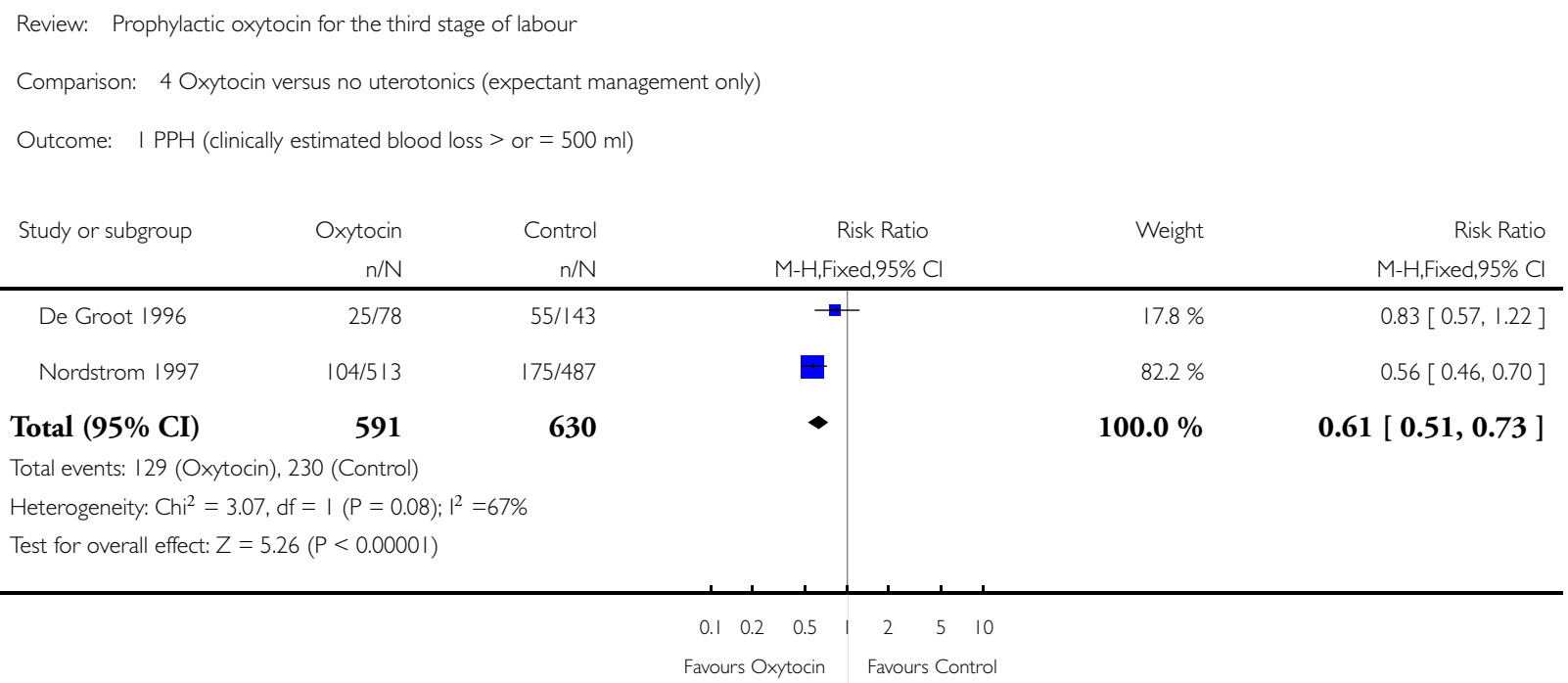

\section{Analysis 4.2. Comparison 4 Oxytocin versus no uterotonics (expectant management only), Outcome 2} Severe PPH (clinically estimated blood loss $>$ or $=1000 \mathrm{ml})$.

Review: Prophylactic oxytocin for the third stage of labour

Comparison: 4 Oxytocin versus no uterotonics (expectant management only)

Outcome: 2 Severe PPH (clinically estimated blood loss $>$ or $=1000 \mathrm{ml}$ )

\begin{tabular}{|c|c|c|c|c|c|}
\hline \multirow[t]{2}{*}{ Study or subgroup } & Oxytocin & Control & Risk Ratio & Weight & Risk Ratio \\
\hline & $\mathrm{n} / \mathrm{N}$ & $\mathrm{n} / \mathrm{N}$ & M-H,Fixed,95\% Cl & & M-H,Fixed,95\% Cl \\
\hline De Groot 1996 & $7 / 78$ & $16 / 143$ & $\longrightarrow$ & $20.4 \%$ & $0.80[0.34,1.87]$ \\
\hline Nordstrom 1997 & $32 / 513$ & $43 / 487$ & & $79.6 \%$ & $0.71[0.45,1.10]$ \\
\hline Total (95\% CI) & 591 & 630 & $\longrightarrow$ & $00.0 \%$ & $3[0.49,1.07]$ \\
\hline
\end{tabular}

Total events: 39 (Oxytocin), 59 (Control)

Heterogeneity: Chi $^{2}=0.07, \mathrm{df}=\mathrm{I}(\mathrm{P}=0.79) ; \mathrm{I}^{2}=0.0 \%$

Test for overall effect: $Z=1.61(P=0.1 \mathrm{I})$

$\begin{array}{lllllll}0.1 & 0.2 & 0.5 & 1 & 2 & 5 & 10\end{array}$

Favours Oxytocin Favours Control 
Analysis 4.3. Comparison 4 Oxytocin versus no uterotonics (expectant management only), Outcome 3 Mean blood loss ( $\mathrm{ml})$.

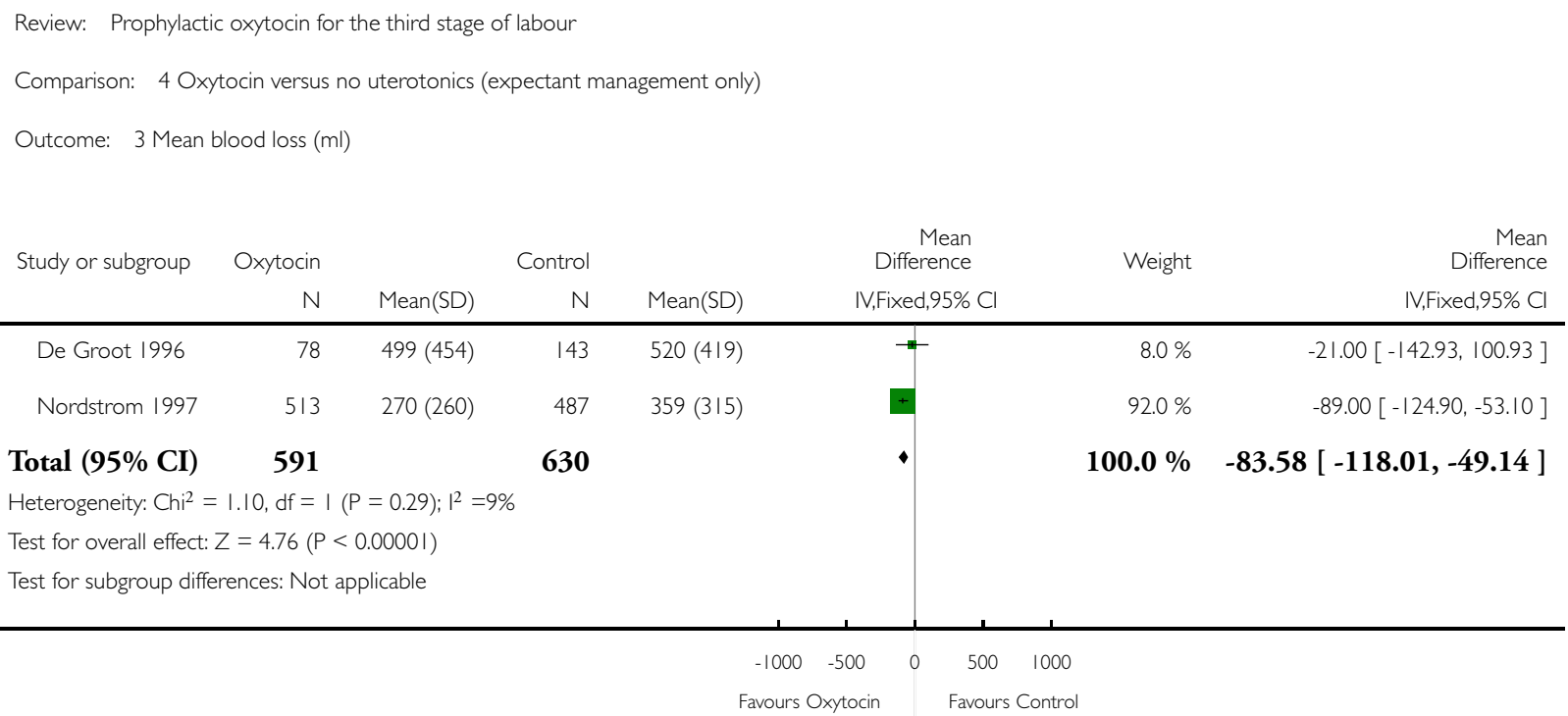

Analysis 4.4. Comparison 4 Oxytocin versus no uterotonics (expectant management only), Outcome 4 Maternal haemoglobin concentration $(\mathrm{Hb})<9 \mathrm{gm} /$ deciltre 24 to 48 hours postpartum.

Review: Prophylactic oxytocin for the third stage of labour

Comparison: 4 Oxytocin versus no uterotonics (expectant management only)

Outcome: 4 Maternal haemoglobin concentration $(\mathrm{Hb})<9 \mathrm{gm} /$ deciltre 24 to 48 hours postpartum

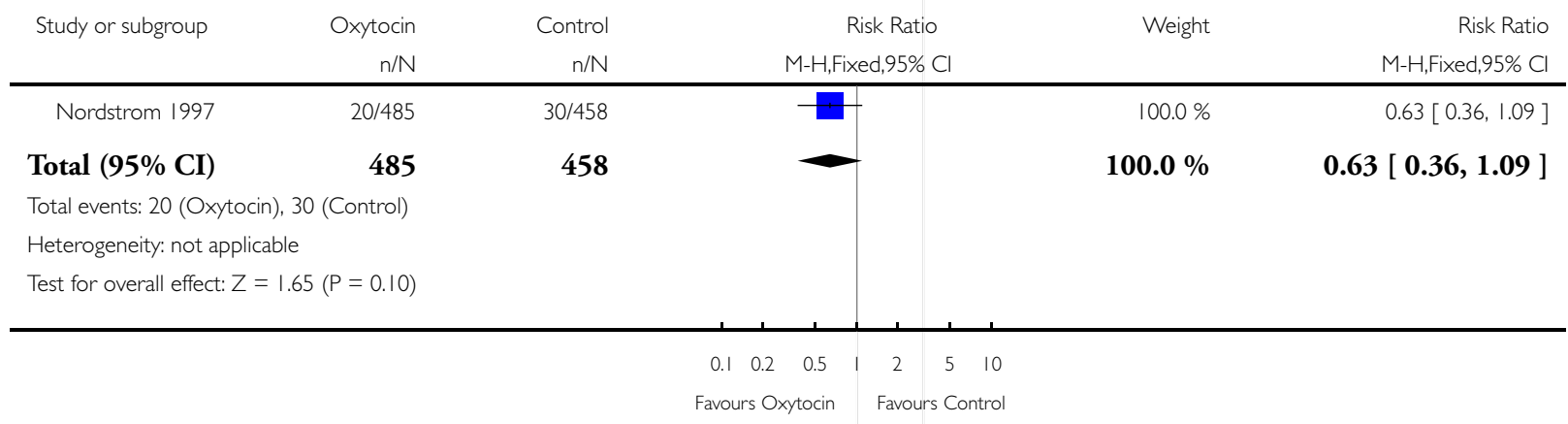


Analysis 4.5. Comparison 4 Oxytocin versus no uterotonics (expectant management only), Outcome 5 Blood transfusion.

\begin{tabular}{|c|c|c|c|c|c|}
\hline \multicolumn{6}{|c|}{ Comparison: 4 Oxytocin versus no uterotonics (expectant management only) } \\
\hline \multicolumn{6}{|c|}{ Outcome: 5 Blood transfusion } \\
\hline \multirow[t]{2}{*}{ Study or subgroup } & Oxytocin & Control & Risk Ratio & \multirow[t]{2}{*}{ Weight } & Risk Ratio \\
\hline & $n / N$ & $\mathrm{n} / \mathrm{N}$ & M-H,Fixed,95\% Cl & & M-H,Fixed,95\% Cl \\
\hline De Groot 1996 & $2 / 78$ & $3 / 143$ & $\rightarrow-$ & $29.2 \%$ & $1.22[0.21,7.16]$ \\
\hline Nordstrom 1997 & $7 / 513$ & $5 / 487$ & + & $70.8 \%$ & $1.33[0.42,4.16]$ \\
\hline Total $(95 \% \mathrm{CI})$ & 591 & 630 & & $100.0 \%$ & $1.30[0.50,3.39]$ \\
\hline \multicolumn{6}{|c|}{ Total events: 9 (Oxytocin), 8 (Control) } \\
\hline \multicolumn{6}{|c|}{ Heterogeneity: $\mathrm{Ch}^{2} \mathrm{I}^{2}=0.01, \mathrm{df}=\mathrm{I}(\mathrm{P}=0.94) ; \mathrm{I}^{2}=0.0 \%$} \\
\hline \multicolumn{6}{|c|}{ Test for overall effect: $Z=0.53(P=0.59)$} \\
\hline
\end{tabular}

\section{Analysis 4.7. Comparison 4 Oxytocin versus no uterotonics (expectant management only), Outcome 7} Therapeutic uterontonics.

\begin{tabular}{|c|c|c|c|c|c|}
\hline \multicolumn{6}{|c|}{ Comparison: 4 Oxytocin versus no uterotonics (expectant management only) } \\
\hline \multicolumn{6}{|c|}{ Outcome: 7 Therapeutic uterontonics } \\
\hline \multirow[t]{2}{*}{ Study or subgroup } & Oxytocin & Control & Risk Ratio & Weight & Risk Ratio \\
\hline & $n / N$ & $\mathrm{n} / \mathrm{N}$ & M-H,Fixed,95\% Cl & & M-H,Fixed,95\% Cl \\
\hline De Groot 1996 & $14 / 78$ & $26 / 143$ & $\longrightarrow$ & $21.1 \%$ & $0.99[0.55,1.78]$ \\
\hline Nordstrom 1997 & $40 / 513$ & $67 / 487$ & + & $78.9 \%$ & $0.57[0.39,0.82]$ \\
\hline Total $(95 \% \mathrm{CI})$ & 591 & 630 & $\longrightarrow$ & $100.0 \%$ & $0.66[0.48,0.90]$ \\
\hline \multicolumn{6}{|c|}{ Total events: 54 (Oxytocin), 93 (Control) } \\
\hline \multicolumn{6}{|c|}{ Heterogeneity: $\mathrm{Ch}^{2}=2.45, \mathrm{df}=\mathrm{I}(\mathrm{P}=0.12) ; \mathrm{I}^{2}=59 \%$} \\
\hline \multicolumn{6}{|c|}{ Test for overall effect: $Z=2.65(P=0.0080)$} \\
\hline
\end{tabular}


Analysis 4.II. Comparison 4 Oxytocin versus no uterotonics (expectant management only), Outcome I I Manual removal of the placenta.

\begin{tabular}{|c|c|c|c|c|c|}
\hline \multicolumn{6}{|c|}{ Review: Prophylactic oxytocin for the third stage of labour } \\
\hline \multicolumn{6}{|c|}{ Comparison: 4 Oxytocin versus no uterotonics (expectant management only) } \\
\hline \multicolumn{6}{|c|}{ Outcome: II Manual removal of the placenta } \\
\hline \multirow[t]{2}{*}{ Study or subgroup } & Oxytocin & Control & Risk Ratio & \multirow[t]{2}{*}{ Weight } & Risk Ratio \\
\hline & $\mathrm{n} / \mathrm{N}$ & $\mathrm{n} / \mathrm{N}$ & M-H,Fixed,95\% Cl & & M-H,Fixed,95\% Cl \\
\hline De Groot 1996 & |/78 & $0 / 143$ & $\begin{array}{r} \\
\end{array}$ & $3.0 \%$ & $5.47[0.23,132.66]$ \\
\hline Nordstrom 1997 & $18 / 513$ & | $1 / 487$ & + & $97.0 \%$ & $1.55[0.74,3.26]$ \\
\hline Total $(95 \% \mathrm{CI})$ & 591 & 630 & - & $100.0 \%$ & $1.67[0.82,3.41]$ \\
\hline \multicolumn{6}{|c|}{ Total events: 19 (Oxytocin), 11 (Control) } \\
\hline \multicolumn{6}{|c|}{ Heterogeneity: $\mathrm{Chi}^{2}=0.57, \mathrm{df}=\mathrm{I}(\mathrm{P}=0.45) ; \mathrm{I}^{2}=0.0 \%$} \\
\hline \multicolumn{6}{|c|}{ Test for overall effect: $Z=1.41(P=0.16)$} \\
\hline
\end{tabular}

$0.0010 .010 .1 \quad 1 \quad 10 \quad 100 \quad 1000$

Favours Oxytocin Favours Control

Analysis 5.I. Comparison 5 Oxytocin versus no uterotonics (given before placental delivery), Outcome I PPH (clinically estimated blood loss $>$ or $=500 \mathrm{ml}$ ).

Review: Prophylactic oxytocin for the third stage of labour

Comparison: 5 Oxytocin versus no uterotonics (given before placental delivery)

Outcome: I PPH (clinically estimated blood loss $>$ or $=500 \mathrm{ml}$ )

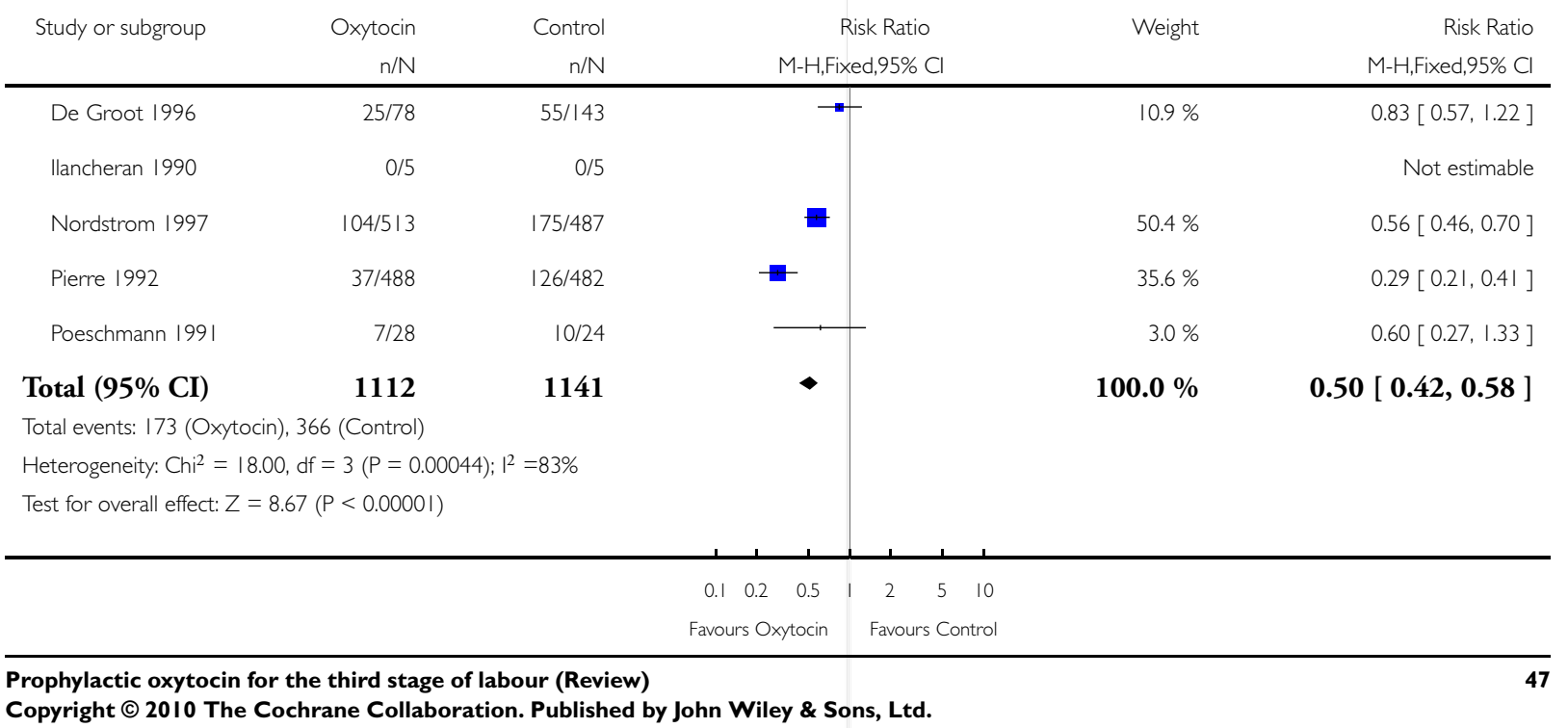


Analysis 5.2. Comparison 5 Oxytocin versus no uterotonics (given before placental delivery), Outcome 2 Severe PPH (clinically estimated blood loss $>$ or $=1000 \mathrm{ml})$.

\begin{tabular}{|c|c|c|c|c|c|}
\hline \multicolumn{6}{|c|}{ Review: Prophylactic oxytocin for the third stage of labour } \\
\hline \multicolumn{6}{|c|}{ Comparison: 5 Oxytocin versus no uterotonics (given before placental delivery) } \\
\hline \multicolumn{6}{|c|}{ Outcome: 2 Severe PPH (clinically estimated blood loss > or = 1000 ml) } \\
\hline \multirow[t]{2}{*}{ Study or subgroup } & Oxytocin & Control & Risk Ratio & Weight & Risk Ratio \\
\hline & $\mathrm{n} / \mathrm{N}$ & $\mathrm{n} / \mathrm{N}$ & \multicolumn{2}{|l|}{ M-H,Fixed,95\% Cl } & M-H,Fixed,95\% Cl \\
\hline De Groot 1996 & $7 / 78$ & $16 / 143$ & $\longrightarrow$ & $14.2 \%$ & $0.80[0.34,1.87]$ \\
\hline Nordstrom 1997 & $32 / 513$ & $43 / 487$ & & $55.3 \%$ & $0.71[0.45,1.10]$ \\
\hline Pierre 1992 & $7 / 488$ & $21 / 482$ & - & $26.5 \%$ & $0.33[0.14,0.77]$ \\
\hline Poeschmann 1991 & $2 / 28$ & $3 / 24$ & & $4.0 \%$ & $0.57[0.10,3.14]$ \\
\hline Total (95\% CI) & 1107 & 1136 & & $100.0 \%$ & $0.61[0.44,0.87]$ \\
\hline \multicolumn{6}{|c|}{ Total events: 48 (Oxytocin), 83 (Control) } \\
\hline \multicolumn{6}{|c|}{ Heterogeneity: $\mathrm{Chi}^{2}=2.86, \mathrm{df}=3(\mathrm{P}=0.4 \mathrm{I}) ; \mathrm{I}^{2}=0.0 \%$} \\
\hline \multicolumn{6}{|c|}{ Test for overall effect: $Z=2.78(P=0.0055)$} \\
\hline
\end{tabular}


Analysis 5.3. Comparison 5 Oxytocin versus no uterotonics (given before placental delivery), Outcome 3 Mean blood loss ( $\mathrm{ml})$.

Review: Prophylactic oxytocin for the third stage of labour

Comparison: 5 Oxytocin versus no uterotonics (given before placental delivery)

Outcome: 3 Mean blood loss (ml)

\begin{tabular}{|c|c|c|c|c|c|c|c|}
\hline \multirow[t]{2}{*}{ Study or subgroup } & \multirow{2}{*}{$\begin{array}{r}\text { Oxytocin } \\
N\end{array}$} & \multicolumn{3}{|c|}{ Control } & \multirow{2}{*}{$\begin{array}{c}\text { Mean } \\
\text { Difference } \\
\text { IV,Fixed,95\% Cl }\end{array}$} & \multirow[t]{2}{*}{ Weight } & \multirow{2}{*}{$\begin{array}{r}\text { Mean } \\
\text { Difference } \\
\text { IV,Fixed,95\% Cl }\end{array}$} \\
\hline & & Mean(SD) & N & Mean(SD) & & & \\
\hline De Groot 1996 & 78 & $499(454)$ & 143 & $520(4 \mid 9)$ & $\rightarrow$ & $12.3 \%$ & $-21.00[-142.93,100.93]$ \\
\hline Nordstrom 1997 & 513 & $409(345)$ & 487 & $527(4 \mid 2)$ & + & $82.2 \%$ & $-118.00[-165.23,-70.77]$ \\
\hline Poeschmann 1991 & 28 & $374(279)$ & 24 & $548(376)$ & $\longrightarrow$ & $5.5 \%$ & $-174.00[-356.5|, 8.5|]$ \\
\hline Total $(95 \% \mathrm{CI})$ & 619 & & 654 & & - & $100.0 \%$ & $-109.12[-151.93,-66.32]$ \\
\hline \multicolumn{8}{|c|}{ Heterogeneity: $\mathrm{Ch}^{2}=2.63, \mathrm{df}=2(\mathrm{P}=0.27) ; \mathrm{I}^{2}=24 \%$} \\
\hline \multicolumn{8}{|c|}{ Test for overall effect: $Z=5.00(P<0.0000 \mathrm{I})$} \\
\hline \multicolumn{8}{|c|}{ Test for subgroup differences: Not applicable } \\
\hline
\end{tabular}

Analysis 5.4. Comparison 5 Oxytocin versus no uterotonics (given before placental delivery), Outcome 4 Maternal haemoglobin concentration $(\mathrm{Hb})<9 \mathrm{gm} /$ deciltre 24 to 48 hours postpartum.

Review: Prophylactic oxytocin for the third stage of labour

Comparison: 5 Oxytocin versus no uterotonics (given before placental delivery)

Outcome: 4 Maternal haemoglobin concentration $(\mathrm{Hb})<9 \mathrm{gm} /$ deciltre 24 to 48 hours postpartum

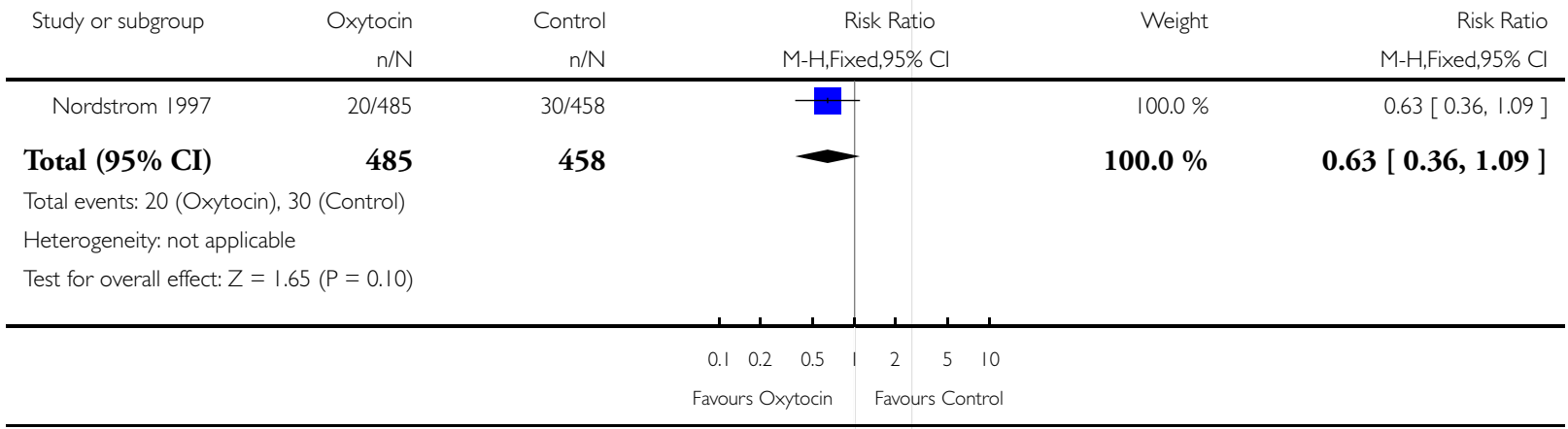

Prophylactic oxytocin for the third stage of labour (Review)

Copyright @ 2010 The Cochrane Collaboration. Published by John Wiley \& Sons, Ltd. 


\section{Analysis 5.5. Comparison 5 Oxytocin versus no uterotonics (given before placental delivery), Outcome 5}

Blood transfusion.

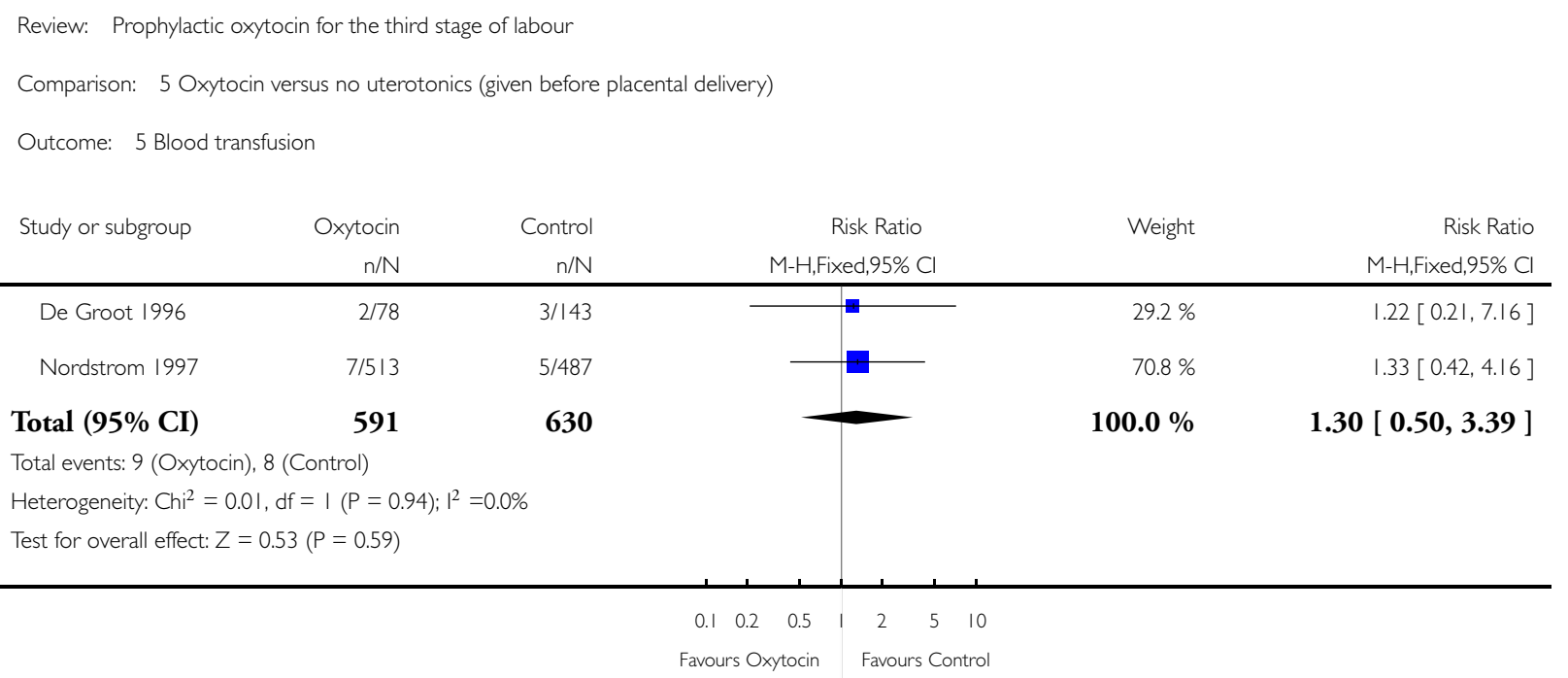


Analysis 5.7. Comparison 5 Oxytocin versus no uterotonics (given before placental delivery), Outcome 7 Therapeutic uterontonics.

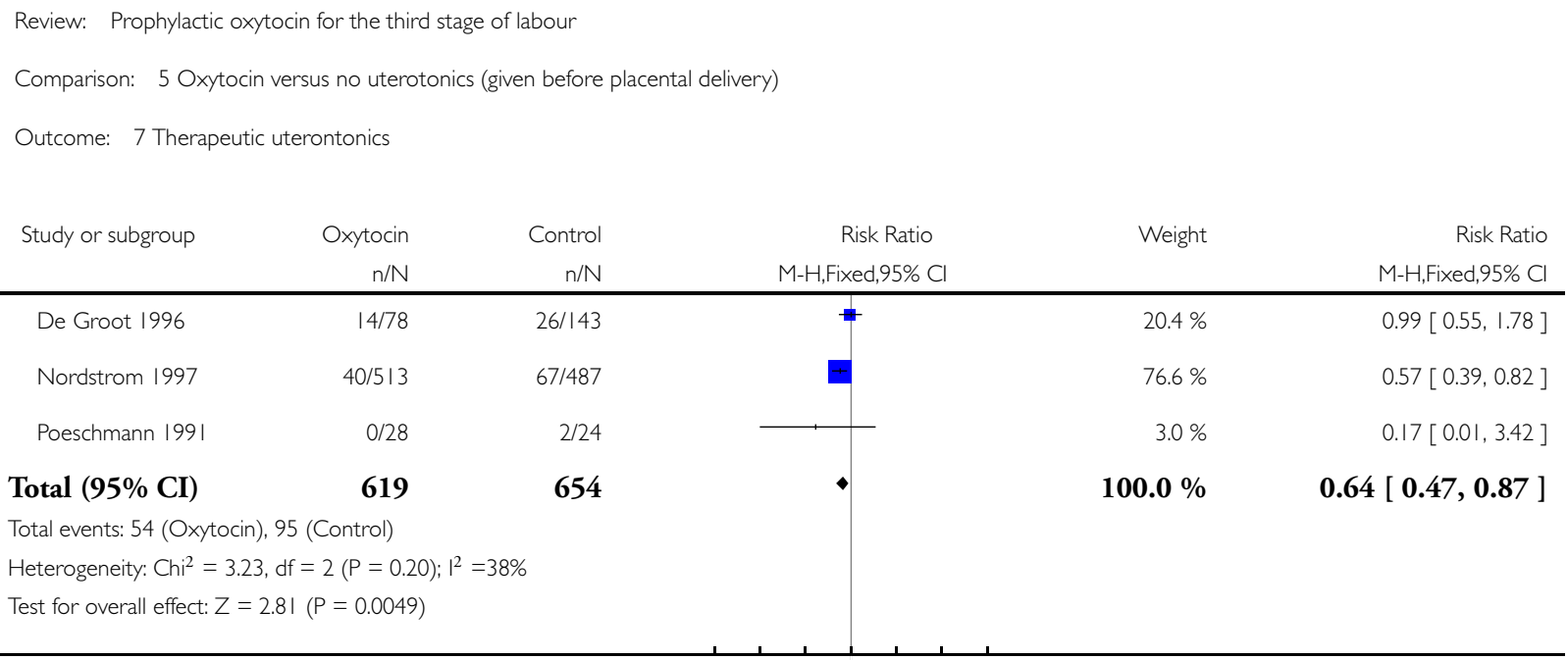

$0.0010 .010 .1 \quad 1 \quad 10 \quad 100 \quad 1000$

Favours Oxytocin Favours Control

Analysis 5.10. Comparison 5 Oxytocin versus no uterotonics (given before placental delivery), Outcome 10 Mean length of third stage (minutes).

Review: Prophylactic oxytocin for the third stage of labour

Comparison: 5 Oxytocin versus no uterotonics (given before placental delivery)

Outcome: 10 Mean length of third stage (minutes)

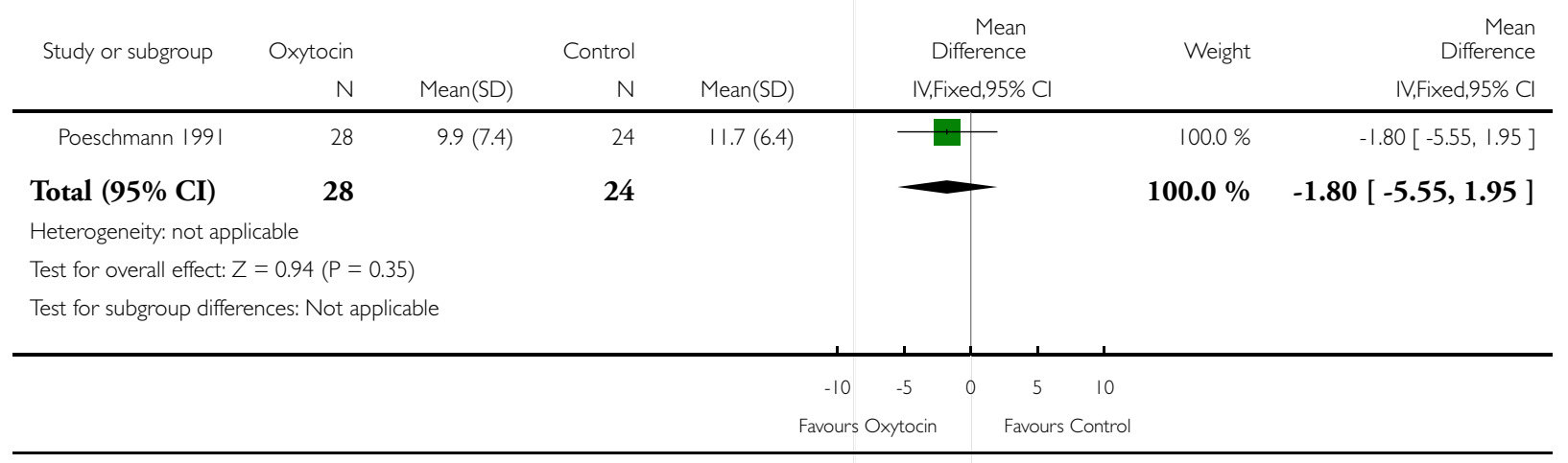

Prophylactic oxytocin for the third stage of labour (Review)

Copyright $\odot 2010$ The Cochrane Collaboration. Published by John Wiley \& Sons, Ltd. 
Analysis 5.I I. Comparison 5 Oxytocin versus no uterotonics (given before placental delivery), Outcome I I Manual removal of the placenta.

\begin{tabular}{|c|c|c|c|c|c|}
\hline \multicolumn{6}{|c|}{ Comparison: 5 Oxytocin versus no uterotonics (given before placental delivery) } \\
\hline Outcome: II Manu & al of the plac & & & & \\
\hline \multirow[t]{2}{*}{ Study or subgroup } & Oxytocin & Control & Risk Ratio & Weight & Risk Ratio \\
\hline & $\mathrm{n} / \mathrm{N}$ & $\mathrm{n} / \mathrm{N}$ & M-H,Fixed, $95 \% \mathrm{Cl}$ & & M-H,Fixed,95\% Cl \\
\hline De Groot 1996 & |/78 & $0 / 143$ & \begin{tabular}{l|l} 
\\
\end{tabular} & $0.8 \%$ & $5.47[0.23,132.66]$ \\
\hline Nordstrom 1997 & $18 / 513$ & | $1 / 487$ & $=$ & $25.7 \%$ & $1.55[0.74,3.26]$ \\
\hline Pierre 1992 & $32 / 488$ & $32 / 482$ & 日 & $73.4 \%$ & $0.99[0.62,1.59]$ \\
\hline Poeschmann 1991 & $0 / 28$ & $0 / 24$ & & & Not estimable \\
\hline Total $(95 \% \mathrm{CI})$ & 1107 & 1136 & - & $100.0 \%$ & $1.17[0.79,1.73]$ \\
\hline \multicolumn{6}{|c|}{ Total events: 51 (Oxytocin), 43 (Control) } \\
\hline \multicolumn{6}{|c|}{ Heterogeneity: $\mathrm{Ch}^{2}=1.95, \mathrm{df}=2(\mathrm{P}=0.38) ; \mathrm{I}^{2}=0.0 \%$} \\
\hline \multicolumn{6}{|c|}{ Test for overall effect: $Z=0.78(P=0.43)$} \\
\hline
\end{tabular}


Analysis 5.15. Comparison 5 Oxytocin versus no uterotonics (given before placental delivery), Outcome 15 Nausea between delivery of the baby and discharge from the labour ward.

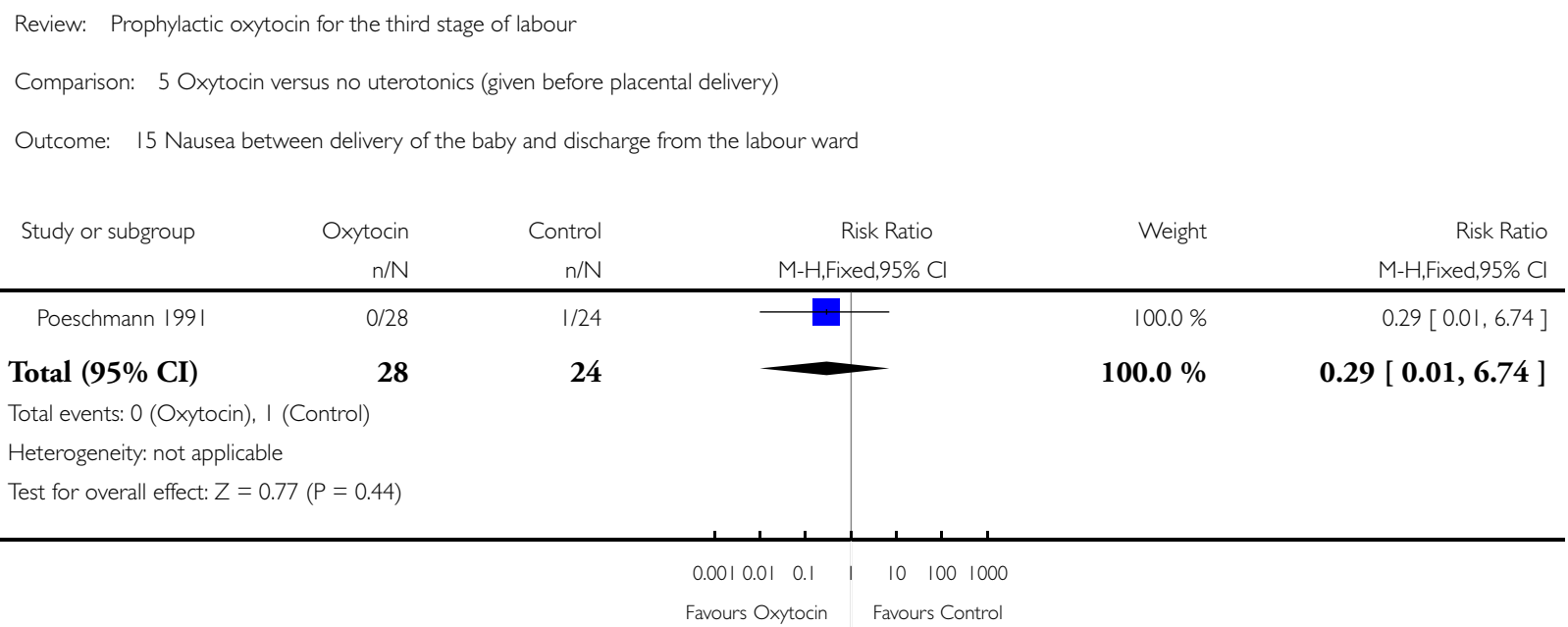

\section{Analysis 6.I. Comparison 6 Oxytocin versus no uterotonics (given after placental delivery), Outcome I} PPH (clinically estimated blood loss $>$ or $=500 \mathrm{ml}$ ).

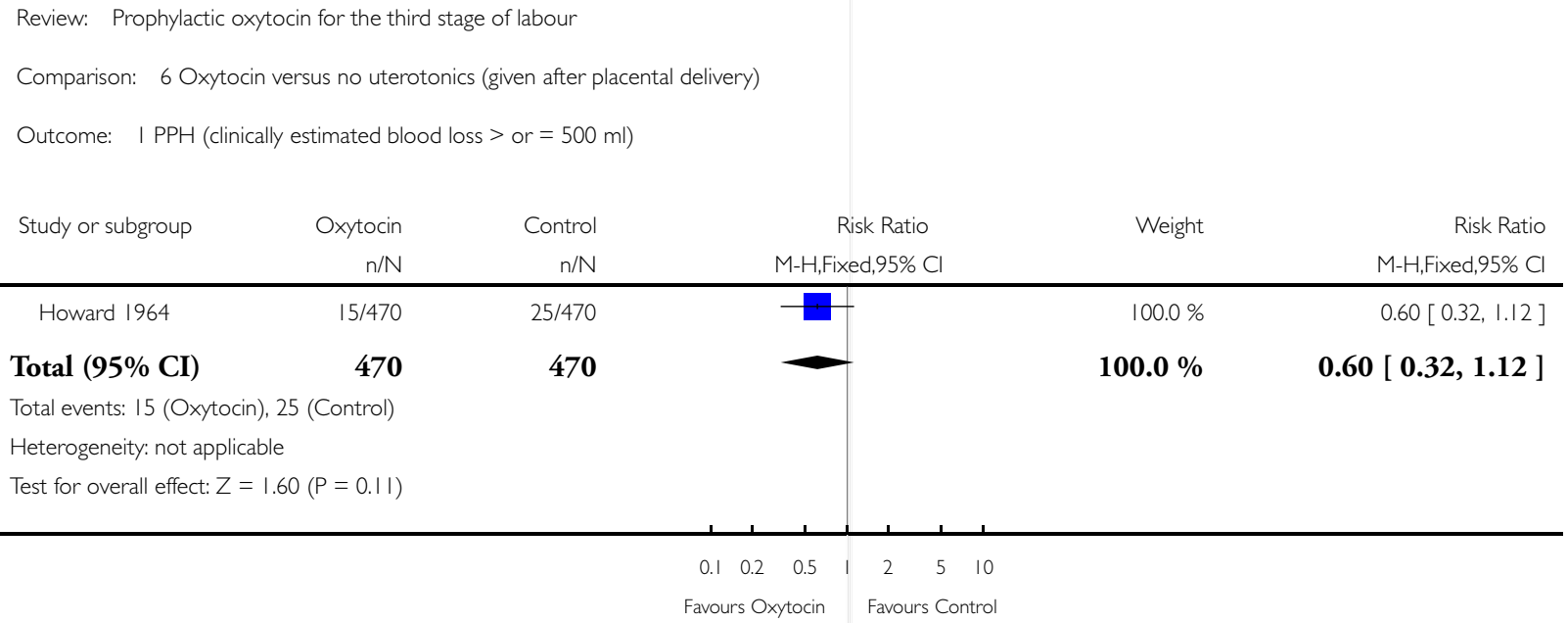


Analysis 6.3. Comparison 6 Oxytocin versus no uterotonics (given after placental delivery), Outcome 3 Mean blood loss (ml).

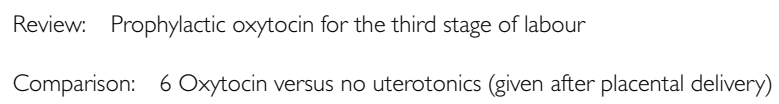

\begin{tabular}{|c|c|c|c|c|c|c|c|}
\hline \multirow[t]{2}{*}{ Study or subgroup } & \multirow{2}{*}{$\begin{array}{r}\text { Oxytocin } \\
N\end{array}$} & \multicolumn{3}{|c|}{ Control } & \multirow{2}{*}{$\begin{array}{c}\text { Mean } \\
\text { Difference } \\
\text { IV,Fixed,95\% Cl }\end{array}$} & \multirow[t]{2}{*}{ Weight } & \multirow{2}{*}{$\begin{array}{r}\text { Mean } \\
\text { Difference } \\
\text { IV,Fixed,95\% Cl }\end{array}$} \\
\hline & & Mean(SD) & $N$ & Mean(SD) & & & \\
\hline Newton 196I & 50 & $345(285)$ & 50 & $333(298)$ & & $100.0 \%$ & $12.00[-102.29,126.29]$ \\
\hline Total (95\% CI) & 50 & & 50 & & & $100.0 \%$ & $12.00[-102.29,126.29]$ \\
\hline \multicolumn{8}{|c|}{ Heterogeneity: not applicable } \\
\hline \multicolumn{8}{|c|}{ Test for overall effect: $Z=0.21(P=0.84)$} \\
\hline \multicolumn{8}{|c|}{ Test for subgroup differences: Not applicable } \\
\hline
\end{tabular}

Analysis 6.7. Comparison 6 Oxytocin versus no uterotonics (given after placental delivery), Outcome 7 Therapeutic uterontonics.

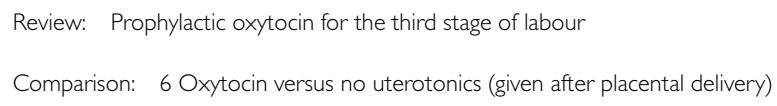

\begin{tabular}{|c|c|c|c|c|c|}
\hline \multirow[t]{2}{*}{ Study or subgroup } & Oxytocin & Control & Risk Ratio & Weight & Risk Ratio \\
\hline & $\mathrm{n} / \mathrm{N}$ & $\mathrm{n} / \mathrm{N}$ & M-H,Fixed,95\% Cl & & M-H,Fixed,95\% Cl \\
\hline Howard 1964 & $21 / 479$ & $58 / 475$ & + & $84.1 \%$ & $0.36[0.22,0.58]$ \\
\hline Newton 1961 & $1 / 50$ & $11 / 50$ & $\longrightarrow$ & $15.9 \%$ & $0.09[0.01,0.68]$ \\
\hline Total $(95 \% \mathrm{CI})$ & 529 & 525 & $\bullet$ & $100.0 \%$ & $0.32[0.20,0.50]$ \\
\hline \multicolumn{6}{|c|}{ Total events: 22 (Oxytocin), 69 (Control) } \\
\hline \multicolumn{6}{|c|}{ Heterogeneity: $\mathrm{Chi}^{2}=1.74, \mathrm{df}=\mathrm{I}(\mathrm{P}=0.19) ; \mathrm{I}^{2}=43 \%$} \\
\hline \multicolumn{6}{|c|}{ Test for overall effect: $Z=4.85(P<0.0000 \mathrm{I})$} \\
\hline
\end{tabular}




\section{Analysis 7.I. Comparison 7 Oxytocin versus ergot alkaloids (all trials), Outcome I PPH (clinically}

estimated blood loss $>$ or $=500 \mathrm{ml}$ ).

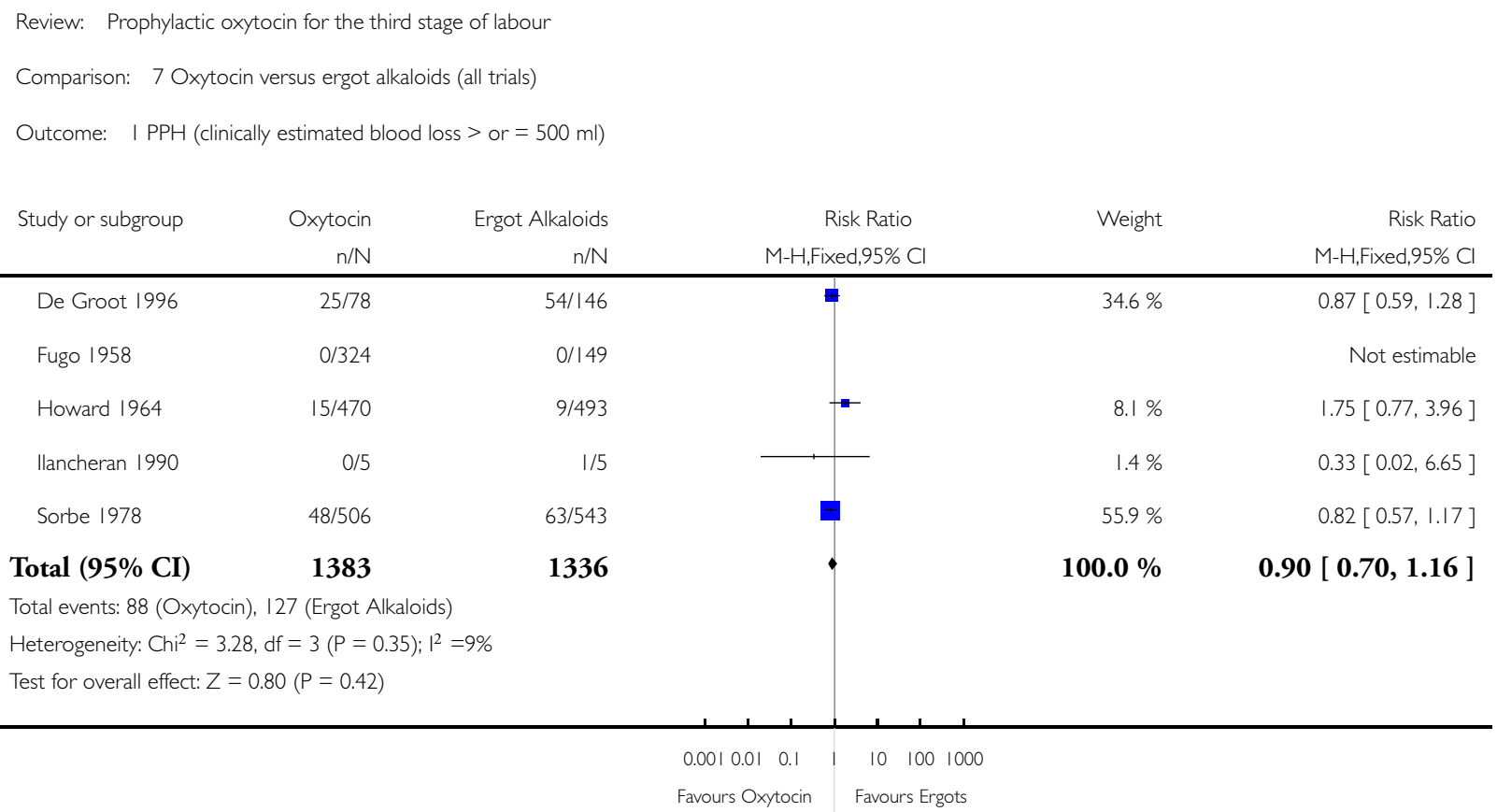


Analysis 7.2. Comparison 7 Oxytocin versus ergot alkaloids (all trials), Outcome 2 Severe PPH (clinically estimated blood loss $>$ or $=1000 \mathrm{ml})$.

\begin{tabular}{|c|c|c|c|c|c|}
\hline \multicolumn{6}{|c|}{ Comparison: 7 Oxytocin versus ergot alkaloids (all trials) } \\
\hline \multicolumn{6}{|c|}{ Outcome: 2 Severe PPH (clinically estimated blood loss > or $=1000 \mathrm{ml}$ ) } \\
\hline \multirow[t]{2}{*}{ Study or subgroup } & Oxytocin & Ergot Alkaloids & Risk Ratio & Weight & Risk Ratio \\
\hline & $\mathrm{n} / \mathrm{N}$ & $\mathrm{n} / \mathrm{N}$ & M-H,Fixed,95\% Cl & & M-H,Fixed,95\% Cl \\
\hline De Groot 1996 & $7 / 78$ & $12 / 146$ & $\longrightarrow$ & $36.6 \%$ & $1.09[0.45,2.66]$ \\
\hline Fugo 1958 & $0 / 324$ & $0 / 149$ & & & Not estimable \\
\hline Sorbe 1978 & $13 / 506$ & $15 / 543$ & + & $63.4 \%$ & $0.93[0.45,1.94]$ \\
\hline Total $(95 \% \mathrm{CI})$ & 908 & 838 & - & $100.0 \%$ & $0.99[0.56,1.74]$ \\
\hline \multicolumn{6}{|c|}{ Total events: 20 (Oxytocin), 27 (Ergot Alkaloids) } \\
\hline \multicolumn{6}{|c|}{ Heterogeneity: $\mathrm{Chi}^{2}=0.07, \mathrm{df}=\mathrm{I}(\mathrm{P}=0.78) ; \mathrm{I}^{2}=0.0 \%$} \\
\hline \multicolumn{6}{|c|}{ Test for overall effect: $Z=0.04(P=0.97)$} \\
\hline
\end{tabular}

Analysis 7.3. Comparison 7 Oxytocin versus ergot alkaloids (all trials), Outcome 3 Mean blood loss (ml).

Review: Prophylactic oxytocin for the third stage of labour

Comparison: 7 Oxytocin versus ergot alkaloids (all trials)

Outcome: 3 Mean blood loss $(\mathrm{ml})$

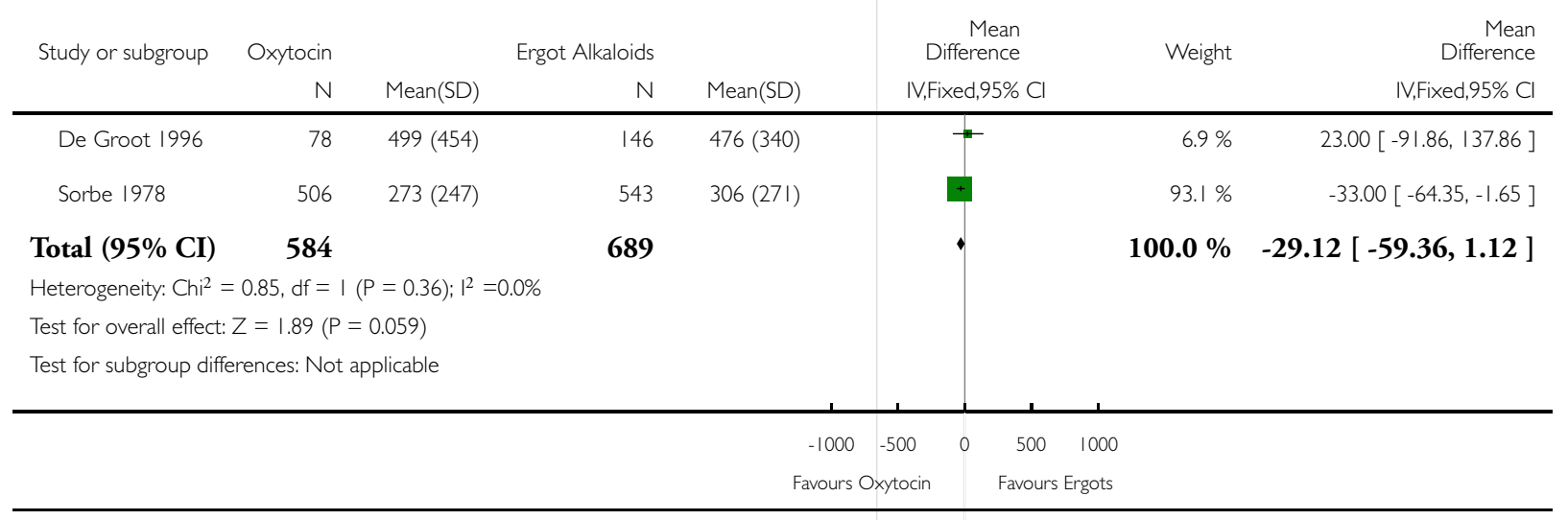

Prophylactic oxytocin for the third stage of labour (Review)

Copyright $\odot 2010$ The Cochrane Collaboration. Published by John Wiley \& Sons, Ltd. 


\section{Analysis 7.5. Comparison 7 Oxytocin versus ergot alkaloids (all trials), Outcome 5 Blood transfusion.}

Review: Prophylactic oxytocin for the third stage of labour

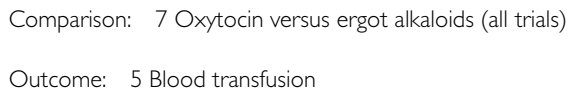

\begin{tabular}{|c|c|c|c|c|c|}
\hline \multirow[t]{2}{*}{ Study or subgroup } & Oxytocin & Ergot Alkaloids & Risk Ratio & Weight & Risk Ratio \\
\hline & $\mathrm{n} / \mathrm{N}$ & $\mathrm{n} / \mathrm{N}$ & M-H,Fixed,95\% Cl & & M-H,Fixed,95\% Cl \\
\hline De Groot 1996 & $2 / 78$ & $1 / 146$ & +1 & $100.0 \%$ & $3.74[0.34,40.64]$ \\
\hline Total (95\% CI) & 78 & 146 & & $100.0 \%$ & $3.74[0.34,40.64]$ \\
\hline \multicolumn{6}{|c|}{ Total events: 2 (Oxytocin), I (Ergot Alkaloids) } \\
\hline \multicolumn{6}{|c|}{ Heterogeneity: not applicable } \\
\hline \multicolumn{6}{|c|}{ Test for overall effect: $Z=1.08(P=0.28)$} \\
\hline
\end{tabular}




\section{Analysis 7.7. Comparison 7 Oxytocin versus ergot alkaloids (all trials), Outcome 7 Therapeutic}

uterontonics.

Review: Prophylactic oxytocin for the third stage of labour

Comparison: 7 Oxytocin versus ergot alkaloids (all trials)

Outcome: 7 Therapeutic uterontonics

\begin{tabular}{|c|c|c|c|c|c|}
\hline \multirow[t]{2}{*}{ Study or subgroup } & Oxytocin & Ergot Alkaloids & Risk Ratio & Weight & Risk Ratio \\
\hline & $\mathrm{n} / \mathrm{N}$ & $\mathrm{n} / \mathrm{N}$ & M-H,Fixed,95\% Cl & & M-H,Fixed,95\% Cl \\
\hline De Groot 1996 & $14 / 78$ & $21 / 146$ & -6 & $37.5 \%$ & $1.25[0.67,2.31]$ \\
\hline Howard 1964 & $21 / 479$ & $25 / 505$ & 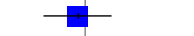 & $62.5 \%$ & $0.89[0.50,1.56]$ \\
\hline
\end{tabular}

Total (95\% CI)

557

${ }^{651}$

$100.0 \%$

$1.02[0.67,1.55]$

Total events: 35 (Oxytocin), 46 (Ergot Alkaloids)

Heterogeneity: $\mathrm{Chi}^{2}=0.65, \mathrm{df}=\mathrm{I}(\mathrm{P}=0.42) ; \mathrm{I}^{2}=0.0 \%$

Test for overall effect: $Z=0.10(P=0.92)$

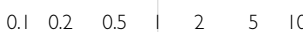

Favours Oxytocin Favours Ergots

Analysis 7.8. Comparison 7 Oxytocin versus ergot alkaloids (all trials), Outcome 8 Third stage $>20$ minutes.

Review: Prophylactic oxytocin for the third stage of labour

Comparison: 7 Oxytocin versus ergot alkaloids (all trials)

Outcome: 8 Third stage $>20$ minutes

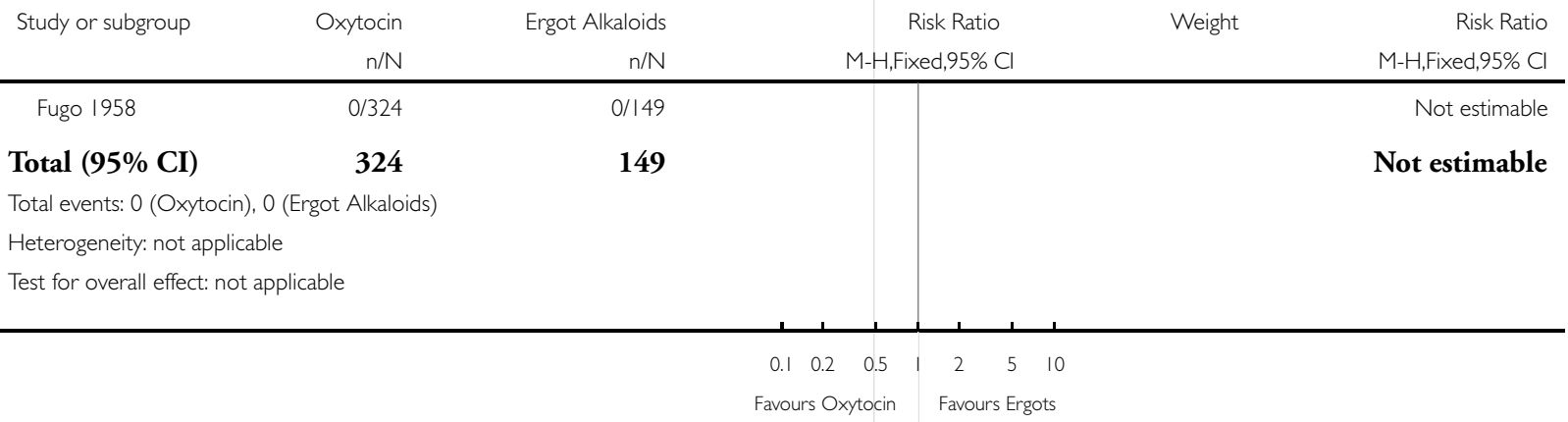


Analysis 7.9. Comparison 7 Oxytocin versus ergot alkaloids (all trials), Outcome 9 Third stage $>40$ minutes.

Review: Prophylactic oxytocin for the third stage of labour

Comparison: 7 Oxytocin versus ergot alkaloids (all trials)

Outcome: 9 Third stage $>40$ minutes

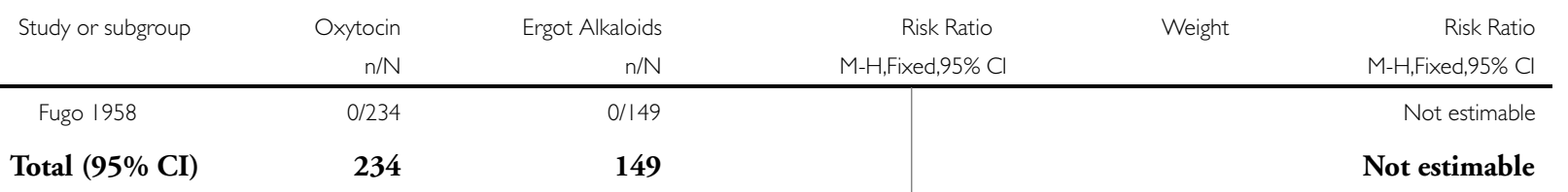

Total events: 0 (Oxytocin), 0 (Ergot Alkaloids)

Heterogeneity: not applicable

Test for overall effect: not applicable

$\begin{array}{lllllll}0.1 & 0.2 & 0.5 & \mid & 2 & 5 & 10\end{array}$

Favours Oxytocin Favours Ergots

Analysis 7.10. Comparison 7 Oxytocin versus ergot alkaloids (all trials), Outcome 10 Mean length of third stage (minutes).

Review: Prophylactic oxytocin for the third stage of labour

Comparison: 7 Oxytocin versus ergot alkaloids (all trials)

Outcome: 10 Mean length of third stage (minutes)

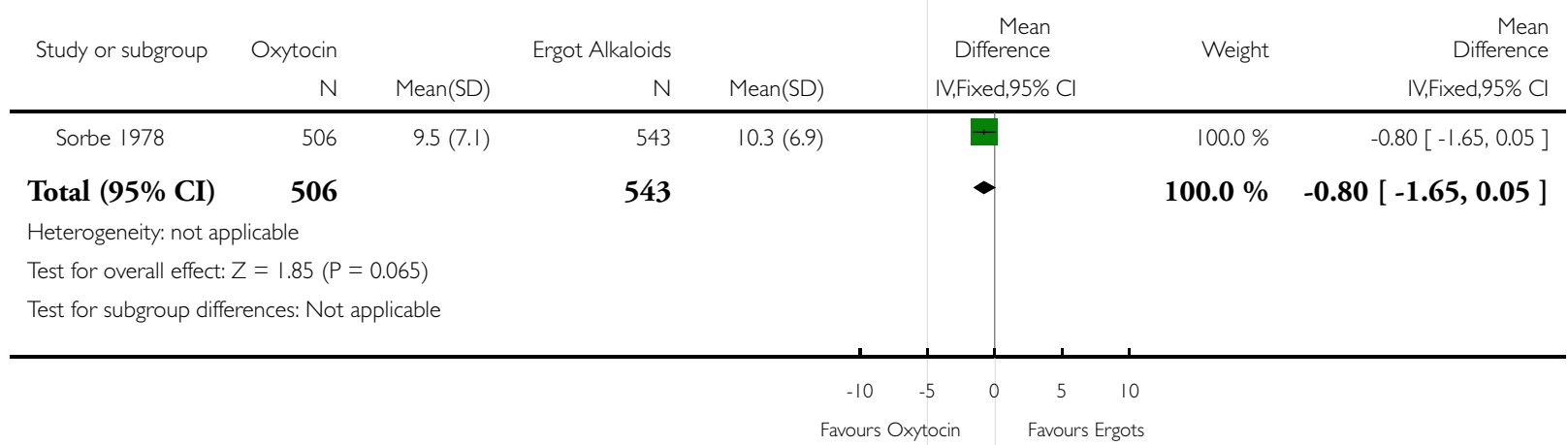




\section{Analysis 7.II. Comparison 7 Oxytocin versus ergot alkaloids (all trials), Outcome II Manual removal of the}

placenta.

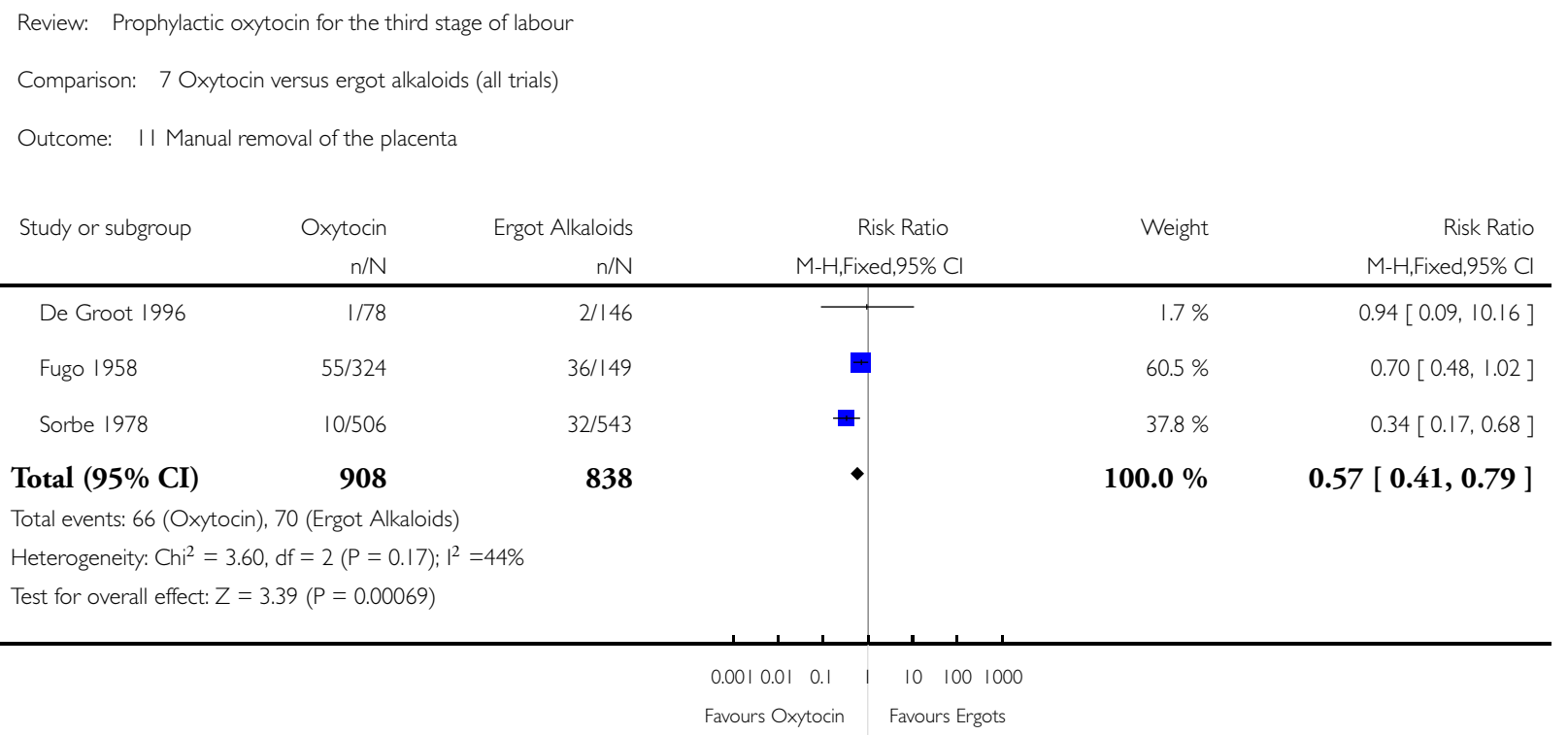

\section{Analysis 7.13. Comparison 7 Oxytocin versus ergot alkaloids (all trials), Outcome I 3 Diastolic blood} pressure > $100 \mathrm{~mm} \mathrm{Hg}$ between delivery of the baby and discharge from the labour ward.

Review: Prophylactic oxytocin for the third stage of labour

Comparison: 7 Oxytocin versus ergot alkaloids (all trials)

Outcome: 13 Diastolic blood pressure $>100 \mathrm{~mm} \mathrm{Hg}$ between delivery of the baby and discharge from the labour ward

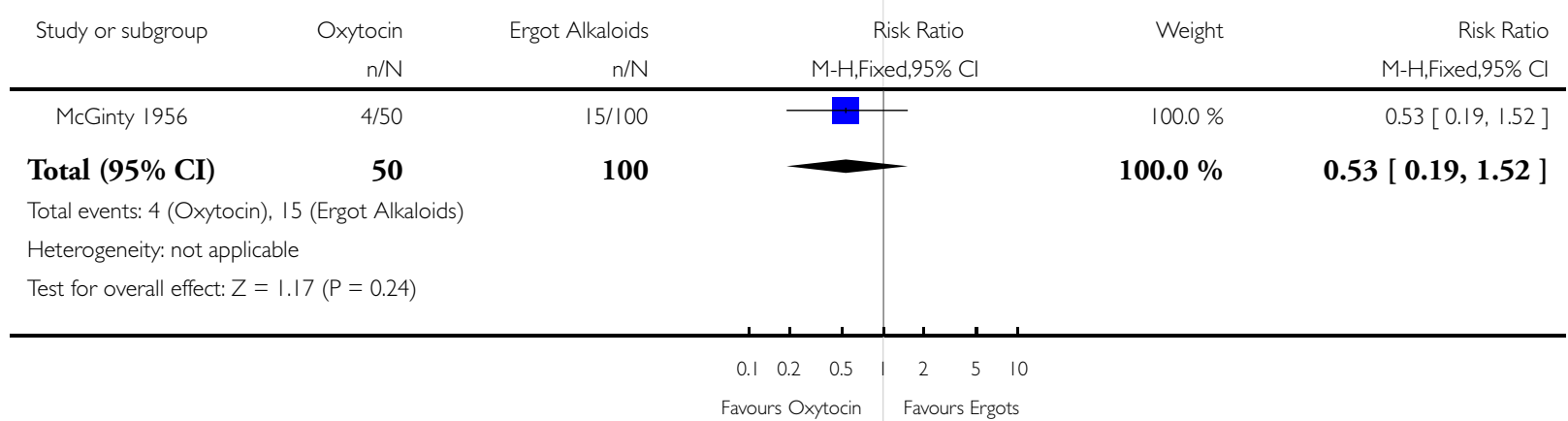


Analysis 8.I. Comparison 8 Oxytocin versus ergot alkaloids (randomised trials only), Outcome I PPH (clinically estimated blood loss $>$ or $=500 \mathrm{ml}$ ).

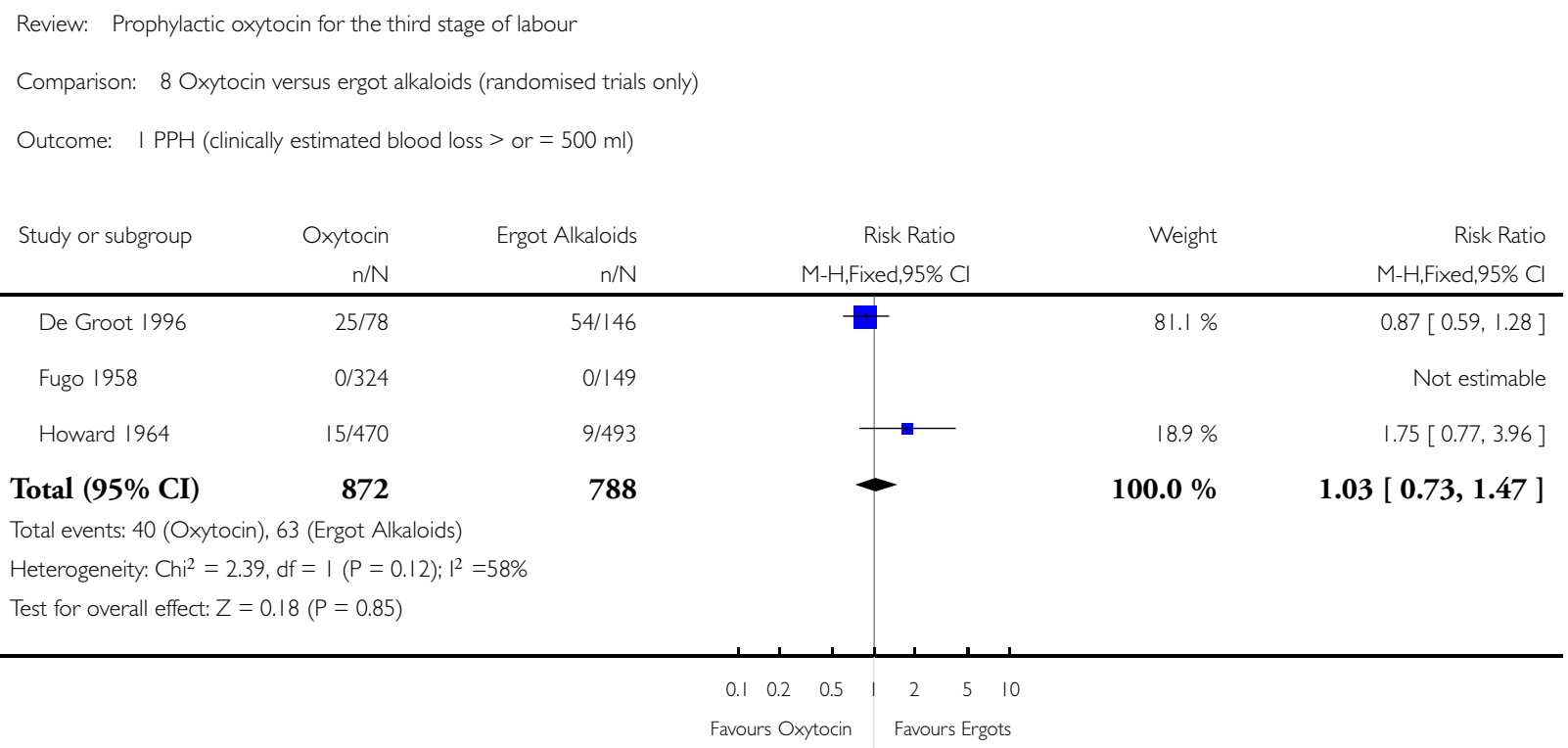

\section{Analysis 8.2. Comparison 8 Oxytocin versus ergot alkaloids (randomised trials only), Outcome 2 Severe} PPH (clinically estimated blood loss $>$ or $=1000 \mathrm{ml}$ ).

Review: Prophylactic oxytocin for the third stage of labour

Comparison: 8 Oxytocin versus ergot alkaloids (randomised trials only)

Outcome: 2 Severe PPH (clinically estimated blood loss $>$ or $=1000 \mathrm{ml}$ )

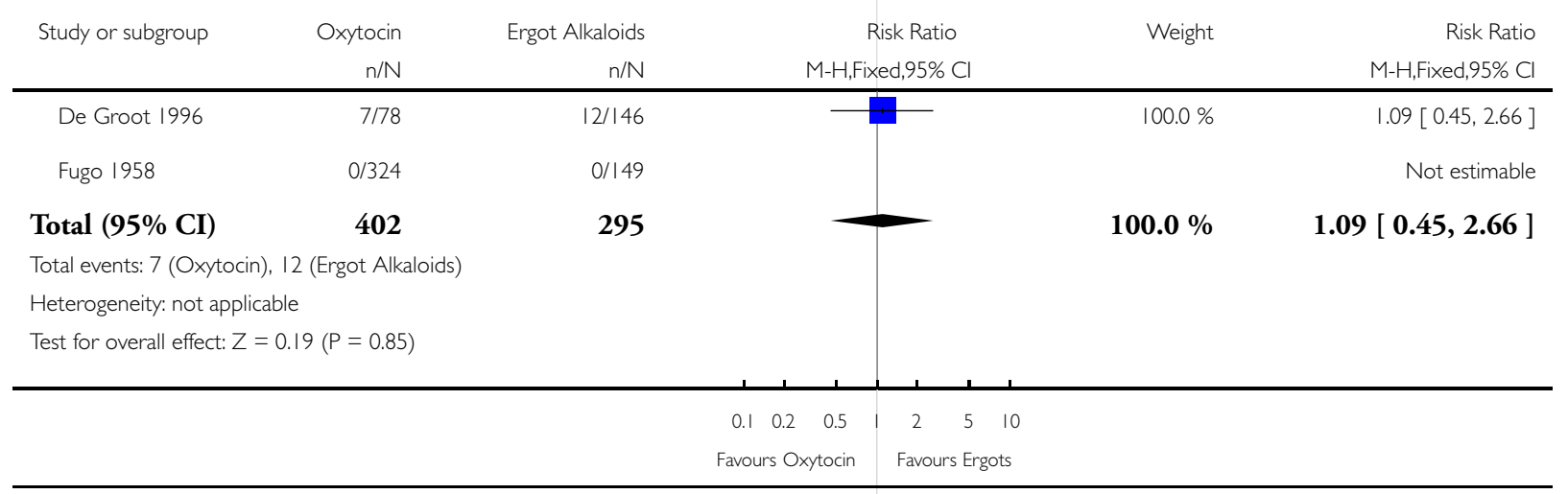

Prophylactic oxytocin for the third stage of labour (Review) 


\section{Analysis 8.3. Comparison 8 Oxytocin versus ergot alkaloids (randomised trials only), Outcome 3 Mean}

blood loss $(\mathrm{ml})$.

Review: Prophylactic oxytocin for the third stage of labour

Comparison: 8 Oxytocin versus ergot alkaloids (randomised trials only)

Outcome: 3 Mean blood loss $(\mathrm{ml})$

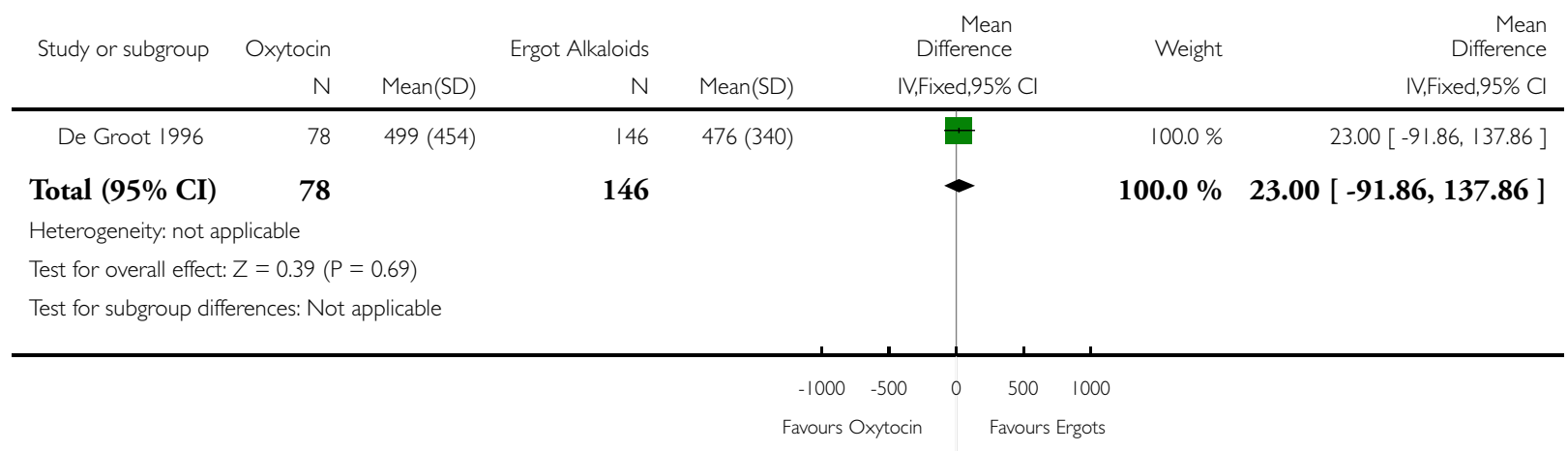


Analysis 8.5. Comparison 8 Oxytocin versus ergot alkaloids (randomised trials only), Outcome 5 Blood transfusion.

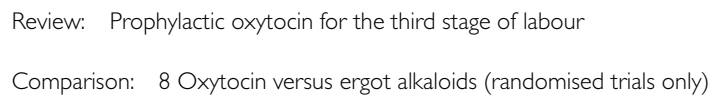

\begin{tabular}{|c|c|c|c|c|c|}
\hline \multirow[t]{2}{*}{ Study or subgroup } & Oxytocin & Ergot Alkaloids & Risk Ratio & Weight & Risk Ratio \\
\hline & $n / N$ & $\mathrm{n} / \mathrm{N}$ & M-H,Fixed,95\% Cl & & M-H,Fixed,95\% Cl \\
\hline De Groot 1996 & $2 / 78$ & $1 / 146$ & 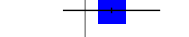 & $100.0 \%$ & $3.74[0.34,40.64]$ \\
\hline Total (95\% CI) & 78 & 146 & & $100.0 \%$ & {$[0.34,40.64]$} \\
\hline
\end{tabular}

Total events: 2 (Oxytocin), I (Ergot Alkaloids)

Heterogeneity: not applicable

Test for overall effect: $Z=1.08(P=0.28)$

$0.0010 .010 .1 \quad 1 \quad 10 \quad 100 \quad 1000$

Favours Oxytocin Favours Ergots

Analysis 8.7. Comparison 8 Oxytocin versus ergot alkaloids (randomised trials only), Outcome 7

Therapeutic uterontonics.

Review: Prophylactic oxytocin for the third stage of labour

Comparison: 8 Oxytocin versus ergot alkaloids (randomised trials only)

Outcome: 7 Therapeutic uterontonics

\begin{tabular}{|c|c|c|c|c|c|}
\hline \multirow[t]{2}{*}{ Study or subgroup } & Oxytocin & Ergot Alkaloids & Risk Ratio & \multirow[t]{2}{*}{ Weight } & Risk Ratio \\
\hline & $\mathrm{n} / \mathrm{N}$ & $\mathrm{n} / \mathrm{N}$ & M-H,Fixed,95\% Cl & & M-H,Fixed,95\% Cl \\
\hline De Groot 1996 & $14 / 78$ & $21 / 146$ & -1 & $37.5 \%$ & $1.25[0.67,2.31]$ \\
\hline Howard 1964 & $21 / 479$ & $25 / 505$ & & $62.5 \%$ & $0.89[0.50,1.56]$ \\
\hline Total (95\% CI) & 557 & 651 & & $100.0 \%$ & $1.02[0.67,1.55]$ \\
\hline \multicolumn{6}{|c|}{ Total events: 35 (Oxytocin), 46 (Ergot Alkaloids) } \\
\hline \multicolumn{6}{|c|}{ Heterogeneity: Chi $^{2}=0.65, d f=|(P=0.42) ;|^{2}=0.0 \%$} \\
\hline \multicolumn{6}{|c|}{ Test for overall effect: $Z=0.10(P=0.92)$} \\
\hline
\end{tabular}


Analysis 8.8. Comparison 8 Oxytocin versus ergot alkaloids (randomised trials only), Outcome 8 Third stage $>20$ minutes.

\begin{tabular}{|c|c|c|c|c|c|}
\hline \multicolumn{6}{|c|}{ Comparison: 8 Oxytocin versus ergot alkaloids (randomised trials only) } \\
\hline \multicolumn{6}{|c|}{ Outcome: 8 Third stage $>20$ minutes } \\
\hline \multirow[t]{2}{*}{ Study or subgroup } & Oxytocin & Ergot Alkaloids & Risk Ratio & \multirow[t]{2}{*}{ Weight } & Risk Ratio \\
\hline & $\mathrm{n} / \mathrm{N}$ & $\mathrm{n} / \mathrm{N}$ & M-H,Fixed,95\% Cl & & M-H,Fixed,95\% Cl \\
\hline Fugo 1958 & 0/324 & $0 / 149$ & & & Not estimable \\
\hline Total $(95 \% \mathrm{CI})$ & 324 & 149 & & & Not estimable \\
\hline \multicolumn{6}{|c|}{ Total events: 0 (Oxytocin), 0 (Ergot Alkaloids) } \\
\hline \multicolumn{6}{|c|}{ Heterogeneity: not applicable } \\
\hline \multicolumn{6}{|c|}{ Test for overall effect: not applicable } \\
\hline
\end{tabular}

\section{Analysis 8.9. Comparison 8 Oxytocin versus ergot alkaloids (randomised trials only), Outcome 9 Third stage $>\mathbf{4 0}$ minutes.}

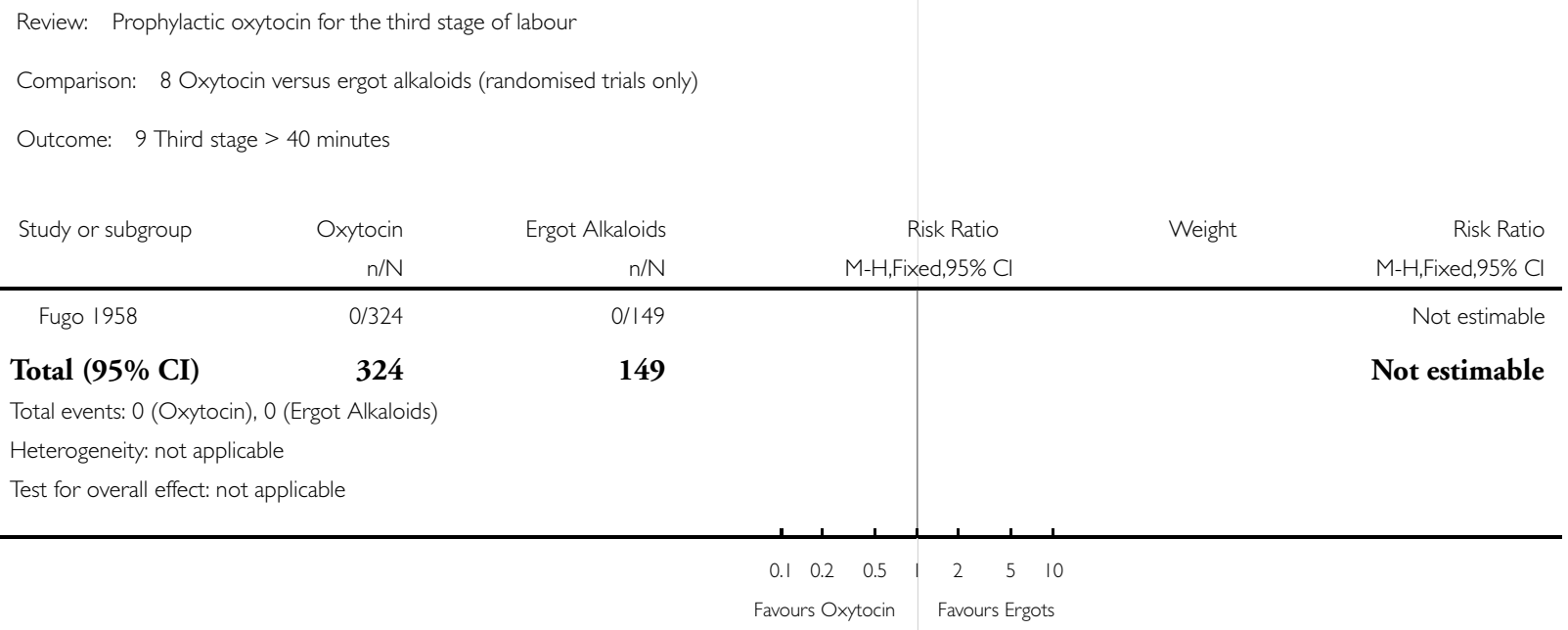


Analysis 8. I I. Comparison 8 Oxytocin versus ergot alkaloids (randomised trials only), Outcome II Manual removal of the placenta.

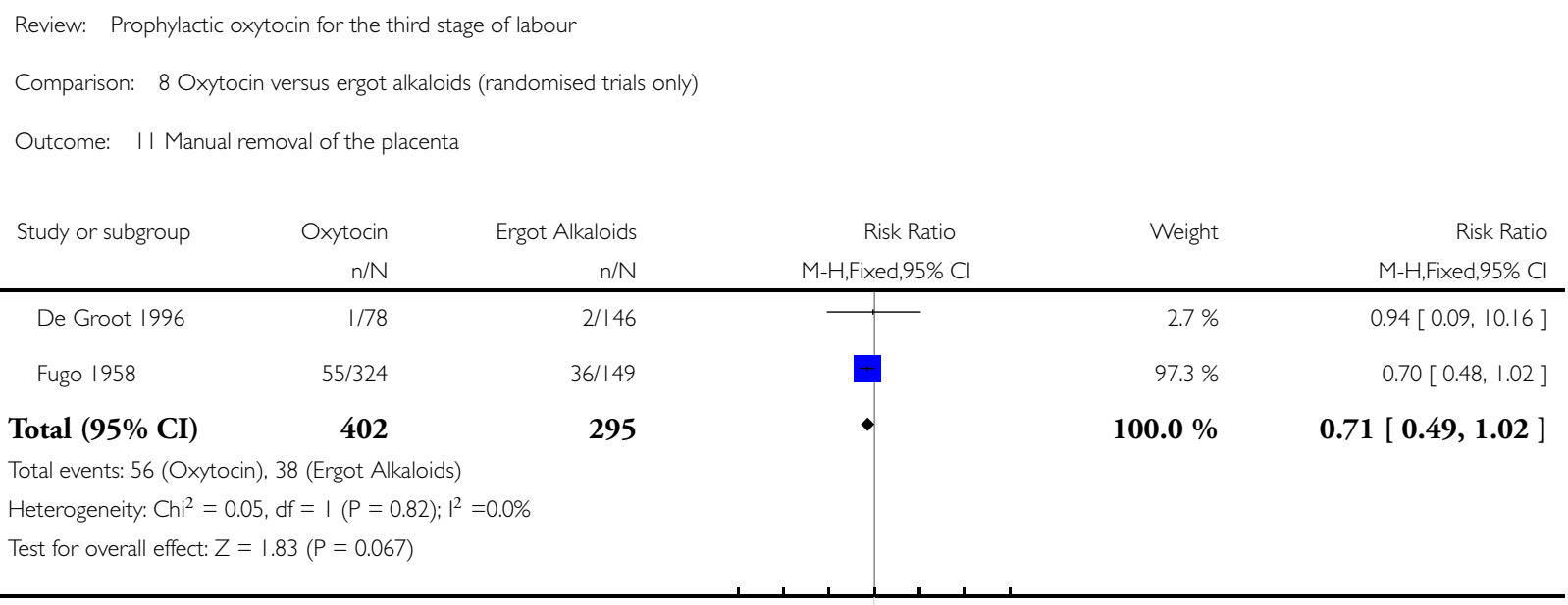

$0.0010 .010 .1 \quad 1 \quad 10 \quad 100 \quad 1000$

Favours Oxytocin Favours Ergots

\section{Analysis 10.I. Comparison I0 Oxytocin versus ergot alkaloids (expectant management only), Outcome I} PPH (clinically estimated blood loss $>$ or $=500 \mathrm{ml}$ ).

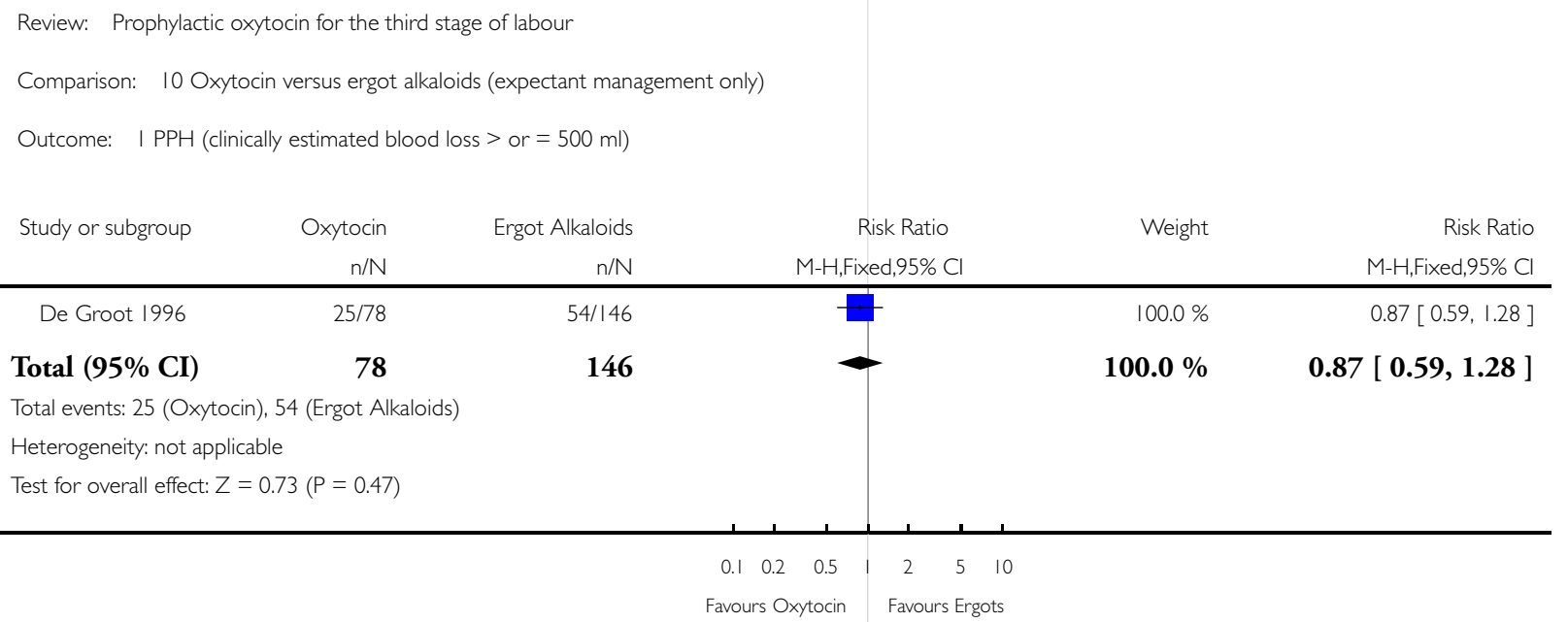


Analysis 10.2. Comparison 10 Oxytocin versus ergot alkaloids (expectant management only), Outcome 2 Severe PPH (clinically estimated blood loss $>$ or $=1000 \mathrm{ml}$ ).

\begin{tabular}{|c|c|c|c|c|c|}
\hline \multicolumn{6}{|c|}{ Comparison: 10 Oxytocin versus ergot alkaloids (expectant management only) } \\
\hline \multicolumn{6}{|c|}{ Outcome: 2 Severe PPH (clinically estimated blood loss $>$ or $=1000 \mathrm{ml}$ ) } \\
\hline \multirow[t]{2}{*}{ Study or subgroup } & Oxytocin & Ergot Alkaloids & Risk Ratio & Weight & Risk Ratio \\
\hline & $\mathrm{n} / \mathrm{N}$ & $\mathrm{n} / \mathrm{N}$ & M-H,Fixed,95\% Cl & & M-H,Fixed,95\% Cl \\
\hline De Groot 1996 & $7 / 78$ & $12 / 146$ & + & $100.0 \%$ & $1.09[0.45,2.66]$ \\
\hline Total $(95 \% \mathrm{CI})$ & 78 & 146 & & $100.0 \%$ & $1.09[0.45,2.66]$ \\
\hline \multicolumn{6}{|c|}{ Total events: 7 (Oxytocin), 12 (Ergot Alkaloids) } \\
\hline \multicolumn{6}{|c|}{ Heterogeneity: not applicable } \\
\hline \multicolumn{6}{|c|}{ Test for overall effect: $Z=0.19(P=0.85)$} \\
\hline
\end{tabular}

Analysis 10.3. Comparison 10 Oxytocin versus ergot alkaloids (expectant management only), Outcome 3 Mean blood loss (ml).

Review: Prophylactic oxytocin for the third stage of labour

Comparison: 10 Oxytocin versus ergot alkaloids (expectant management only)

Outcome: 3 Mean blood loss $(\mathrm{ml})$

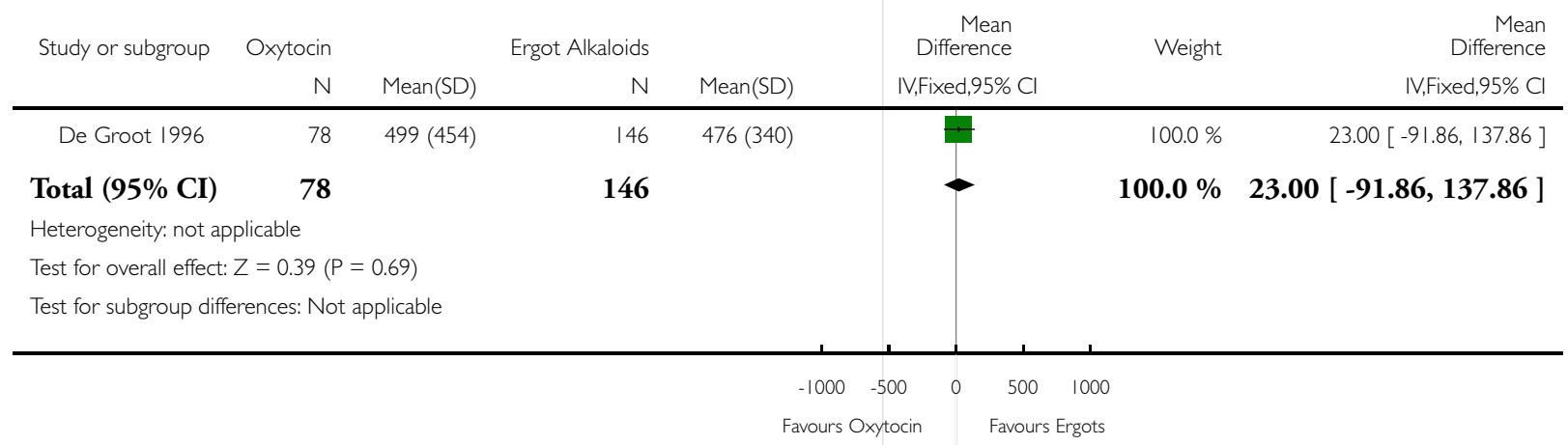


Analysis 10.5. Comparison 10 Oxytocin versus ergot alkaloids (expectant management only), Outcome 5 Blood transfusion.

Review: Prophylactic oxytocin for the third stage of labour

Comparison: 10 Oxytocin versus ergot alkaloids (expectant management only)

Outcome: 5 Blood transfusion

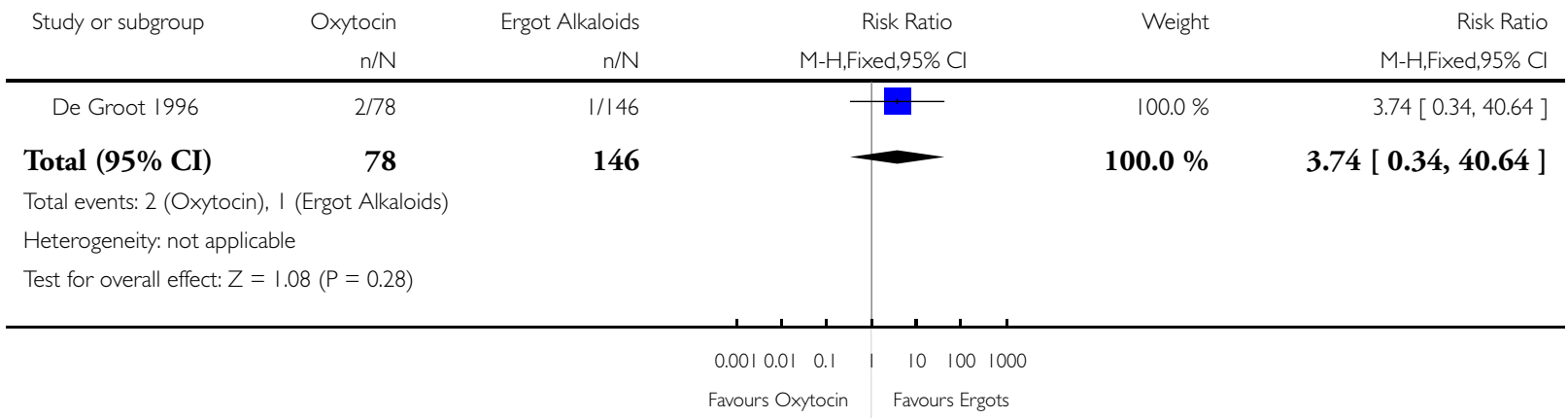

\section{Analysis 10.7. Comparison 10 Oxytocin versus ergot alkaloids (expectant management only), Outcome 7} Therapeutic uterontonics.

Review: Prophylactic oxytocin for the third stage of labour

Comparison: 10 Oxytocin versus ergot alkaloids (expectant management only)

Outcome: 7 Therapeutic uterontonics

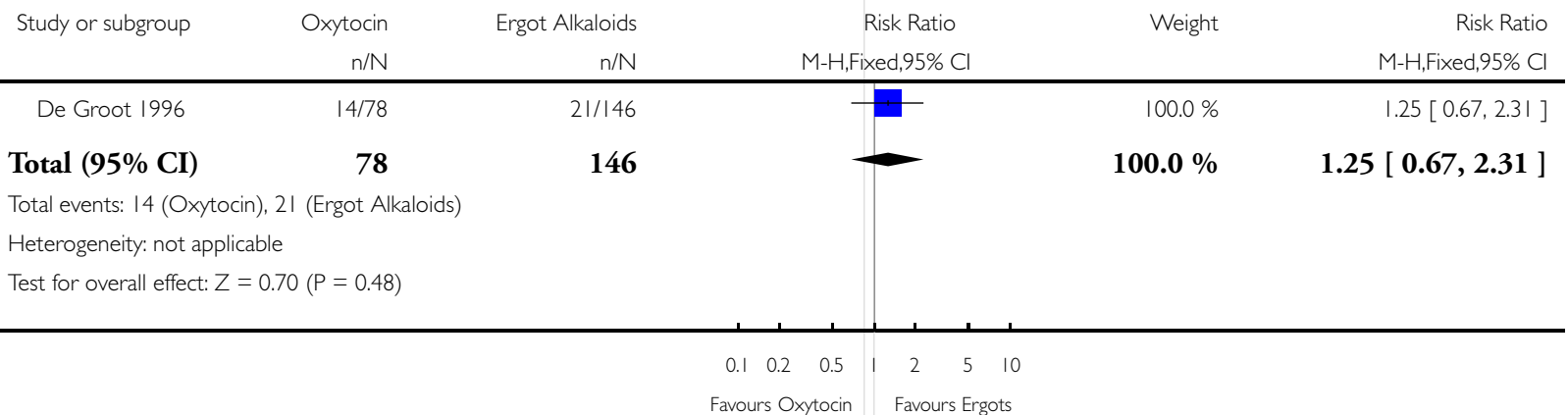




\section{Analysis 10.I I. Comparison 10 Oxytocin versus ergot alkaloids (expectant management only), Outcome I I}

Manual removal of the placenta.

\begin{tabular}{|c|c|c|c|c|c|}
\hline \multicolumn{6}{|c|}{ Comparison: 10 Oxytocin versus ergot alkaloids (expectant management only) } \\
\hline \multicolumn{6}{|c|}{ Outcome: II Manual removal of the placenta } \\
\hline \multirow[t]{2}{*}{ Study or subgroup } & Oxytocin & Ergot Alkaloids & Risk Ratio & Weight & Risk Ratio \\
\hline & $\mathrm{n} / \mathrm{N}$ & $\mathrm{n} / \mathrm{N}$ & M-H,Fixed,95\% Cl & & M-H,Fixed,95\% Cl \\
\hline De Groot 1996 & $1 / 78$ & $2 / 146$ & +2 & $100.0 \%$ & $0.94[0.09,10.16]$ \\
\hline Total $(95 \% \mathrm{CI})$ & 78 & 146 & & $100.0 \%$ & $0.94[0.09,10.16]$ \\
\hline \multicolumn{6}{|c|}{ Total events: I (Oxytocin), 2 (Ergot Alkaloids) } \\
\hline \multicolumn{6}{|c|}{ Heterogeneity: not applicable } \\
\hline \multicolumn{6}{|c|}{ Test for overall effect: $Z=0.05(P=0.96)$} \\
\hline
\end{tabular}

\section{Analysis I I.I. Comparison I I Oxytocin versus ergot alkaloids (given before placental delivery), Outcome I} PPH (clinically estimated blood loss $>$ or $=500 \mathrm{ml}$ ).

Review: Prophylactic oxytocin for the third stage of labour

Comparison: II Oxytocin versus ergot alkaloids (given before placental delivery)

Outcome: I PPH (clinically estimated blood loss $>$ or $=500 \mathrm{ml})$

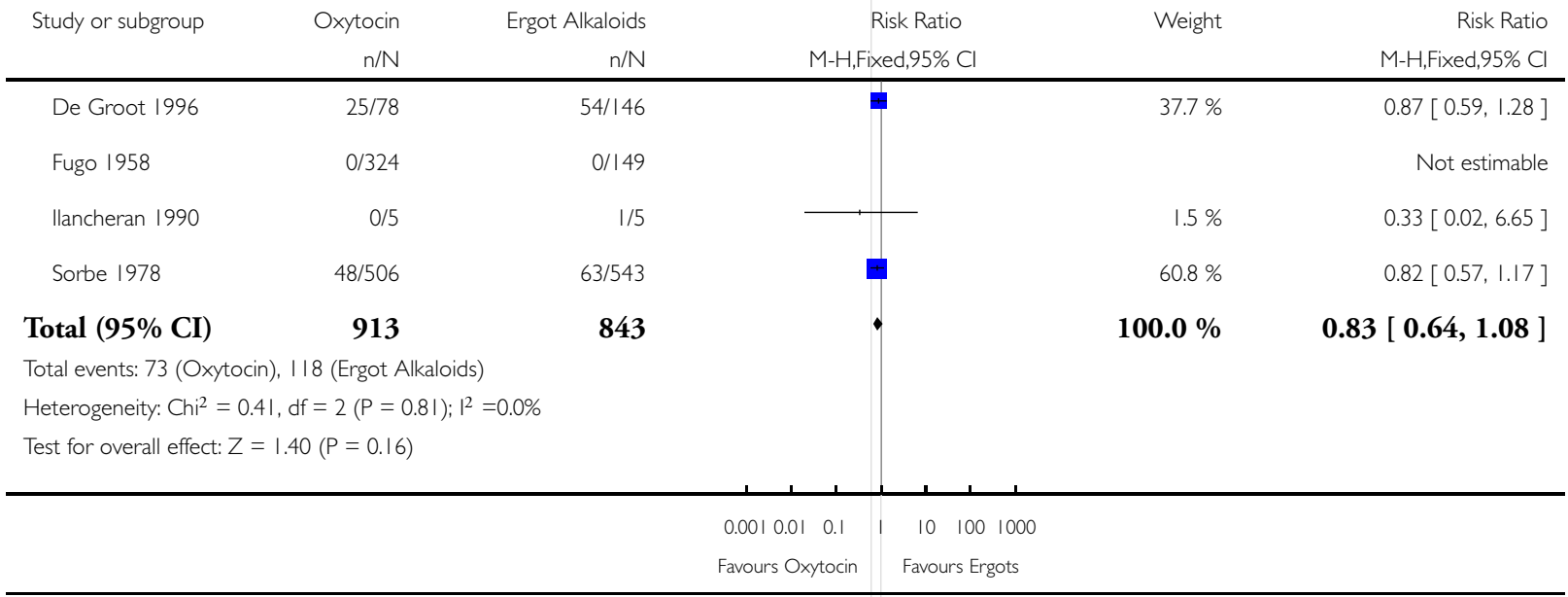

Prophylactic oxytocin for the third stage of labour (Review)

Copyright $\odot 2010$ The Cochrane Collaboration. Published by John Wiley \& Sons, Ltd. 


\section{Analysis I I.2. Comparison I I Oxytocin versus ergot alkaloids (given before placental delivery), Outcome 2}

Severe PPH (clinically estimated blood loss $>$ or $=1000 \mathrm{ml})$.

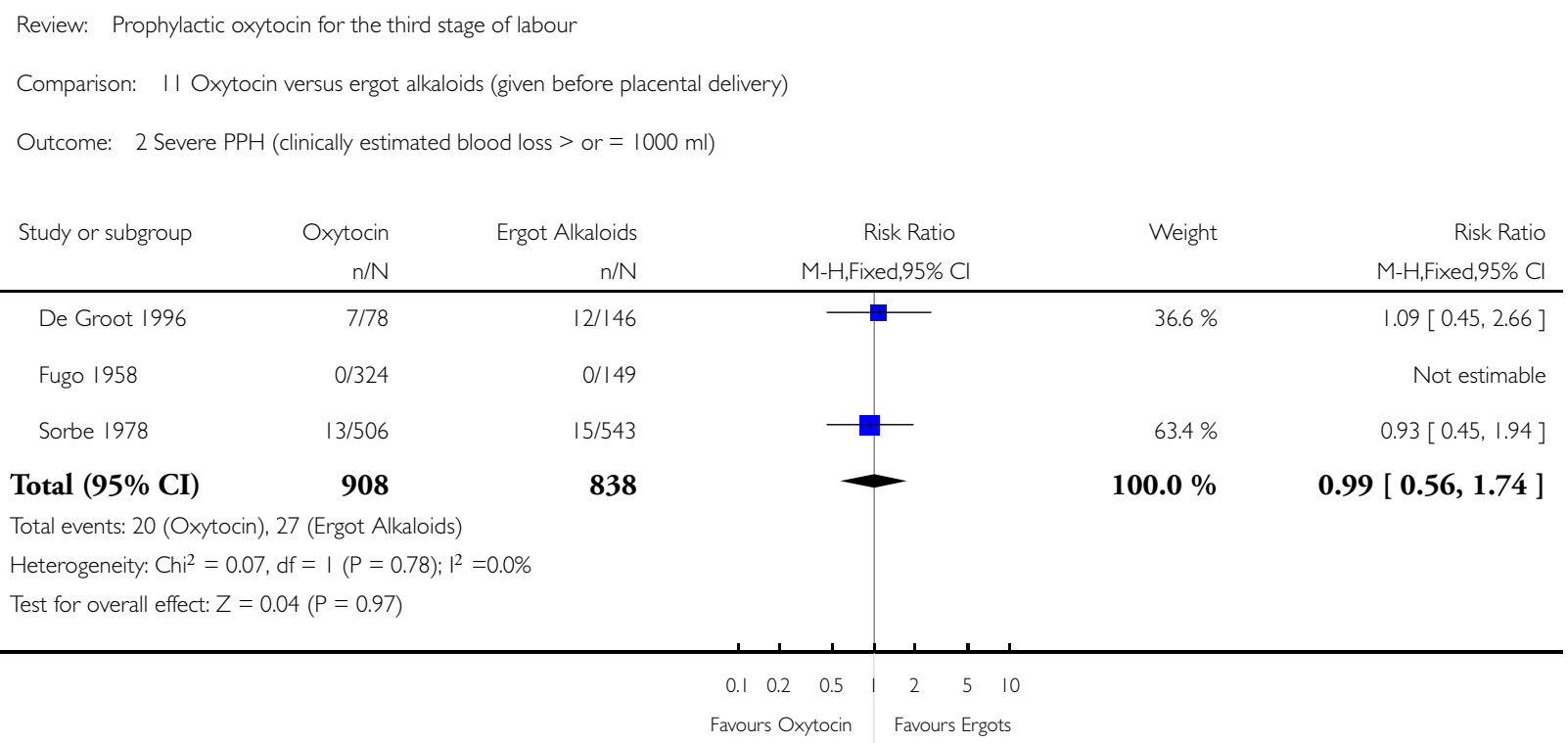


Analysis II.3. Comparison II Oxytocin versus ergot alkaloids (given before placental delivery), Outcome 3 Mean blood loss ( $\mathrm{ml})$.

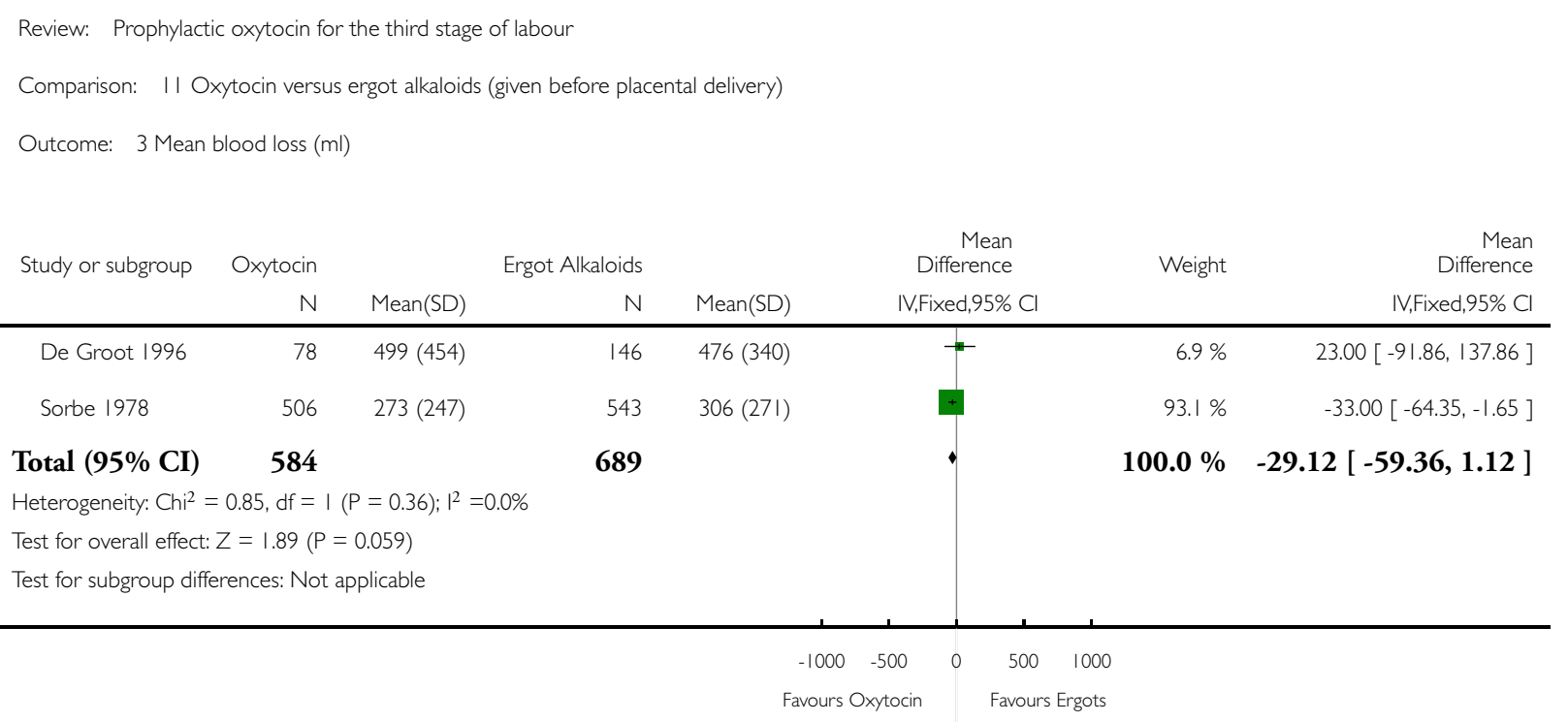

\section{Analysis I I.5. Comparison I I Oxytocin versus ergot alkaloids (given before placental delivery), Outcome 5 Blood transfusion.}

Review: Prophylactic oxytocin for the third stage of labour

Comparison: II Oxytocin versus ergot alkaloids (given before placental delivery)

Outcome: 5 Blood transfusion

\begin{tabular}{|c|c|c|c|c|c|}
\hline \multirow[t]{2}{*}{ Study or subgroup } & Oxytocin & Ergot Alkaloids & Risk Ratio & Weight & Risk Ratio \\
\hline & $n / N$ & $\mathrm{n} / \mathrm{N}$ & M-H,Fixed,95\% Cl & & M-H,Fixed,95\% Cl \\
\hline De Groot 1996 & $2 / 78$ & $1 / 146$ & +5 & $100.0 \%$ & $3.74[0.34,40.64]$ \\
\hline Total $(95 \% \mathrm{CI})$ & 78 & 146 & {[} & $100.0 \%$ & $3.74[0.34,40.64]$ \\
\hline \multicolumn{6}{|c|}{ Total events: 2 (Oxytocin), I (Ergot Alkaloids) } \\
\hline \multicolumn{6}{|c|}{ Heterogeneity: not applicable } \\
\hline \multicolumn{6}{|c|}{ Test for overall effect: $Z=1.08(P=0.28)$} \\
\hline
\end{tabular}


Analysis II.7. Comparison II Oxytocin versus ergot alkaloids (given before placental delivery), Outcome 7 Therapeutic uterontonics.

\begin{tabular}{|c|c|c|c|c|c|}
\hline \multicolumn{6}{|c|}{ Comparison: II Oxytocin versus ergot alkaloids (given before placental delivery) } \\
\hline \multicolumn{6}{|c|}{ Outcome: 7 Therapeutic uterontonics } \\
\hline \multirow[t]{2}{*}{ Study or subgroup } & Oxytocin & Ergot Alkaloids & Risk Ratio & Weight & Risk Ratio \\
\hline & $n / N$ & $n / N$ & M-H,Fixed,95\% Cl & & M-H,Fixed,95\% Cl \\
\hline De Groot 1996 & $14 / 78$ & $21 / 146$ & 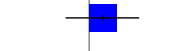 & $100.0 \%$ & $1.25[0.67,2.31]$ \\
\hline Total $(95 \% \mathrm{CI})$ & 78 & 146 & & $100.0 \%$ & $1.25[0.67,2.31]$ \\
\hline \multicolumn{6}{|c|}{ Total events: 14 (Oxytocin), 21 (Ergot Alkaloids) } \\
\hline \multicolumn{6}{|c|}{ Heterogeneity: not applicable } \\
\hline \multicolumn{6}{|c|}{ Test for overall effect: $Z=0.70(P=0.48)$} \\
\hline
\end{tabular}

\section{Analysis I I.8. Comparison I I Oxytocin versus ergot alkaloids (given before placental delivery), Outcome 8} Third stage $>20$ minutes.

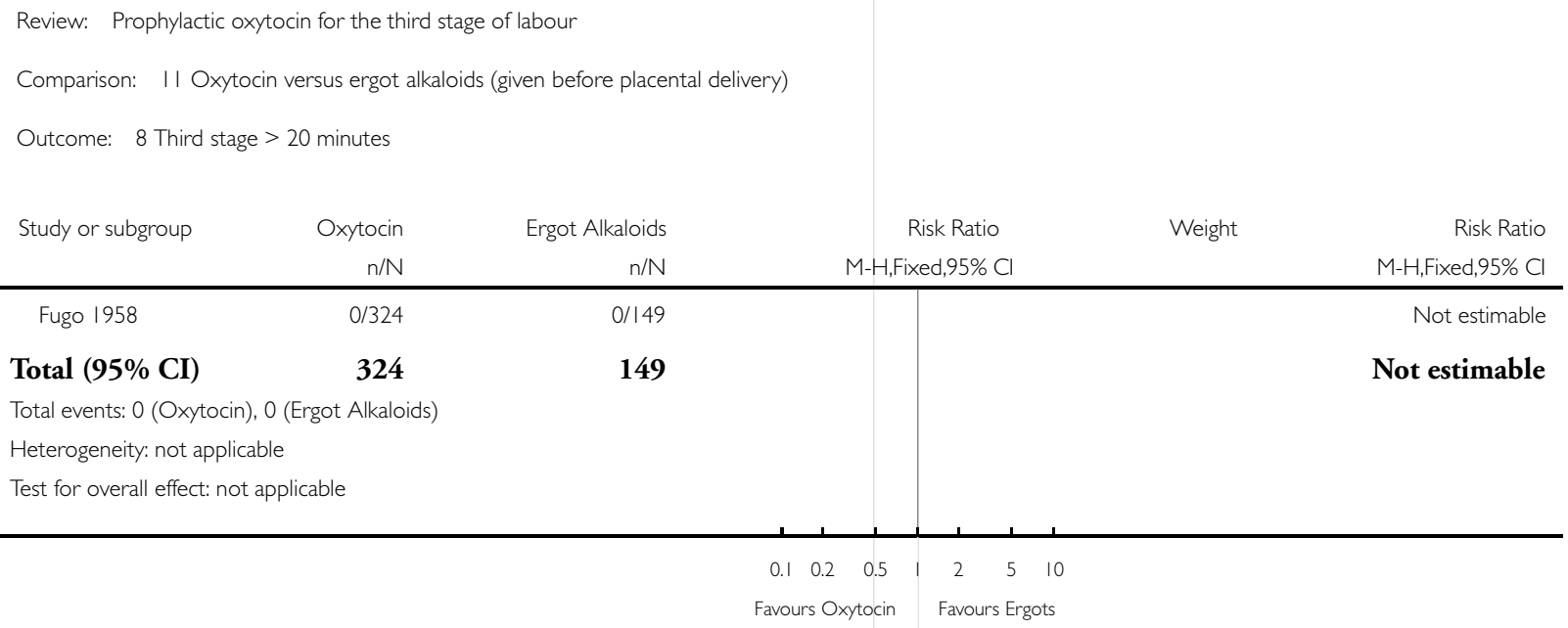


Analysis II.9. Comparison I I Oxytocin versus ergot alkaloids (given before placental delivery), Outcome 9 Third stage $>\mathbf{4 0}$ minutes.

\begin{tabular}{|c|c|c|c|c|c|}
\hline \multicolumn{6}{|c|}{ Comparison: II Oxytocin versus ergot alkaloids (given before placental delivery) } \\
\hline \multicolumn{6}{|c|}{ Outcome: 9 Third stage $>40$ minutes } \\
\hline \multirow[t]{2}{*}{ Study or subgroup } & Oxytocin & Ergot Alkaloids & Risk Ratio & \multirow[t]{2}{*}{ Weight } & Risk Ratio \\
\hline & $\mathrm{n} / \mathrm{N}$ & $\mathrm{n} / \mathrm{N}$ & M-H,Fixed,95\% Cl & & M-H,Fixed,95\% Cl \\
\hline Fugo 1958 & $0 / 324$ & $0 / 149$ & & & Not estimable \\
\hline Total $(95 \% \mathrm{CI})$ & 324 & 149 & & & Not estimable \\
\hline \multicolumn{6}{|c|}{ Total events: 0 (Oxytocin), 0 (Ergot Alkaloids) } \\
\hline \multicolumn{6}{|c|}{ Heterogeneity: not applicable } \\
\hline \multicolumn{6}{|c|}{ Test for overall effect: not applicable } \\
\hline
\end{tabular}

\section{Analysis I I.10. Comparison I I Oxytocin versus ergot alkaloids (given before placental delivery), Outcome} 10 Mean length of third stage (minutes).

Review: Prophylactic oxytocin for the third stage of labour

Comparison: II Oxytocin versus ergot alkaloids (given before placental delivery)

Outcome: 10 Mean length of third stage (minutes)

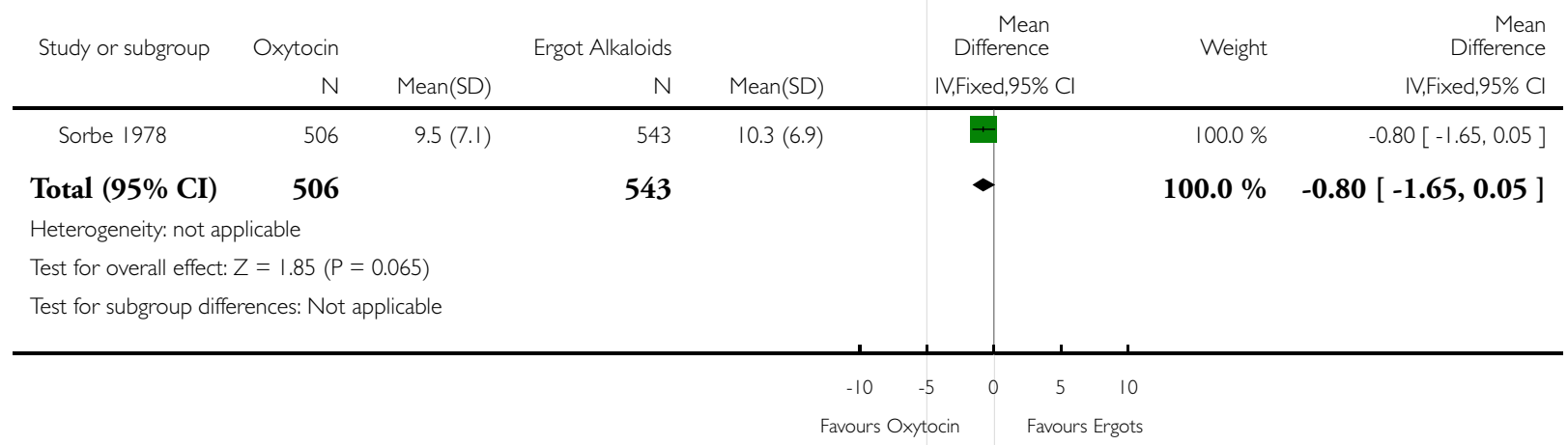


Analysis II.I I. Comparison I I Oxytocin versus ergot alkaloids (given before placental delivery), Outcome I I Manual removal of the placenta.

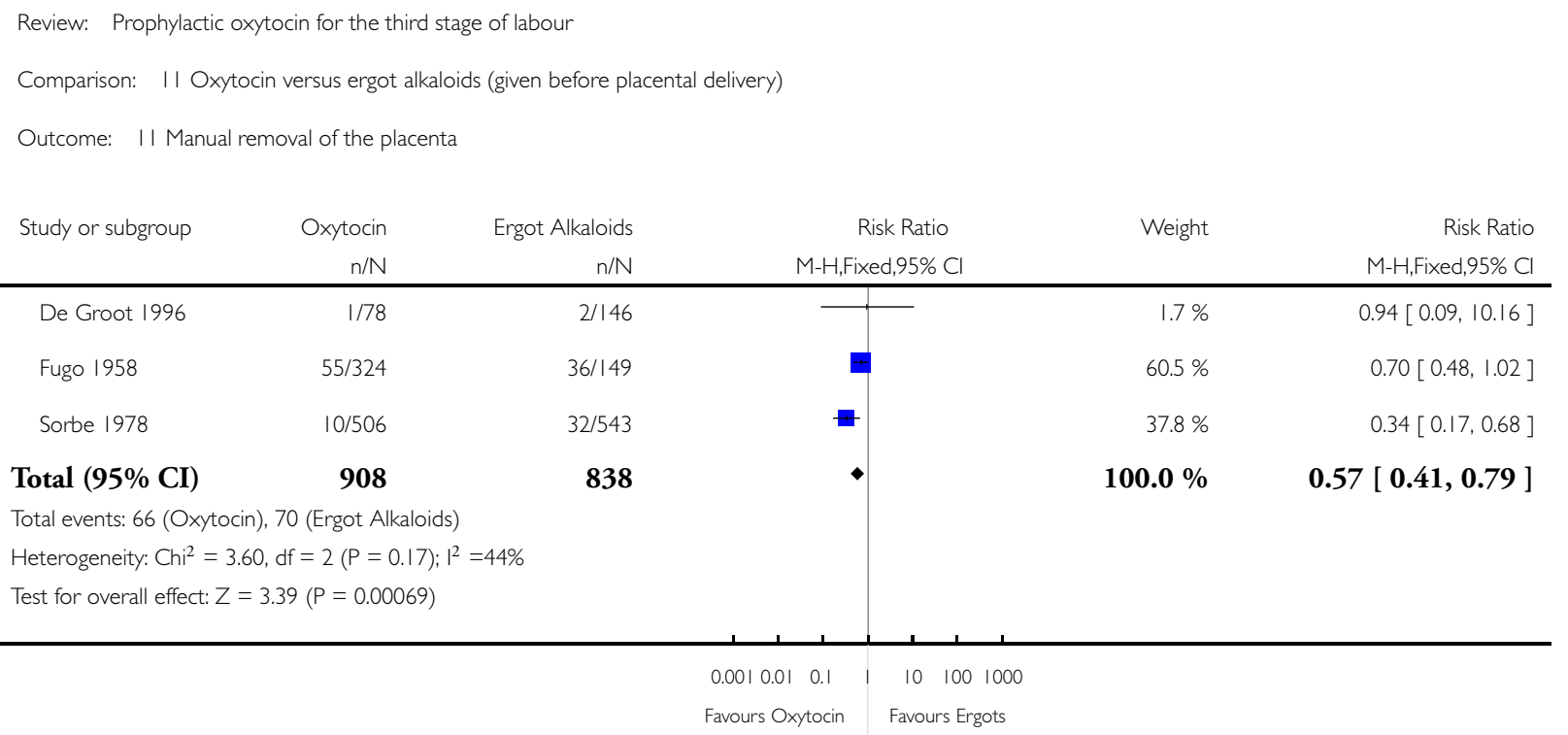

Analysis I I.I3. Comparison II Oxytocin versus ergot alkaloids (given before placental delivery), Outcome 13 Diastolic blood pressure > $100 \mathrm{~mm} \mathrm{Hg}$ between delivery of the baby and discharge from the labour ward.

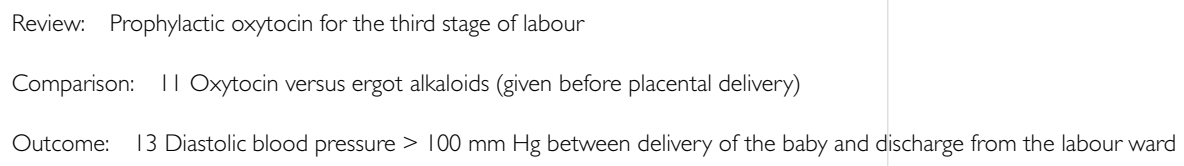

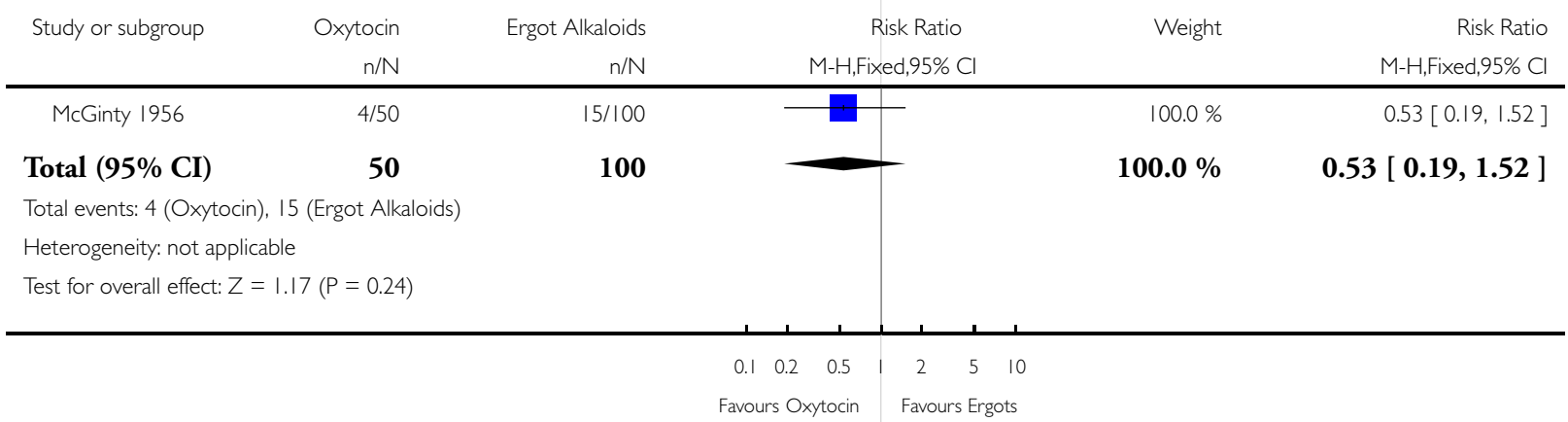


Analysis I2.I. Comparison I2 Oxytocin versus ergot alkaloids (given after placental delivery), Outcome I PPH (clinically estimated blood loss $>$ or $=500 \mathrm{ml}$ ).

\begin{tabular}{|c|c|c|c|c|c|}
\hline \multicolumn{6}{|c|}{ Comparison: 12 Oxytocin versus ergot alkaloids (given after placental delivery) } \\
\hline \multicolumn{6}{|c|}{ Outcome: I PPH (clinically estimated blood loss $>$ or $=500 \mathrm{ml}$ ) } \\
\hline \multirow[t]{2}{*}{ Study or subgroup } & Oxytocin & Ergot Alkaloids & Risk Ratio & Weight & Risk Ratio \\
\hline & $\mathrm{n} / \mathrm{N}$ & $\mathrm{n} / \mathrm{N}$ & $\mathrm{M}-\mathrm{H}, \mathrm{Fixed}, 95 \% \mathrm{Cl}$ & & M-H,Fixed,95\% Cl \\
\hline Howard 1964 & $15 / 470$ & 9/493 & + & $100.0 \%$ & $1.75[0.77,3.96]$ \\
\hline Total $(95 \% \mathrm{CI})$ & 470 & 493 & & $100.0 \%$ & $1.75[0.77,3.96]$ \\
\hline \multicolumn{6}{|c|}{ Total events: I5 (Oxytocin), 9 (Ergot Alkaloids) } \\
\hline \multicolumn{6}{|c|}{ Heterogeneity: not applicable } \\
\hline \multicolumn{6}{|c|}{ Test for overall effect: $Z=1.34(P=0.18)$} \\
\hline
\end{tabular}

\section{Analysis 12.7. Comparison 12 Oxytocin versus ergot alkaloids (given after placental delivery), Outcome 7} Therapeutic uterontonics.

\begin{tabular}{|c|c|c|c|c|c|}
\hline \multicolumn{6}{|c|}{ Comparison: 12 Oxytocin versus ergot alkaloids (given after placental delivery) } \\
\hline \multicolumn{6}{|c|}{ Outcome: 7 Therapeutic uterontonics } \\
\hline \multirow[t]{2}{*}{ Study or subgroup } & Oxytocin & Ergot Alkaloids & Risk Ratio & Weight & Risk Ratio \\
\hline & $\mathrm{n} / \mathrm{N}$ & $n / N$ & M-H,Fixed, $95 \% \mathrm{Cl}$ & & M-H,Fixed, $95 \% \mathrm{Cl}$ \\
\hline Howard 1964 & $21 / 479$ & $25 / 505$ & & $100.0 \%$ & $0.89[0.50,1.56]$ \\
\hline Total $(95 \% \mathrm{CI})$ & 479 & 505 & - & $100.0 \%$ & $0.89[0.50,1.56]$ \\
\hline \multicolumn{6}{|c|}{ Total events: 21 (Oxytocin), 25 (Ergot Alkaloids) } \\
\hline \multicolumn{6}{|c|}{ Heterogeneity: not applicable } \\
\hline \multicolumn{6}{|c|}{ Test for overall effect: $Z=0.42(P=0.67)$} \\
\hline
\end{tabular}


Analysis 13.I. Comparison I3 Oxytocin + ergometrine versus ergot alkaloids alone (all trials), Outcome I PPH (clinically estimated blood loss $>$ or $=500 \mathrm{ml}$ ).

\begin{tabular}{|c|c|c|c|c|c|}
\hline \multicolumn{6}{|c|}{ Comparison: 13 Oxytocin + ergometrine versus ergot alkaloids alone (all trials) } \\
\hline \multicolumn{6}{|c|}{ Outcome: I PPH (clinically estimated blood loss $>$ or $=500 \mathrm{ml}$ ) } \\
\hline \multirow[t]{2}{*}{ Study or subgroup } & Syntometrine & Ergot Alkaloids & Risk Ratio & Weight & \multirow{2}{*}{$\begin{array}{r}\text { Risk Ratio } \\
\text { M-H,Fixed,95\% Cl }\end{array}$} \\
\hline & $\mathrm{n} / \mathrm{N}$ & $\mathrm{n} / \mathrm{N}$ & M-H,Fixed,95\% Cl & & \\
\hline Barbaro $|96|$ & $39 / 300$ & $10 / 300$ & + & $19.3 \%$ & $3.90[1.98,7.67]$ \\
\hline Bonham 1963 & $5 / 391$ & $13 / 416$ & $\rightarrow$ & $24.3 \%$ & $0.41[0.15,1.14]$ \\
\hline Francis (2) 1965a & $4 / 171$ & $9 / 183$ & $\rightarrow$ & $16.8 \%$ & $0.48[0.15,1.52]$ \\
\hline llancheran 1990 & $0 / 5$ & $1 / 5$ & \begin{tabular}{l|l}
$\cdot$
\end{tabular} & $2.9 \%$ & $0.33[0.02,6.65]$ \\
\hline Soiva 1964 & $18 / 560$ & $19 / 560$ & 典 & $36.7 \%$ & $0.95[0.50,1.79]$ \\
\hline Total $(95 \% \mathrm{CI})$ & 1427 & 1464 & $\bullet$ & $100.0 \%$ & $1.29[0.90,1.84]$ \\
\hline \multicolumn{6}{|c|}{ Total events: 66 (Syntometrine), 52 (Ergot Alkaloids) } \\
\hline \multicolumn{6}{|c|}{ Heterogeneity: $\mathrm{Ch}^{2}=19.68, \mathrm{df}=4(P=0.00058) ; I^{2}=80 \%$} \\
\hline \multicolumn{6}{|c|}{ Test for overall effect: $Z=1.40(P=0.16)$} \\
\hline
\end{tabular}

\section{Analysis 13.2. Comparison 13 Oxytocin + ergometrine versus ergot alkaloids alone (all trials), Outcome 2} Severe PPH (clinically estimated blood loss $>$ or $=1000 \mathrm{ml})$.

Review: Prophylactic oxytocin for the third stage of labour

Comparison: 13 Oxytocin + ergometrine versus ergot alkaloids alone (all trials)

Outcome: 2 Severe PPH (clinically estimated blood loss $>$ or $=1000 \mathrm{ml}$ )

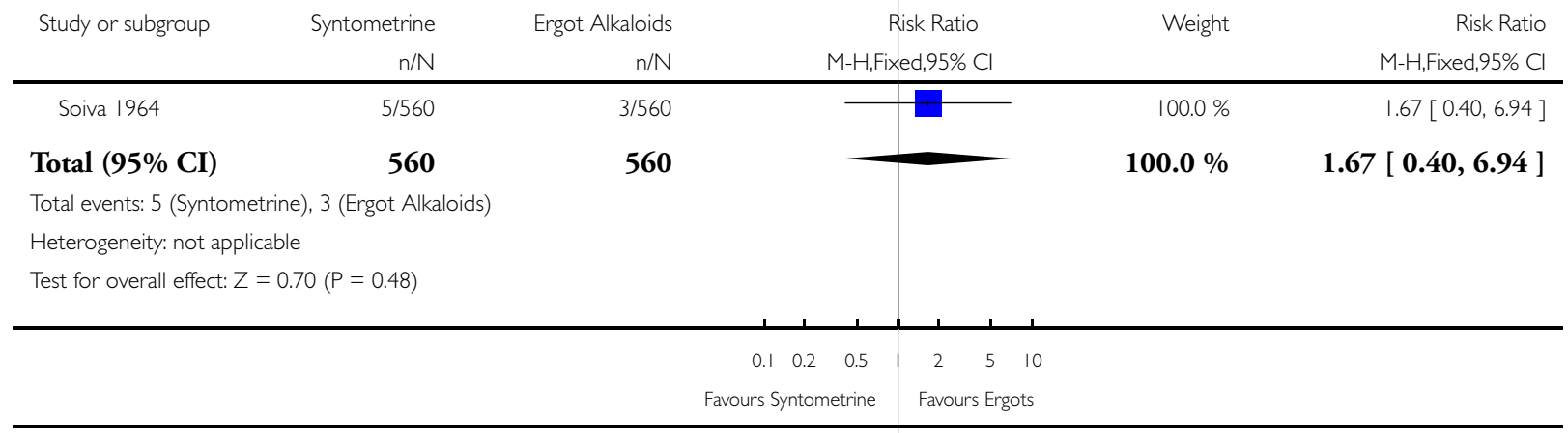

Prophylactic oxytocin for the third stage of labour (Review)

Copyright () 2010 The Cochrane Collaboration. Published by John Wiley \& Sons, Ltd. 
Analysis 13.5. Comparison 13 Oxytocin + ergometrine versus ergot alkaloids alone (all trials), Outcome 5 Blood transfusion.

\begin{tabular}{|c|c|c|c|c|c|}
\hline \multicolumn{6}{|c|}{ Comparison: 13 Oxytocin + ergometrine versus ergot alkaloids alone (all trials) } \\
\hline \multicolumn{6}{|c|}{ Outcome: 5 Blood transfusion } \\
\hline \multirow[t]{2}{*}{ Study or subgroup } & Syntometrine & Ergot Alkaloids & Risk Ratio & Weight & Risk Ratio \\
\hline & $\mathrm{n} / \mathrm{N}$ & $\mathrm{n} / \mathrm{N}$ & M-H,Fixed,95\% Cl & & M-H,Fixed,95\% Cl \\
\hline Soiva 1964 & $5 / 560$ & $7 / 560$ & \begin{tabular}{c|c}
$1+1$ \\
+10
\end{tabular} & $100.0 \%$ & $0.71[0.23,2.24]$ \\
\hline Total (95\% CI) & 560 & 560 & & $100.0 \%$ & $0.71[0.23,2.24]$ \\
\hline \multicolumn{6}{|c|}{ Total events: 5 (Syntometrine), 7 (Ergot Alkaloids) } \\
\hline \multicolumn{6}{|c|}{ Heterogeneity: not applicable } \\
\hline \multicolumn{6}{|c|}{ Test for overall effect: $Z=0.58(P=0.56)$} \\
\hline
\end{tabular}


Analysis 13.8. Comparison 13 Oxytocin + ergometrine versus ergot alkaloids alone (all trials), Outcome 8 Third stage $>20$ minutes.

\begin{tabular}{|c|c|c|c|c|c|}
\hline \multicolumn{6}{|c|}{ Comparison: 13 Oxytocin + ergometrine versus ergot alkaloids alone (all trials) } \\
\hline \multicolumn{6}{|c|}{ Outcome: 8 Third stage $>20$ minutes } \\
\hline \multirow[t]{2}{*}{ Study or subgroup } & Syntometrine & Ergot Alkaloids & Risk Ratio & Weight & Risk Ratio \\
\hline & $\mathrm{n} / \mathrm{N}$ & $\mathrm{n} / \mathrm{N}$ & M-H,Fixed,95\% Cl & & M-H,Fixed,95\% Cl \\
\hline Bonham 1963 & $|0 / 39|$ & $7 / 416$ & - & $7.6 \%$ & $1.52[0.58,3.95]$ \\
\hline Francis (2) 1965 a & $3 / 171$ & $1 / 183$ & 7 & $1.1 \%$ & $3.21[0.34,30.57]$ \\
\hline Soiva 1964 & $66 / 560$ & $81 / 560$ & + & $91.3 \%$ & $0.81[0.60,1.10]$ \\
\hline Total $(95 \% \mathrm{CI})$ & 1122 & 1159 & • & $100.0 \%$ & $0.89[0.67,1.19]$ \\
\hline \multicolumn{6}{|c|}{ Total events: 79 (Syntometrine), 89 (Ergot Alkaloids) } \\
\hline \multicolumn{6}{|c|}{ Heterogeneity: $\mathrm{Chi}^{2}=2.78, \mathrm{df}=2(\mathrm{P}=0.25) ; \mathrm{I}^{2}=28 \%$} \\
\hline \multicolumn{6}{|c|}{ Test for overall effect: $Z=0.77(P=0.44)$} \\
\hline
\end{tabular}

\section{Analysis 13.II. Comparison 13 Oxytocin + ergometrine versus ergot alkaloids alone (all trials), Outcome I I Manual removal of the placenta.}

Review: Prophylactic oxytocin for the third stage of labour

Comparison: 13 Oxytocin + ergometrine versus ergot alkaloids alone (all trials)

Outcome: II Manual removal of the placenta

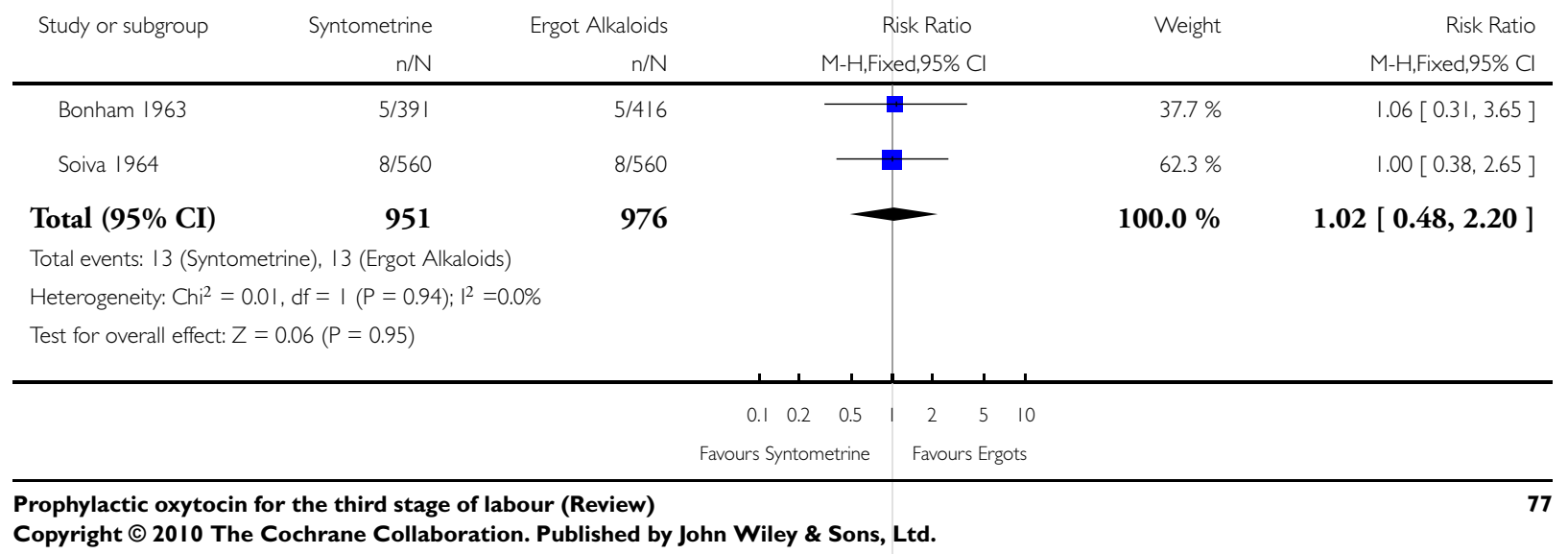


Analysis I4.I. Comparison I4 Oxytocin + ergometrine versus ergot alkaloids alone (randomised trials), Outcome I PPH (clinically estimated blood loss $>$ or $=500 \mathrm{ml}$ ).

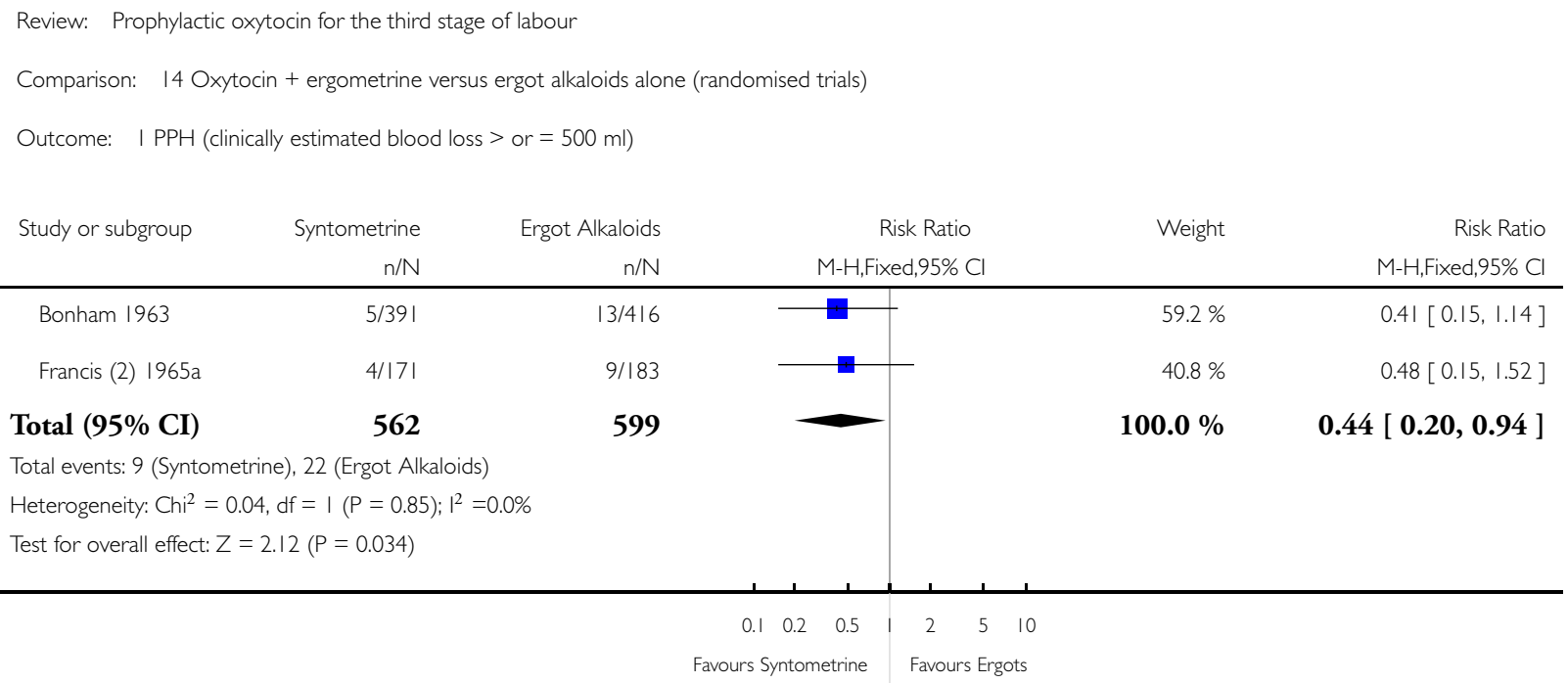


Analysis 14.8. Comparison 14 Oxytocin + ergometrine versus ergot alkaloids alone (randomised trials), Outcome 8 Third stage $>20$ minutes.

\begin{tabular}{|c|c|c|c|c|c|}
\hline \multicolumn{6}{|c|}{ Comparison: 14 Oxytocin + ergometrine versus ergot alkaloids alone (randomised trials) } \\
\hline \multicolumn{6}{|c|}{ Outcome: 8 Third stage $>20$ minutes } \\
\hline \multirow[t]{2}{*}{ Study or subgroup } & Syntometrine & Ergot Alkaloids & Risk Ratio & Weight & Risk Ratio \\
\hline & $\mathrm{n} / \mathrm{N}$ & $\mathrm{n} / \mathrm{N}$ & M-H,Fixed,95\% Cl & & M-H,Fixed,95\% Cl \\
\hline Francis (2) $1965 a$ & $3 / 171$ & $1 / 183$ & + & $100.0 \%$ & $3.21[0.34,30.57]$ \\
\hline Total $(95 \% \mathrm{CI})$ & 171 & 183 & 2 & $100.0 \%$ & $3.21[0.34,30.57]$ \\
\hline \multicolumn{6}{|c|}{ Total events: 3 (Syntometrine), I (Ergot Alkaloids) } \\
\hline \multicolumn{6}{|c|}{ Heterogeneity: not applicable } \\
\hline \multicolumn{6}{|c|}{ Test for overall effect: $Z=1.01(P=0.31)$} \\
\hline
\end{tabular}

\section{Analysis I5.I. Comparison I5 Oxytocin + ergometrine versus ergot alkaloids alone (active management), Outcome I PPH (clinically estimated blood loss $>$ or $=500 \mathrm{ml}$ ).}

\begin{tabular}{|c|c|c|c|c|c|}
\hline \multicolumn{6}{|c|}{ Comparison: 15 Oxytocin + ergometrine versus ergot alkaloids alone (active management) } \\
\hline \multicolumn{6}{|c|}{ Outcome: I PPH (clinically estimated blood loss $>$ or $=500 \mathrm{ml}$ ) } \\
\hline \multirow[t]{2}{*}{ Study or subgroup } & Syntometrine & Ergot Alkaloids & Risk Ratio & Weight & Risk Ratio \\
\hline & $\mathrm{n} / \mathrm{N}$ & $\mathrm{n} / \mathrm{N}$ & M-H,Fixed,95\% Cl & & M-H,Fixed,95\% Cl \\
\hline Bonham 1963 & $1 / 199$ & $5 / 217$ & $\longrightarrow$ & $100.0 \%$ & $0.22[0.03,1.85]$ \\
\hline Total (95\% CI) & 199 & 217 & & $100.0 \%$ & $0.22[0.03,1.85]$ \\
\hline \multicolumn{6}{|c|}{ Total events: I (Syntometrine), 5 (Ergot Alkaloids) } \\
\hline \multicolumn{6}{|c|}{ Heterogeneity: not applicable } \\
\hline \multicolumn{6}{|c|}{ Test for overall effect: $Z=1.40(P=0.16)$} \\
\hline
\end{tabular}


Analysis 15.8. Comparison 15 Oxytocin + ergometrine versus ergot alkaloids alone (active management), Outcome 8 Third stage $>20$ minutes.

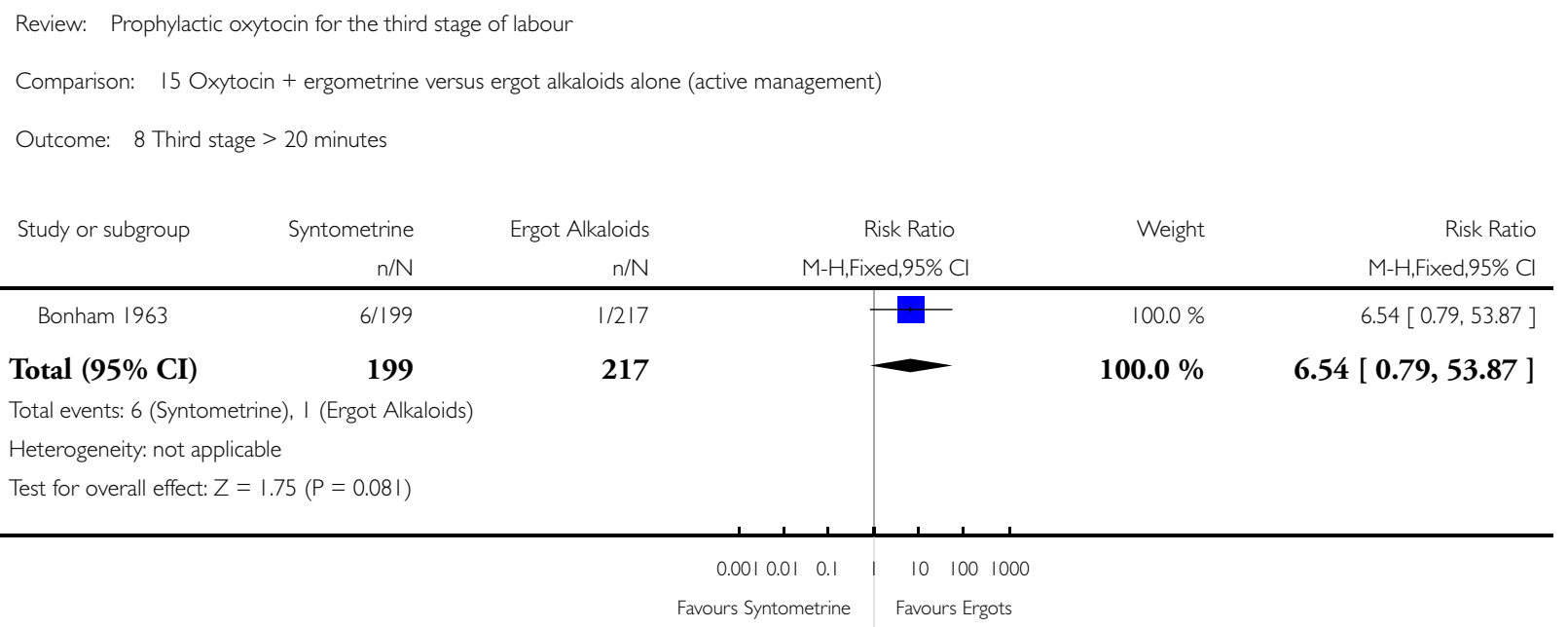

\section{Analysis I5.II. Comparison 15 Oxytocin + ergometrine versus ergot alkaloids alone (active management),} Outcome I I Manual removal of the placenta.

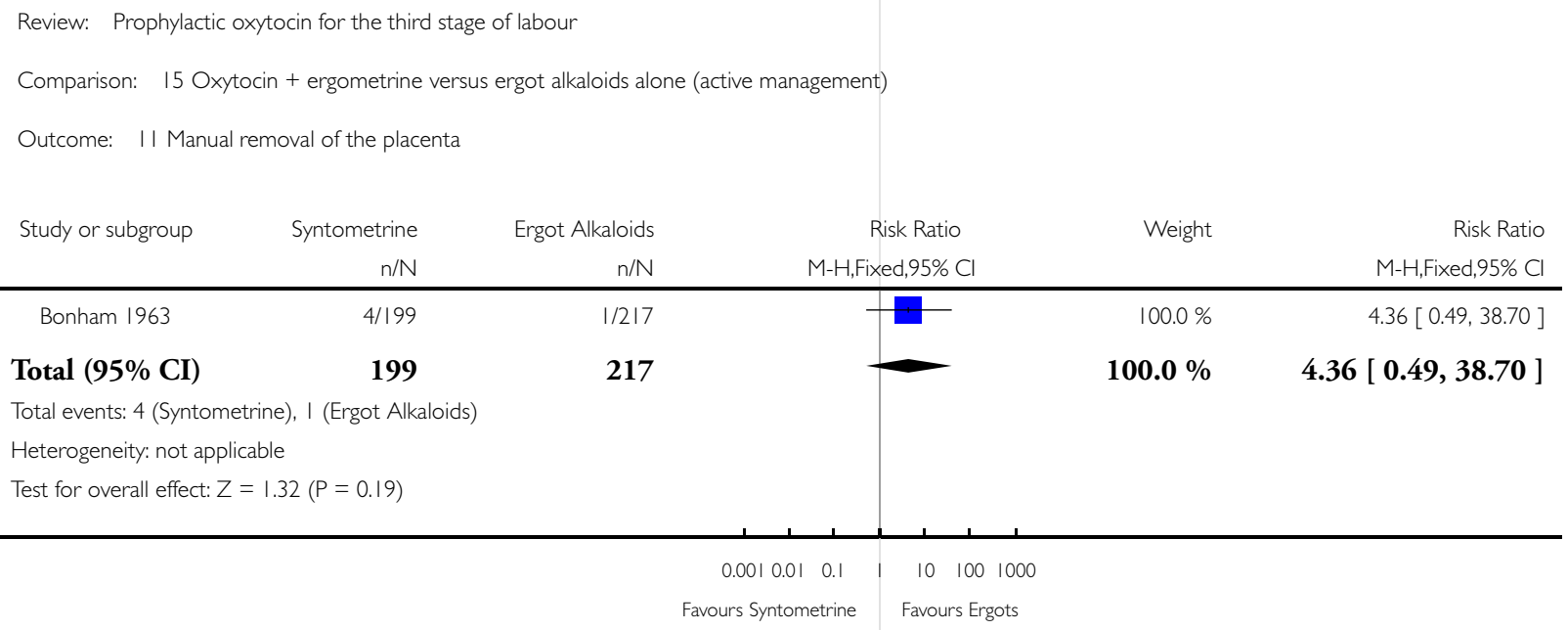




\section{Analysis 17.I. Comparison 17 Oxytocin + ergometrine versus ergot alkaloids alone (given before placental delivery, Outcome I PPH (clinically estimated blood loss $>$ or $=500 \mathrm{ml}$ ).}

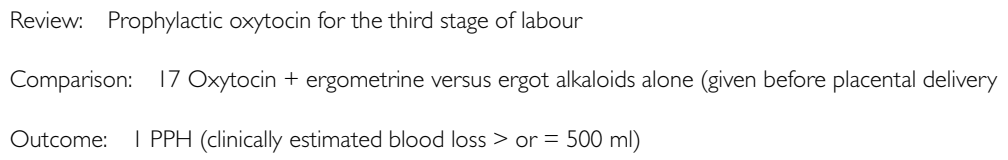

\begin{tabular}{|c|c|c|c|c|c|}
\hline \multirow[t]{2}{*}{ Study or subgroup } & \multirow{2}{*}{$\begin{array}{r}\text { Syntometrine } \\
n / N\end{array}$} & \multirow{2}{*}{$\begin{array}{r}\text { Ergot Alkaloids } \\
n / N\end{array}$} & Risk Ratio & \multirow[t]{2}{*}{ Weight } & \multirow{2}{*}{$\begin{array}{r}\text { Risk Ratio } \\
\text { M-H,Fixed,95\% Cl }\end{array}$} \\
\hline & & & M-H,Fixed,95\% Cl & & \\
\hline Barbaro 1961 & $39 / 300$ & $10 / 300$ & 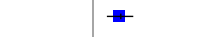 & $19.3 \%$ & $3.90[1.98,7.67]$ \\
\hline Bonham 1963 & $5 / 391$ & $13 / 4 \mid 6$ & $\rightarrow$ & $24.3 \%$ & $0.41[0.15,1.14]$ \\
\hline Francis (2) 1965a & $4 / 171$ & $9 / 183$ & $\rightarrow$ & $16.8 \%$ & $0.48[0.15,1.52]$ \\
\hline Ilancheran 1990 & $0 / 5$ & $1 / 5$ & & $2.9 \%$ & $0.33[0.02,6.65]$ \\
\hline Soiva 1964 & $18 / 560$ & $19 / 560$ & & $36.7 \%$ & $0.95[0.50,1.79]$ \\
\hline Total (95\% CI) & 1427 & 1464 & $\bullet$ & $100.0 \%$ & $1.29[0.90,1.84]$ \\
\hline \multicolumn{6}{|c|}{ Total events: 66 (Syntometrine), 52 (Ergot Alkaloids) } \\
\hline \multicolumn{6}{|c|}{ Heterogeneity: Chi $^{2}=19.68, d f=4(P=0.00058) ;\left.\right|^{2}=80 \%$} \\
\hline \multicolumn{6}{|c|}{ Test for overall effect: $Z=1.40(P=0.16)$} \\
\hline
\end{tabular}

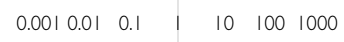

Favours Syntometrine Favours Ergots

Analysis 17.2. Comparison 17 Oxytocin + ergometrine versus ergot alkaloids alone (given before placental delivery, Outcome 2 Severe PPH (clinically estimated blood loss $>$ or $=1000 \mathrm{ml}$ ).

Review: Prophylactic oxytocin for the third stage of labour

Comparison: 17 Oxytocin + ergometrine versus ergot alkaloids alone (given before placental delivery

Outcome: 2 Severe PPH (clinically estimated blood loss $>$ or $=1000 \mathrm{ml}$ )

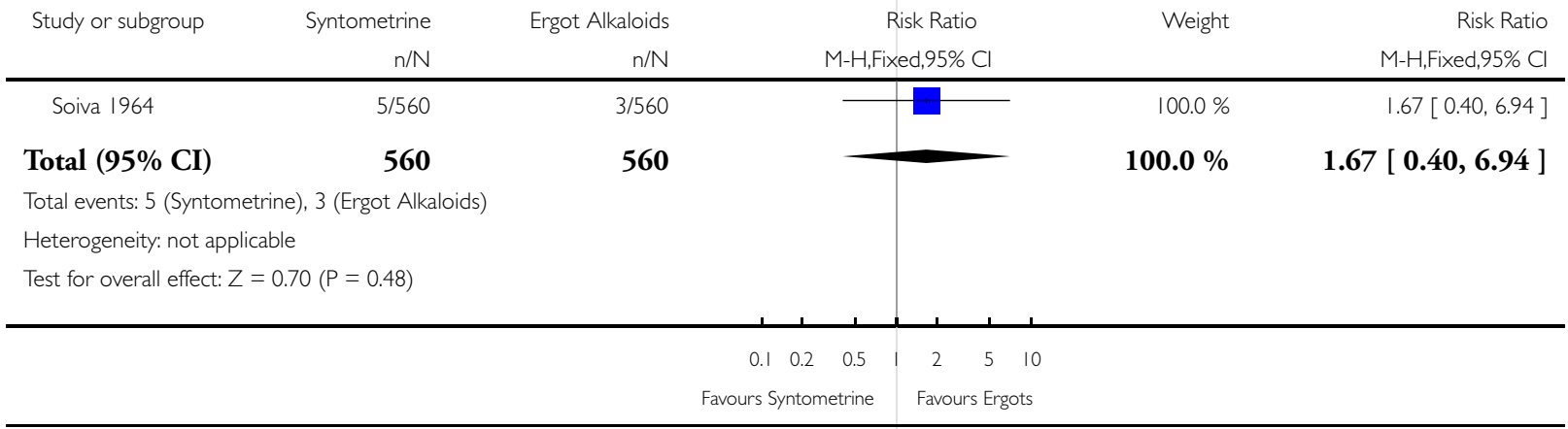

Prophylactic oxytocin for the third stage of labour (Review)

Copyright $\odot 2010$ The Cochrane Collaboration. Published by John Wiley \& Sons, Ltd. 
Analysis 17.5. Comparison 17 Oxytocin + ergometrine versus ergot alkaloids alone (given before placental delivery, Outcome 5 Blood transfusion.

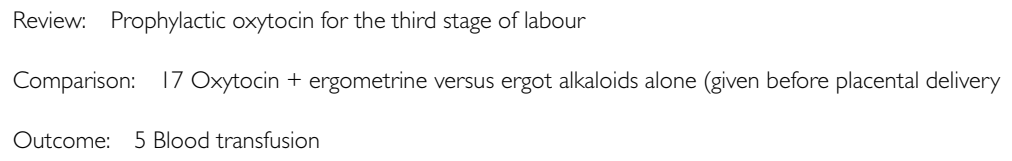

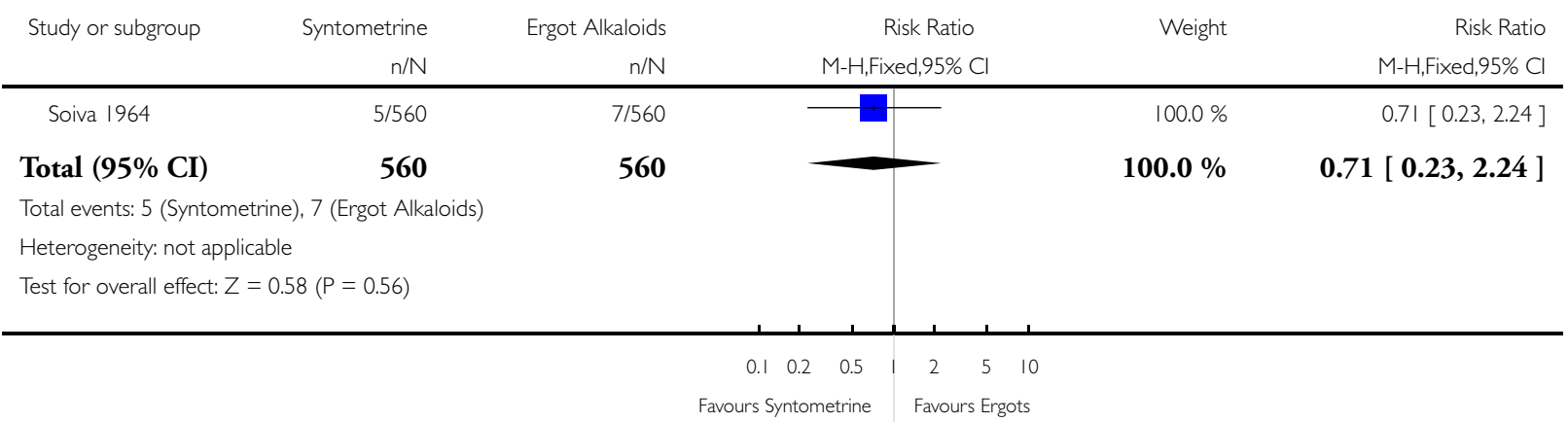


Analysis 17.8. Comparison 17 Oxytocin + ergometrine versus ergot alkaloids alone (given before placental delivery, Outcome 8 Third stage $>20$ minutes.

\begin{tabular}{|c|c|c|c|c|c|}
\hline \multicolumn{6}{|c|}{ Comparison: 17 Oxytocin + ergometrine versus ergot alkaloids alone (given before placental delivery } \\
\hline \multicolumn{6}{|c|}{ Outcome: 8 Third stage $>20$ minutes } \\
\hline \multirow[t]{2}{*}{ Study or subgroup } & Syntometrine & Ergot Alkaloids & Risk Ratio & Weight & Risk Ratio \\
\hline & $\mathrm{n} / \mathrm{N}$ & $\mathrm{n} / \mathrm{N}$ & M-H,Fixed,95\% Cl & & M-H,Fixed,95\% Cl \\
\hline Bonham 1963 & $|0 / 39|$ & $7 / 416$ & - & $7.6 \%$ & $1.52[0.58,3.95]$ \\
\hline Francis (2) 1965a & $3 / 171$ & 1//83 & +1 & $1.1 \%$ & $3.21[0.34,30.57]$ \\
\hline Soiva 1964 & $66 / 560$ & $81 / 560$ & + & $91.3 \%$ & $0.81[0.60,1.10]$ \\
\hline Total $(95 \%$ CI $)$ & 1122 & 1159 & $\bullet$ & $100.0 \%$ & $0.89[0.67,1.19]$ \\
\hline \multicolumn{6}{|c|}{ Total events: 79 (Syntometrine), 89 (Ergot Alkaloids) } \\
\hline \multicolumn{6}{|c|}{ Heterogeneity: $\mathrm{Chi}^{2}=2.78, \mathrm{df}=2(\mathrm{P}=0.25) ; \mathrm{I}^{2}=28 \%$} \\
\hline \multicolumn{6}{|c|}{ Test for overall effect: $Z=0.77(P=0.44)$} \\
\hline
\end{tabular}

Analysis 17.II. Comparison 17 Oxytocin + ergometrine versus ergot alkaloids alone (given before placental delivery, Outcome I I Manual removal of the placenta.

Review: Prophylactic oxytocin for the third stage of labour

Comparison: 17 Oxytocin + ergometrine versus ergot alkaloids alone (given before placental delivery

Outcome: II Manual removal of the placenta

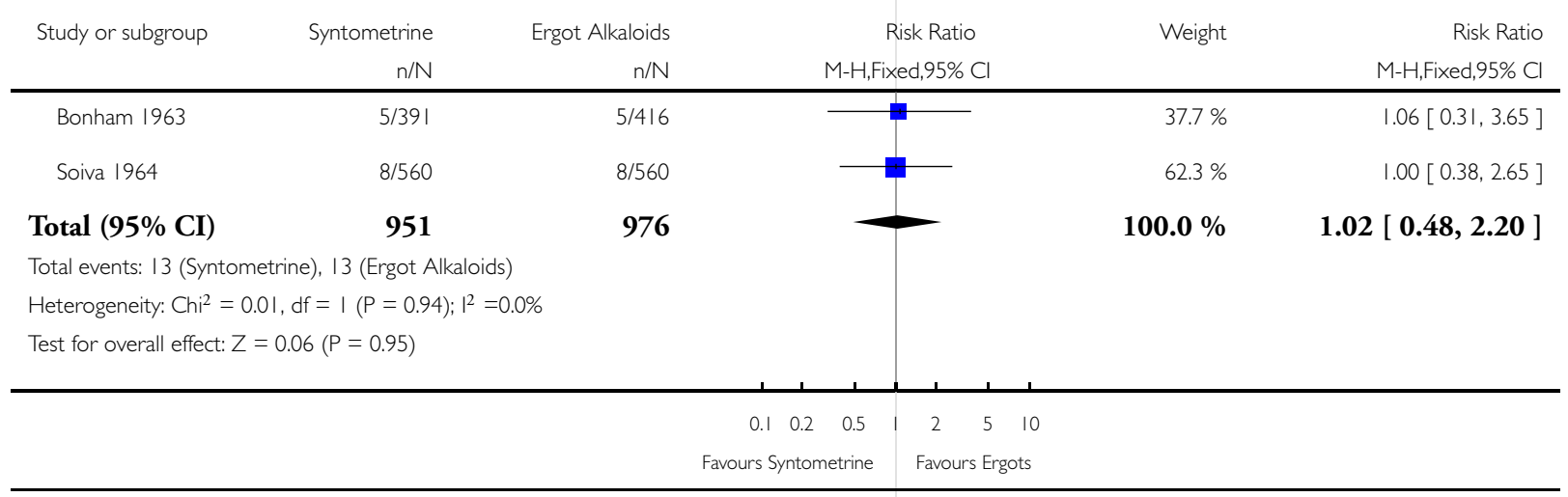

Prophylactic oxytocin for the third stage of labour (Review)

Copyright () 2010 The Cochrane Collaboration. Published by John Wiley \& Sons, Ltd. 


\section{F E E D B A C K}

\section{Pastrana, March 2007}

\section{Summary}

It is important to take care that the conclusions are based on pre-specified objectives, as sometimes the study is done and then the objectives decided afterwards.

In this review, there is no discussion of the way different studies determined blood loss, and the limitations of these methods. This is especially true for Pierre 1992. Also, the results should take into account Hoffman 2004, comparing oxytocin with expectant management. In this study, although the mean change in haematocrit was significantly less in the oxytocin group, there was no difference in the incidence of postpartum haemorrhage.

(Summary of comment from Jose Luis Pastrana, March 2007)

\section{Reply}

A reply from the authors will be published as soon as it is available.

\section{Contributors}

Feedback: Jose Luis Pastrana

\section{WHAT'S NEW}

Last assessed as up-to-date: 30 November 2004.

Date Event Description

1 October 2009 Amended Search updated. Ten reports added to Studies awaiting classification

\section{H I S T O R Y}

Protocol first published: Issue 4, 1999

Review first published: Issue 4, 2001 


\begin{tabular}{lll}
\hline Date & Event & Description \\
\hline 20 September 2008 & Amended & Converted to new review format. \\
\hline 1 March 2007 & Feedback has been incorporated & Feedback added from Pastrana, March 2007. \\
\hline 1 December 2004 & New search has been performed & $\begin{array}{l}\text { Search updated. We identified 16 new studies; however, none fulfilled the } \\
\text { inclusion criteria }\end{array}$ \\
\hline
\end{tabular}

\section{CONTRIBUTIONSOFAUTHORS}

The protocol was developed by Diana Elbourne, with Walter Prendiville and Sue McDonald. For the review, Diana Elbourne identified the potentially relevant papers. Diana Elbourne and Walter Prendiville independently extracted data from the papers, and compared and agreed the results. Diana Elbourne wrote the first draft of the text and revised it following comments from Guillermo Carroli, Juliet Wood, Walter Prendiville and Sue McDonald.

The December 2004 update was prepared by Amanda Cotter, Amen Ness and Jorge Tolosa, who independently assessed the new papers, compiled and agreed the results. Amanda Cotter and Jorge Tolosa reread the review and its objectives which they elected to keep.

\section{DECLARATIONSOF INTEREST}

None known.

\section{NOTES}

\section{Pastrana, March 2007}

\section{Summary}

It is important to take care that the conclusions are based on pre-specified objectives, as sometimes the study is done and then the objectives decided afterwards.

In this review, there is no discussion of the way different studies determined blood loss, and the limitations of these methods. This is especially true for Pierre 1992. Also, the results should take into account Hoffman 2004, comparing oxytocin with expectant management. In this study, although the mean change in haematocrit was significantly less in the oxytocin group, there was no difference in the incidence of postpartum haemorrhage.

(Summary of comment from Jose Luis Pastrana, March 2007)

\section{Reply}

A reply from the authors will be published as soon as it is available.ContributorsFeedback: Jose Luis Pastrana. 


\section{INDEX TERMS}

\section{Medical Subject Headings (MeSH)}

*Oxytocics; ${ }^{*}$ Oxytocin; Ergot Alkaloids; Labor Stage, Third [*drug effects]; Maternal Mortality; Postpartum Hemorrhage [mortality; *prevention \& control]

\section{MeSH check words}

Female; Humans; Pregnancy 